NBER WORKING PAPER SERIES

\title{
INTERNATIONAL TRANSMISSIONS OF MONETARY SHOCKS: BETWEEN A TRILEMMA AND A DILEMMA
}

\author{
Xuehui Han \\ Shang-Jin Wei \\ Working Paper 22812 \\ http://www.nber.org/papers/w22812 \\ NATIONAL BUREAU OF ECONOMIC RESEARCH \\ 1050 Massachusetts Avenue \\ Cambridge, MA 02138 \\ November 2016
}

The views expressed in this paper are those of the authors and do not necessarily reflect the views and policies of the Asian Development Bank (ADB), its Board of Governors, the governments they represent, or the National Bureau of Economic Research. The authors are grateful for excellent research assistance to Orlee P. Velarde, Lea R. Sumulong, and Nedelyn C. MagtibayRamos and for comments to Abdul D. Abiad, Joshua Aizenman, Atish R. Ghosh, Sebnem Kalemli Ozcan, Diwa Guinigundo, Arief Ramayandi, and participants of the research seminar at ADB, the Joint Central Bank of the Republic of Turkey - Bank of England Workshop on "The International Monetary and Financial System: short term challenges and long term solution," and the 7th Meeting of the International Policy Advisory Group. The authors are responsible for any remaining errors in the paper.

NBER working papers are circulated for discussion and comment purposes. They have not been peer-reviewed or been subject to the review by the NBER Board of Directors that accompanies official NBER publications.

(C) 2016 by Xuehui Han and Shang-Jin Wei. All rights reserved. Short sections of text, not to exceed two paragraphs, may be quoted without explicit permission provided that full credit, including $\odot$ notice, is given to the source. 
International Transmissions of Monetary Shocks: Between a Trilemma and a Dilemma

Xuehui Han and Shang-Jin Wei

NBER Working Paper No. 22812

November 2016

JEL No. F3

\begin{abstract}
$\underline{\text { ABSTRACT }}$
This paper re-examines international transmissions of monetary policy shocks from advanced economies to emerging market economies. In terms of methodologies, it combines three novel features. First, it separates co-movement in monetary policies due to common shocks from spillovers of monetary policies from advanced to peripheral economies. Second, it uses surprises in growth and inflation and the Taylor rule to gauge desired changes in a country's interest rate if it is to focus exclusively on growth, inflation, and real exchange rate stability. Third, it proposes a specification that can work with the quantitative easing episodes when no changes in US interest rate are observed. In terms of empirical findings, we differ from the existing literature and document patterns of "2.5-lemma" or something between a trilemma and a dilemma: without capital controls, a flexible exchange rate regime offers some monetary policy autonomy when the center country tightens its monetary policy, yet it fails to do so when the center country lowers its interest rate. Capital controls help to insulate periphery countries from monetary policy shocks from the center country even when the latter lowers its interest rate.
\end{abstract}

Xuehui Han

Asian Development Bank

6 ADB Avenue

Mandaluyong City

Manila, Philippines 1550

xuehuihan@adb.org

Shang-Jin Wei

Graduate School of Business

Columbia University

Uris Hall 619

3022 Broadway

New York, NY 10027-6902

and NBER

shangjin.wei@columbia.edu 


\section{Introduction}

In an inter-connected world, foreign monetary shocks are often a key risk for emerging market economies and other developing countries. This paper re-examines the roles of the nominal exchange rate regime and capital flow management in a country's resilience to foreign monetary shocks. There is no shortage of recent reminders of foreign monetary shocks. When the US Federal Reserve raised the interest rate multiple times in the early 2000s, when it rolled out quantitative easing (QE) after the onset of the Global Financial Crisis (GFC), when it talked about "tapering" in May 2013, when the increase in the US interest rate actually took place in December 2015, when the market revised downward expectations in March 2016 about the number of US interest rate increases that might happen in 2016, and when the Fed further postponed another rate increase in June and August of 2016, we saw each time that international capital flows to emerging markets reacted and interest rates in many developing countries also appeared to have reacted often (but not always) to follow the actual or anticipated changes in US interest rates.

What does it take for a country to have some buffer against foreign monetary shocks? The literature is somewhat split on this topic. The textbook notion that a flexible exchange rate regime provides insulation against foreign shocks is said to be supported by the data in Edwards (2012), Klein and Shambaugh (2015), and Obstfeld (2015), among others. On the other hand, using equity prices for firms across emerging market economies, Tong and Wei (2011) find that, in terms of the extent to which an emerging market economy was affected by the GFC, a flexible nominal exchange rate by itself does not provide much help but capital flow management encouraging more FDI and less non-FDI type of capital flows before the GFC tends to provide some cushion during the GFC. In terms of pair-wise correlations among cross-border capital flows, Rey (2015) points out that whether a country has a flexible or a fixed nominal exchange rate regime does not seem to make a difference, but whether it has capital controls does. The findings of the last two papers are consistent with each other. Rey's (2015) title, "dilemma not trilemma," succinctly highlights a view that capital controls appear necessary (whereas a flexible exchange rate regime is not) for a country to be insulated from global financial cycles. Interestingly, neither Tong and Wei (2011) nor Rey (2015) directly examine how combinations of nominal exchange rate regimes 
and capital controls affect a country's conduct of monetary policy in relation to foreign monetary shocks.

In this paper, we investigate the effectiveness of different combinations of exchange rate regimes and capital control measures, and we pay special attention to accounting for possible correlations in monetary policies due to common shocks. We will report evidence of "2.5-lemma" or something between a trilemma and a dilemma: a flexible exchange rate regime appears to convey monetary policy autonomy to peripheral countries when the center country raises its interest rate, but does not do so when the center lowers its interest rate. In other words, "fear of floating" mostly takes the form of "fear of appreciation." Capital controls provide insulation to peripheral countries from foreign monetary policy shocks even when the center lowers its interest rate. The "2.5-lemma" pattern is more nuanced than the findings in the existing literature.

The paper makes a number of methodological innovations. First, we use an estimated surprise component of the inflation forecast and an estimated surprise component of the growth forecast together with the Taylor rule specification to capture the desired change in a peripheral country's monetary policy based on a country's own domestic needs. The Taylor specification includes the stability of real exchange rates as a goal of domestic monetary policy, in addition to output and price stabilization, as suggested by Engle (2011). Such a framework allows us to control for possible coincidental co-movement of a country's monetary policy with that of the United States (US). In other words, sometimes the domestic needs of two different central banks may coincide such that their chosen monetary policies are similar even when there is no policy spillover. Hence, not all co-movements of interest rates in the peripheral and center countries would be interpreted as transmission of monetary policies or lack of monetary policy autonomy.

Second, the paper provides a specification and an estimation method that can include the QE episodes, when we do not observe much change in the US interest rate. We use a likelihood function to incorporate the latent (but censored) changes in the US policy rate. When the US interest rate is above the lower bound, changes in US monetary policy stance can be directly observed from the changes in its interest rate. When the US interest rate is at or near the lower bound, on the other hand, changes in the US policy stance are inferred from changes in the US money supply relative to its aggregate output. Instead of using a 
pre-estimated "shadow rate" for the zero-lower-bound period, as done by Wu and Xia (2016) and Krippner (2014), we estimate the parameters jointly with the equation on international transmission of monetary shocks ${ }^{3}$. To our best knowledge, this is among the first attempts in the literature to incorporate the lower-bound episodes in a study of international monetary policy transmissions.

There are important precursors to this paper in the literature. Obstfeld (2015) examines the role of the nominal exchange rate regime but does not explicitly examine the role of capital controls in the international transmission of monetary policy shocks. Since many countries with a flexible nominal exchange rate regime also maintain capital flow management, what appears to be the effect of a flexible exchange rate could instead be the effect of capital controls. Han and Wei (2014) and Klein and Shambaugh (2015) look at both but do not fully account for common shocks that can give the appearance of lack of policy independence of the peripheral country. They also reach opposite conclusions. While Han and Wei (2014) find that a flexible exchange rate by itself does not confer monetary policy autonomy, Klein and Shambaugh (2015) find that a moderately flexible exchange rate does but partial capital controls do not. Aizenman et al. (2016) introduced both exchange rate stability and financial openness in analyzing the sensitivity of peripheral countries' policy rates to core countries' monetary policies. They found that economies that pursue greater exchange rate stability and financial openness face stronger links with center economies, which is consistent with our conclusion. However, they introduced exchange rate stability and financial openness separately and not as a policy combination. In our specification, a policy regime is jointly determined by a combination of capital controls and a nominal exchange rate regime.

The paper also differs from the previous papers by explicitly allowing for asymmetric responses by peripheral countries on a flexible exchange rate regime to central country interest rate changes. That is, peripheral countries may or may not feel equally compelled to follow the center country's policy moves depending on whether the center loosens or tightens its monetary policy. In addition, this paper is the first to use estimated surprise components in GDP growth and inflation forecasts in gauging domestic policy need and the

\footnotetext{
${ }^{3}$ Aizenman et al. (2016) analyzed the US quantitative easing episode using the $\mathrm{Wu}$ and Xia (2016) shadow rate directly instead of estimating the shadow rates and other parameters jointly.
} 
first in incorporating the quantitative easing episode in the context of international monetary policy transmission.

Farhi and Werning (2014) use a New Keynesian model to study whether capital controls are needed for welfare maximization when a country already has a flexible exchange rate. They found that the answer is yes: even with a flexible exchange rate regime, capital controls raise welfare. In their framework, capital controls are introduced as "taxes" over capital inflows during capital inflow surges caused by negative risk premium shocks and as "subsidies" to capital outflows when the capital flows revert. That is, capital controls work in an opposite way of risk premium shocks. When social welfare is affected by both terms of trade and the intertemporal path of consumption, it is generally useful to employ both tools. With a flexible exchange rate to influence terms of trade and capital controls to influence intertemporal consumption, social welfare is higher than just using one of the tools. This theoretical result is consistent with the "2.5-lemma" pattern we will report. That is, when the center country loosens its monetary policy (which tends to generate a capital flow surge into other countries), peripheral countries appear to feel compelled to follow suit by lowering their interest rates, unless they have capital control measures in place.

This paper is organized as follows: Section 2 sets up the modeling specification and introduces the data; Section 3 presents the empirical estimation results; Section 4 extends the analysis by proposing a method to include more recent episodes in which US interest rates may reach the zero lower bound; Section 5 reports additional robustness checks; finally, Section 6 concludes.

\section{Specification and Data}

\subsection{Empirical model}

Our baseline specification is built on two steps. The first step describes the relationship between the monetary policy of a periphery country and that of a center country, which we assume is the United States, conditional on other determinants of the periphery's monetary policy. Let $\Delta i_{i, t}^{p}$, denote the changes in policy interest rate of (peripheral) country $i$ in time $t$. We assume it depends on four factors: the value of the policy rate one period ago, $i_{i, t-1}^{p}$; a change in the desired policy rate, $\Delta r_{i, t}^{P *}$, driven solely by domestic factors; a change in the 
interest rate driven by the center country, $\Delta r_{t}^{U S}$; and a global financial cycle factor, which we approximate by the percentage changes of the Chicago Board Options Exchange Market Volatility Index, $\Delta V I X_{t}$. More precisely,

(1) $\Delta i_{i, t}^{p}=\lambda i_{i, t-1}^{p}+\gamma_{1} \Delta r_{i, t}^{P *}+\gamma_{2} \Delta r_{t}^{U S}+\delta \Delta V I X_{t}+\varepsilon_{i, t}$.

The lagged policy rate, $i_{i, t-1}^{p}$, could capture policy momentum or a notion of policy space. For example, a higher lagged policy rate allows more space for downward policy changes. We expect to have a negative estimate of the coefficient, $\lambda$.

When country 1 s interest rate is observed to have changed alongside with that of the United States, is it lack of monetary policy independence or coincidence of a common shock? To separate the two, we have to specify the desired change in country is policy rate that is driven solely by its domestic need, $\Delta r_{i, t}^{P *}$. We do this by a combination of the Taylor rule and the estimated surprise components in growth and inflation forecasts. In other words, $\Delta r_{i, t}^{P *}$ is assumed to be driven by news about the domestic output gap and the inflation gap.

However, different from Obstfeld (2015) and Han and Wei (2014), we use the revisions in semi-annual forecasts of GDP and CPI by the IMF's World Economic Outlook (WEO) to represent the surprise components in the output gap and the inflation gap. Economic theory tells us to expect positive coefficients on both factors.

Since domestic factors are not our focus in this study, in our baseline analysis, we do not differentiate the weights on the output surprise and the inflation surprise across countries. Let $r_{i, t}^{p *}$ be the desired monetary policy rate of country $i$; then $\Delta r_{i, t}^{P *}$ is the desired change in the policy rate since the previous period. The least squares regression model of the Taylor rule is defined as:

(2) $\Delta r_{i, t}^{P *}=\tilde{\mathrm{c}}+\widetilde{\phi_{1}} * \Delta G D P$ growth $_{i, t}+\widetilde{\phi_{2}} * \Delta$ Inflation $_{i, t}+\widetilde{e_{l, t}}$,

where $\tilde{c}$ is the intercept term and $\widetilde{e_{l, t}}$ is the error term. Crucially, $\Delta G D P$ growth $_{i, t}$ and $\Delta$ Inflation $_{i, t}$ are revisions to the projections of GDP growth and inflation rates by the IMF between its two projection horizons. The IMF releases its projections (typically) twice a year, in early April and September (sometimes October), respectively. For each country, the projections are done by desk economists in the Fund, with the overall coordination by its 
Research Department to ensure global consistency. The projections presumably take into account all available information to the Fund and the best judgments of the relevant Fund staff at the time of making the projections. Our maintained assumption is that the IMF projections of a member country's growth and inflation are unbiased estimates of the member central bank's projections. Due to IMF's privileged access to member countries' central banks and information and the caliber of its staff, such an assumption seems reasonable. It is also useful to note that IMF projections of growth and inflation are formally made conditional on the government's existing macroeconomic policies. That's why the projections are called projections rather than forecasts. ${ }^{4}$ One (helpful) consequence of the IMF methodology is that we do not need to worry about potentially endogenous responses of inflation and growth to anticipated changes in the interest rate.

In addition to inflation and output gaps, Engel (2011) included exchange rate misalignment into the loss function of policy makers and showed that exchange rate misalignments affect welfare. In our framework, instead of introducing the exchange rate arrangement into the Taylor rule, we allow the exchange rate to interact with capital controls and then to differentiate the spillover from the monetary policy of the core country (the United States). In other words, the role the exchange rate regime plays depends on the capital control and exchange rate arrangements.

Since our purpose is to find out which combinations of capital control regimes and nominal exchange rate systems can provide monetary policy independence, we make $\gamma_{2}$ in equation (1) a function of different regimes:

(3) $\gamma_{2}=\beta_{1} D_{\text {fixed.NC }}+\beta_{2} D_{\text {fixed.C }}+\beta_{3} D_{\text {flex.NC }}+\beta_{4} D_{\text {flex.C }}$

Where $D_{\text {fixed.NC }}=1$ if an economy chooses a fixed exchange rate regime without capital controls, and zero otherwise; $D_{\text {fixed.C }}=1$ if an economy chooses a fixed exchange rate regime plus capital controls, and zero otherwise; $D_{\text {flex.NC }}=1$ if an economy chooses a flexible exchange rate regime and no capital controls, and zero otherwise; finally, $D_{\text {flex.C }}=1$ if an economy chooses a flexible exchange rate regime plus capital controls, and zero otherwise.

4 See the Assumptions and Conventions (page ix) of World Economic Outlook October 2015 at https://www.imf.org/external/pubs/ft/weo/2015/02/pdf/text.pdf. The assumptions for the projections are described as "that established policies of national authorities will be maintained." 
With this specification, ${ }^{5}$ we can compare different $\beta$ coefficients directly and easily.

According to Obstfeld (2015), Rey (2015), and Bruno and Shin (2015), global financial cycles may affect a country's monetary policy stance separate from transmissions of monetary policies from the center to periphery countries. Following these authors, we introduce $\Delta V I X_{t}$ - the implied volatility of S\&P 500 index options, which is a common measure of global financial uncertainty-into our model. Lower values of $\Delta V I X_{t}$ are often interpreted as higher global risk appetite or greater tolerance of risk-taking.

Replacing $\Delta r_{i, t}^{P *}$ and $\gamma_{2}$ in equation (1) with equations (2) and (3), we have

(4) $\Delta i_{i, t}^{p}=c+\lambda i_{i, t-1}^{p}+\phi_{1} * \Delta G D P$ growth $_{i, t}+\phi_{2} * \Delta$ Inflation $_{i, t}$

$$
+\beta_{1} D_{\text {fixed.NC }} \Delta r_{i, t}^{U S}+\beta_{2} D_{\text {fixed. } .} \Delta r_{i, t}^{U S}+\beta_{3} D_{\text {flex.NC }} \Delta r_{i, t}^{U S}+\beta_{4} D_{\text {flex. }} \Delta r_{i, t}^{U S}+\delta \Delta V I X_{t}+e_{i, t},
$$

where $c$ is the intercept term and $e_{i, t}$ is an error term.

We are going to use equation (4) to test our hypothesis. As listed in Table 1, the baseline combination is the fixed exchange rate regime without capital controls. We interpret coefficient $\beta_{1}$ as a measure of spillover from a change in the US policy rate to the interest rate in an economy with a combination of a fixed exchange rate regime and no capital controls. If one wishes to interpret the trilemma hypothesis narrowly, one would expect $\beta_{1}=1$ or at least $\beta_{1}>0$. That is, there is no monetary policy autonomy for any economy with a fixed nominal exchange rate system and no capital controls. Common interpretations of the trilemma hypothesis often go beyond this. In particular, one expects that a flexible exchange rate system would confer monetary autonomy: $\beta_{3}=\beta_{4}=0$.

If capital controls are not effective because they are "leaky," we would observe $\beta_{2}>0$. On the other hand, if capital controls are completely effective in conferring monetary policy autonomy, we would expect $\beta_{2}=\beta_{4}=0$. On the other hand, if capital controls are partially effectively (but a flexible exchange rate system is not effective on its own), we may observe that $\beta_{1}>\beta_{2}>0$, and $\beta_{3}>\beta_{4}>0$. In other words, by checking for the signs and relative magnitudes of different $\beta \mathrm{s}$, we can find out whether a given policy regime (a combination of

\footnotetext{
5 Table 2 presents country/year classifications based on the four combinations.
} 
nominal exchange rate regime and capital control regime) provides no, partial, or complete monetary policy autonomy.

Obstfeld (2015) argued that in open economies, flexible exchange rates help in obtaining monetary policy autonomy at the short-end of the term structure, which, in our framework, is to test the hypotheses that $\beta_{1}>0$ and $\beta_{3}=0$.

We extend the baseline specification to incorporate the stability of real exchange rate as an additional goal in the desired policy rate (following Engel, 2011). The extended model is as follows:

(5) $\Delta r_{i, t}^{P *}=\tilde{\mathrm{c}}+\widetilde{\phi_{1}} * \Delta G D P$ growt $_{i, t}+\widetilde{\phi_{2}} * \Delta$ Inflation $_{i, t}+\widetilde{\phi_{3}} * \Delta$ Real exchange rate ex $_{i, t}+\widetilde{e_{l, t}}$,

(6) $\gamma_{2}=\beta_{1} D_{\text {fixed.NC }}+\beta_{2} D_{\text {fixed.C }}+\beta_{3, \text { pos }} D_{\text {flex.NC,USpos }}+\beta_{3, \text { neg }} D_{\text {flex.NC,USneg }}+\beta_{4, p o s} D_{\text {flex.C,USpos }}+$ $\beta_{4, \text { neg }} D_{\text {flex.C,USneg }}$,

where

$D_{\text {flex.NC,USpos }}=1$ for a flexible exchange rate regime, no capital controls, with positive US rate changes, and zero otherwise; $D_{\text {flex.NC,USneg }}=1$ for a flexible exchange rate regime, no capital controls, with negative US rate changes, and zero otherwise;

$D_{\text {flex.C,USpos }}=1$ for a flexible exchange rate regime, with capital controls, positive US rate changes, and zero otherwise; and $D_{\text {flex.C,USneg }}=1$ for a flexible exchange rate regime, with capital controls, negative US rate changes, and zero otherwise;

Real exchange rate is nominal exchange rate (in units of local currency per US dollar) adjusted by the differential in inflation rates between the country in question and the United States. Therefore, an increase in the value of real exchange rate means depreciation of local currency; if the country wishes to reduce RER instability, we expect $\phi_{3}>0$.

In equation (6), we allow economies with flexible exchange rate regime to respond differently to an increase or decrease in the US rate. If $\beta_{3}=0$ and $\beta_{4}>0$, it would imply that the countries are reluctant to follow tightening monetary policy by the United States but generally would follow a reduction in the interest rate by the United States. This would be interpreted as evidence of "fear of appreciation." For countries with capital controls (and 
still a flexible exchange rate), if there is no spillover in monetary policies regardless of a rise or fall of the US interest rate, we expect $\beta_{4, p o s}=\beta_{4, n e g}=0$.

\subsection{Data}

We include all economies with relevant data in our sample (60 countries in total), of which 24 are developing or emerging market countries. They are listed in Appendix Table A1. In our baseline analysis, we include Germany to represent euro currency countries and exclude all other euro currency countries since they have the same monetary policy as Germany. We further exclude countries pegged with the euro (post-1999) or pegged with the German mark (pre-1999). The resulting dataset includes 28 countries $^{6}$ (excluding the US) and 827 observations. As a robustness check, we did bring euro zone economies back in Section 5 to make our results comparable to the existing literature (such as Obstfeld, 2015).

From IMF's IFS dataset, we collected short-term interest rates - monthly policy rate data covering M1 1990 to M6 2014. If the monthly policy rate is not available, we use the discount rate. A detailed description can be found in Appendix Table A2. The policy rates are used to construct changes in policy rate, $\Delta i_{i, t}^{p}$. Based on equation (4) we also examine the long-term interest rates' response to US long-term interest rate changes. For this purpose, we use 10-year government bond yields. Among the 28 countries included in the short-term policy rate analysis, Argentina, Belarus, and Ecuador do not have appropriate long-term government bond yields data and therefore are not included in the long-term rate analysis. In Table A2, we list the details of the data sources and period coverage of government bond yields.

To incorporate the effects of domestic factors, as shown in equation (4), we need two variables - changes in GDP growth and changes in inflation. To get more "exogenous" changes in GDP growth and changes in inflation, instead of using the first-order difference of GDP growth and inflation, we use the IMF's WEO forecasts and the revisions in their forecasts of GDP growth and inflation. WEO's forecast data starts from 1990. Each year, WEO has two publications: one in April and the other in September (for some years, the

\footnotetext{
6 Argentina; Australia; Belarus; Bolivia; Brazil; Canada; Chile; China, People's Rep. of; Colombia; Costa Rica; Ecuador; Germany; Hong Kong, China; India; Indonesia; Israel; Japan; Korea, Republic of; Mexico; New Zealand; Pakistan; Peru; Philippines; Singapore; South Africa; Thailand; Turkey; United Kingdom.
} 
second issue was released in October). For the forecast of each year, we use two revisions. For example, for the forecast of GDP (output) growth for year 2000, we use the forecasts published in WEO in October 1999, April 2000, and September 2000 to calculate two changes (revisions). ${ }^{7}$ The same rules apply to the changes in inflation calculations. The lefthand side policy rate changes $\Delta i_{i, t}^{p}$ and the changes in US policy rate are calculated as the difference of monthly policy rates between the two adjacent WEO publication months.

We use the IMF de facto exchange rate regime classification by Ilzetzki et al. (2011) to define fixed and flexible exchange rate regimes. Classification $1^{8}$ is defined as fixed exchange rate. The remaining categories $2-6^{9}$ are defined as flexible exchange rate. Countries that were pegged with the German mark or euro were re-defined as flexible exchange rate since we solely focus on US monetary policy shocks in this analysis. The detailed descriptions drawn from Ilzetzki et al. (2011) can be found in Table A3 in the Appendix. ${ }^{10}$ An alternative regime classification by the IMF's Annual Report on Exchange Arrangements and Exchange Restrictions (AREAER) is used in the robustness check analysis. It starts from 1999. We label countries in categories 1-3 (pre-2008) and 1-4 (post2008) as the ones with a fixed exchange rate regime. Detailed descriptions can be found in Table A4 in the Appendix.

While the People's Republic of China (PRC) was classified under a flexible exchange rate regime (category 3) from 2002 to 2009 in the IMF de facto regime classification, (as shown in Table 2), it is classified as fixed during 2002-2005 and flexible during 2006-2007 by AREAER. We will use the alternative classification as a robustness check. As it turns out, our main inferences are not affected by this change in classification. The index of

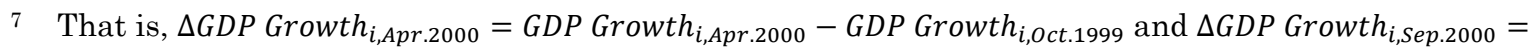
GDP growth gi,Sep.2000 $_{\text {GDP }}$ growth $_{i, A p r .2000}$.

8 Including: no separate legal tender, pre-announced peg or currency board arrangement, pre-announced horizontal band that is narrower than or equal to $+/-2 \%$, and de facto peg.

9 Category 2 includes pre-announced crawling pegs, pre-announced crawling bands that are narrower than or equal to $+/-2 \%$, de facto crawling pegs, and de facto crawling bands that are narrower than or equal to $+/-2 \%$; category 3 includes pre-announced crawling bands that are wider than or equal to $+/-2 \%$, de facto crawling bands that are narrower than or equal to $+/-5 \%$, moving bands that are narrower than or equal to $+/-2 \%$ (i.e., that which allow for both appreciation and depreciation over time), and managed floating; category 4 includes freely floating; category 5 is "freely falling" (typically with hyperinflation); and category 6 is dual market in which parallel market data is missing.

10 We further revise the classification for Hong Kong, China. In the Ilzetzki et al. (2011) classification, from 1974 to 1997, it was defined as category 3. However, the Hong Kong dollar has been pegged to the US dollar since 1983. Therefore, in our dataset, we classify it as fixed exchange rate regime. 
capital controls is defined as 1-Chinn and Ito's (2008) financial openness index. In the baseline estimation, we focus on two discrete cases: no capital controls, and with at least some capital controls.

The nominal exchange rates and the money supply variables (M1 and M2) are from IMF's International Financial Statistics. The aggregated real GDP of the US from CEIC (Bureau of Economic Analysis) is used to calculate implied interest rate for the zero-bound periods.

Since the policy rate in the US reached zero bound since September 2009, our baseline analysis is from May 1990 to April 2009. In Section 4, we will introduce a method to cover the period when the US interest rate is nearly zero.

\section{Analysis}

We start our analysis with the short-term policy rate as the focus. Before running the regression, we first examine the effectiveness of capital controls and exchange rate regimes by checking the associations of domestic policy rate changes and US policy rate changes. We classify all countries within a $2 \times 2$ matrix, depending on whether they have a flexible or a fixed exchange rate regime, and whether they have capital controls or not. We illustrate the relationship between the degree of monetary policy dependence and the features of the "regime" by a scatter plot (Figure 1): changes in domestic policy rate (vertical axis) are plotted against changes in US policy rate (horizontal axis). To reduce noise, we first grouped observations in each regime into twenty groups evenly and took the group average. Therefore, for each regime, we have twenty observations. Based on these constructed observations, a linear regression line was fitted, as shown by the solid red line; the $90 \%$ confidence interval is represented by the dashed red lines. The fitted regression lines for regimes without capital control are significantly positive whereas those for regimes with capital controls are not.

To test the hypothesis systematically, we turn to a regression analysis based on equation (4) and report the baseline estimation in Table 3.

As presented in column 1 of Table 3, consistent with our expectation, the coefficient

estimate of $\lambda$ for the lagged policy rate $(-0.048)$ is negative and statistically significant at 
$10 \%$. This implies that there is a stabilizing tendency for policy rate adjustments. With a higher lagged policy rate per se, the policy maker tends to adjust the current policy lower.

The coefficient estimate for $\triangle G D P$ growt $_{i, t}$ is 0.096 , but with no statistically significant difference from zero. The coefficient estimate for $\Delta$ Inflation $_{i, t}$ is 0.329 , statistically significant at 10\%. These estimates are different from the classic Taylor rule parameters for output gap and inflation gap. ${ }^{11}$ However, selected recent empirical findings with various Taylor rule-derived formulas provide comparable estimates. For example, Boivin and Giannoni (2006) estimate a forward-looking Taylor rule with two lagged policy rates as additional explanatory variables to formulate US monetary policy. Their estimate for output gap is 0.000 for both the pre-1979 and post-1979 periods and their estimate for inflation gap is 0.276 for pre-1979 and 0.508 for post-1979. Comparable estimates were also found in Kawai and Liu (2015) for the PRC and Coibion and Gorodnichenko (2011) for selected years in the US. Engel (2011) argues that when there are currency misalignments, ${ }^{12}$ the optimal monetary policy trades off targeting misalignments with inflation and output goals, under which the resulting Taylor rule relates the nominal interest rate in each country only to the CPI inflation in that country, the efficient real interest rate, and markup shocks. The absence of output gap in this optimal monetary policy partially justifies the coefficient estimate of 0.096 for $\Delta G D P$ growth $_{i, t}$ in our results.

The coefficient for the benchmark regime, $\beta_{1}$, turns out to be positive and statistically significant at $10 \%$. That is, the interest rate of a peripheral country with a fixed exchange rate regime and without capital controls tends to increase by 65 basis points when there is a 100 basis point increase in the US interest rate.

The coefficients for regimes with capital controls, $\beta_{2}$ and $\beta_{4}$, are not statistically significantly different from zero. This is consistent with an interpretation that capital controls allow a country's monetary policy to be immune from changes in the US rate.

However, the coefficient for the regime with flexible exchange rate without capital controls, $\beta_{3}$, is positive and statistically significant at $10 \%$ too, with an increase in interest

\footnotetext{
11 As a robustness check in a later section, we pre-assign a coefficient of 0.5 for both the output gap and inflation gap.

12 Households in the home and foreign countries pay different prices for the identical good.
} 
rate of 45 basis points following a 100 basis point increase in the US interest rate. This casts some doubt on the notion that a flexible exchange rate can provide monetary policy independence. Instead, our findings suggest that countries adopting a flexible exchange rate but without capital controls do not have policy insulation, and tend to follow changes in US monetary policy $\left(\beta_{3}=0.45\right)$. Because $\beta_{3}=0.45<\beta_{1}=0.65$, one could say that the dependence of monetary policy on the US in this regime is somewhat milder than if the country also has a fixed exchange rate regime but still without capital controls.

In other words, a mere flexible exchange rate regime does not confer monetary policy autonomy. Some forms of capital control appear to provide some buffer. Judging from the point estimates, a combination of capital controls and a flexible exchange rate regime yields the estimates closest to zero across all specifications and may provide the most autonomy.

Since year 1999 is the starting year of the euro zone (also the middle point of our sample), we examine whether the start of the euro zone has changed the power of our model by splitting the sample into two subsamples: 1990-1998 and 1999-2009. As shown in columns (2) and (3) of Table 3, none of the coefficients for the period 1990-1998 are significant. The adjusted R-squared is 0.000 . On the contrary, the coefficients for the period 1999-2009 (column 3) show similarity with that of the whole sample (column 1). The adjusted $\mathrm{R}$-squared is 0.30 . The difference between the periods 1990-1998 and 1999-2009 implies that the resilience of monetary policy to international monetary policy shocks gets weaker from 1990-1998 to 1999-2009 (significant positive coefficient estimates for the regimes of fixed exchange rate without capital controls and flexible exchange rate without capital controls), which is consistent with the common observation of higher integration of global capital markets (see, for example, Rey (2015)). The extensions and robustness check in the following analysis are thus based on the period 1999-2009. In column (4), we present the estimation results after excluding one outlier (Argentina in April 2001). ${ }^{13}$ The results still hold except for the coefficient estimate for $\beta_{2}$ at -0.05 . All the remaining estimations for short-term policy rate are going to be based on the dataset used in column (4). Meanwhile, Hellerstein (2011) and Dahlquist and Hasseltoft (2013) argued that the long-

\footnotetext{
${ }^{13}$ Note that the coefficient estimate for $\beta_{2}$ is -0.249 (although not significant). For all country-periods with a fixed exchange rate and capital controls, when we plot peripheral countries' interest rate changes against US interest rate changes, Argentina in April 2001 is a visible outlier that drives the negative estimate. We exclude this data point in the remaining estimations.
} 
term interest rate is more correlated across countries than the short-term rate because of integrated bond markets across countries, in which countries' term premiums are closely linked to the US bond premium. Obstfeld (2015) therefore compared the short-term interest rate with the long-term interest rate in evaluating monetary policy independence and found that in open economies, the flexible exchange rate allows countries to exercise considerable monetary autonomy at the short-term structure, but does not have much power at the longterm structure.

We re-visited the conclusion with our modeling specification by replacing policy rates with 10-year government bond yields. As shown in Table A2 in the Appendix, 10-year government bond yield data are more limited than those of the policy rate. For long-term bond yields, we exclude three countries - Argentina, Belarus, and Ecuador - because these countries did not have appropriate long-term government bond yield data; and exclude certain episodes since some countries, such as the PRC and Brazil, only have shorter coverage. The empirical estimation results with long-term government bond yields as the dependent variable are presented in column (5) in Table 3. Our general conclusion for the short-term interest rate analysis holds for long-term interest rates. The one period lagged long-term interest rate $i_{i, t-1}^{L}$ has a significant negative sign. The revisions in GDP and CPI forecasts have significant positive signs, but with a much lower coefficient for CPI revision (compared with the baseline case for short-term interest rate as in column (4) of Table 3), which implies that the role of long-term interest rates in domestic macroeconomic targeting is much smaller than that of the short-term policy rate. Our findings also echo the argument of Obstfeld (2015): the domestic macro variables play roles in determining longterm interest rates.

As shown in column (5) in Table 3, the coefficients of the exchange rate and capital control regimes for the long-term interest rate analysis are similar to those under the shortterm interest rate analysis. Coefficients for both regimes without capital controls are significantly positive with a higher estimate for the regime with fixed exchange rate at 0.68 and a lower estimate for the regime with flexible exchange rate at 0.41 . Therefore, our conclusion that capital controls are more effective in helping economies to be less affected by US monetary policy shocks and countries with flexible exchange rates without capital 
controls tend to adjust their policy rates in tandem with the US rate holds for both shortend and long-end of the term structures.

To verify that our findings are not subject to bias induced by a smaller sample for the long-term bond yield data, we intentionally reduced data set of the short-term policy rates by focusing on the same country-episodes as in the data for the long-term rates. The results are shown in column (2) in Table A5 in the appendix and do not change from the baseline case.

By introducing capital control differentiation explicitly in the model, our findings partially support and partially refute those of Obstfeld (2015). We found that at the shortend of the term structure, in open economies (regimes without capital controls in our framework), while the flexible exchange rate allows higher autonomy compared with the fixed exchange rate, it does not provide total immunity. Our conjecture is that open economies with flexible exchange rates willingly go in tandem with US monetary policy changes.

We carried out F-tests for the null hypotheses $\beta_{2}=\beta_{4}$ and $\beta_{4}=\beta_{3}$. As shown by the Ftest results in Table 3 , for columns (1), (2), and (5), $\beta_{2}$ is not significantly different from $\beta_{4}$. This means that interest rate responses are not different between fixed or flexible exchange rates if there are capital controls. On the other hand, from columns (1), (3), and (4), $\beta_{4}$ is significantly different from $\beta_{3}$. This means that flexible regimes with capital controls are different from flexible regimes without capital controls when it comes to monetary policy transmission.

Table 4 presents the estimation results for an extended model that allows for asymmetric responses under a flexible exchange rate regime and incorporates real exchange rate stability in the Taylor rule as described by equations (5) and (6). The results are broadly similar to before. In particular, a flexible exchange rate regime appears to offer policy autonomy when the center country raises its interest rate, but not when it lowers the rate. A flexible exchange rate regime in combination with capital controls appears to offer monetary policy autonomy to peripheral countries. These results are summarized in Figure $1 b$. 


\section{The Lower-bound Episodes}

The QE approach of the US Federal Reserve creates complications for specification (4) above, as downward adjustments in the US interest rate are not observed even though the $\mathrm{QE}$ is clearly intended to further loosen the monetary policy stance. More importantly, it is conceptually possible that the transmission patterns of monetary policy change qualitatively under QE. In particular, if the US interest rate is stuck near zero, emerging market exchange rate responses to changes in the US monetary aggregates can be weaker than when the US interest rate is above zero. Does this happen in the data? Does the effectiveness of capital controls and the nominal exchange rate regime change from the normal to the QE world?

In order to answer these questions, we generalize specification (4) by replacing the observed US interest rate by a latent interest rate, whose value depends on whether the US interest rate reaches the lower bound. During the lower-bound episodes, agents are assumed to form their views on US monetary policy by using the US money supply (relative to aggregate output) instead. The model includes three equations as follows:

(7) $\Delta i_{i, t}^{p}=\lambda i_{i, t-1}^{p}+\gamma_{1} \Delta r_{i, t}^{P *}+\gamma_{2} \Delta r_{t}^{U S \#}+\delta \Delta V I X_{t}+\varepsilon_{i, t}$,

(8) $\Delta r_{t}^{U S \#}=\left\{\begin{array}{cl}\Delta r_{t}^{U S}, & r_{t}^{U S *}>\text { Lower Bound } \\ \Delta r_{t}^{U S *}, & r_{t}^{U S *}=\text { Lower Bound }\end{array}\right.$,

(9) $r_{t}^{U S *}=\theta_{1}+\theta_{2} \log M_{t}+\theta_{3} \log Y_{t}+\epsilon_{t} \cdot{ }^{14}$

Equation (7) is similar as equation (1), where $\Delta r_{i, t}^{P *}$ is the desired change in the interest rate for the peripheral country based on a Taylor rule that takes into account the country's domestic need. The main difference is that the changes in the stance of US monetary policy, $\Delta r_{t}^{U S \#}$, is now defined by Equations (8) and (9). When the US interest rate is above its lower bound, agents would use the observed US policy rate changes to gauge changes in US monetary policy, $\Delta r_{t}^{U S \# ;}$ however, when the US policy rate reaches its lower bound, the changes in US monetary policy stance is inferred from movements in real money supply $M_{t}$ in relation to real aggregate output $Y_{t}$, as indicated in equation (9). Equation (9) resembles

14 The resulting first-order difference would take the form of $\Delta r_{t}^{U S *}=\theta_{2}\left(\log M_{t}-\log M_{t-1}\right)+$ $\theta_{3}\left(\log Y_{t}-\log Y_{t-1}\right)+\left(\epsilon_{t}-\epsilon_{t-1}\right)$. 
the standard money market equilibrium condition except that the interest rate in question is the latent interest rate. The terms $\varepsilon_{i, t}$ and $\epsilon_{t}$ are assumed to be i.i.d.

Note that when the US interest rate is above the lower bound, the observed policy rate is used to gauge US monetary policy stance because it is less noisy than what is inferred via equation (9).

We estimate the model by maximum likelihood. Based on equations (7) to (9), we construct the likelihood function as

$$
\begin{array}{r}
\mathrm{L}=\prod_{\mathrm{i}=1}^{\mathrm{N}}\left(\phi\left(\frac{\Delta i_{i, t}^{p}-\left(\lambda i_{i, t-1}^{p}+\gamma_{1} \Delta r_{i, t}^{P *}+\gamma_{2} \Delta r_{t}^{U S}+\delta \Delta V I X_{t}\right)}{\sigma_{\varepsilon}}\right)\left(1-\Phi\left(\frac{0-\left(\theta_{1}+\theta_{2} \log M_{t}+\theta_{3} \log Y_{t}\right)}{\sigma_{\epsilon}}\right)\right)\right)^{\mathrm{Y}_{\mathrm{i}}} \\
\left(\phi\left(\frac{\Delta i_{i, t}^{p}-\left(\lambda i_{i, t-1}^{p}+\gamma_{1} \Delta r_{i, t}^{P *}+\gamma_{2}\left(\theta_{2} \Delta \log M_{t}+\theta_{3} \Delta \log Y_{t}\right)+\delta \Delta V I X_{t}\right)}{\gamma_{2} \sigma_{\epsilon_{\mathrm{t}}-\epsilon_{\mathrm{t}-1}+\sigma_{\varepsilon}}}\right) \Phi\left(\frac{0-\left(\theta_{1}+\theta_{2} \log M_{t}+\theta_{3} \log Y_{t}\right)}{\sigma_{\epsilon}}\right)\right)^{1-\mathrm{Y}_{\mathrm{i}}},
\end{array}
$$

where $\mathrm{Y}_{\mathrm{i}}=1$, if $r_{t}^{\text {US* }}>$ Lower Bound; $\mathrm{Y}_{\mathrm{i}}=0$, otherwise.

That is, when $r_{t}^{U S *}>$ Lower Bound, the observation of policy rate $\Delta i_{i, t}^{p}$ is a joint event of an observable $\Delta r_{t}^{U S}$ (the density function of $\phi(\cdot)$ in the first half part of the likelihood function) and $r_{t}^{U S *}>$ Lower Bound (the right section above the lower bound in the distribution function as $1-\Phi(\cdot))$, which is included as the first half part of the likelihood function. When $r_{t}^{U S *}=$ Lower Bound, the policy rate $\Delta i_{i, t}^{p}$ is a joint event of approximated changes in the US policy rate as indicated by $\theta_{2} \Delta \log M_{t}+\theta_{3} \Delta \log Y_{t}$ (the density function of $\phi(\cdot)$ in the second half part of the likelihood function) and $r_{t}^{U S *}=$ Lower Bound (the right section below the lower bound in the distribution function as $\Phi(\cdot))$.

The sample is extended to $2012^{15}$ to include the period when the US policy rate practically reached the lower bound and the QE approach was employed. As straightforward extensions of the above specification, we also allow for exchange rate stability in the Taylor rule and asymmetric responses of the peripheral countries with a flexible exchange rate regime. That is, to replace $\Delta \mathrm{r}_{\mathrm{i}, \mathrm{t}}^{\mathrm{P} *}$ and $\gamma_{2}$ in the likelihood function (10) with the equation (5)

15 Note that the exchange rate regime classification (AREAER) ends in 2012. 
and (6). For lower-bound episodes, $\theta_{2}\left(\log \mathrm{M}_{\mathrm{t}}-\log \mathrm{M}_{\mathrm{t}-1}\right)+{ }_{3}\left(\log \mathrm{Y}_{\mathrm{t}}-\log \mathrm{Y}_{\mathrm{t}-1}\right)$ is used to make judgment on whether there is a positive $\Delta \mathrm{r}_{\mathrm{t}}^{\mathrm{US} *}$ or negative $\Delta \mathrm{r}_{\mathrm{t}}^{\mathrm{US} *}$.

We bootstrap the sample with replacement for 100 times and optimize the logarithm using a quasi-Newton algorithm for each bootstrapped sample. The standard error from the 100 estimates on bootstrapped samples is used to judge the significance level.

The results are reported in Table 5. Because the maximum likelihood estimation could be sensitive to the choice of initial values if some initial values lead to a local maximum that is different from the global maximum, we experiment with different sets of initial values. In Column 1, we use the OLS estimates (reported in Column 6) as the initial values. In Columns 2 and 3, we use the OLS estimates plus one or two times their standard errors, respectively, as the initial values. In Columns 4 and 5, we use the OLS estimates minus one or two times their standard errors, respectively, as the initial values.

Comparing across the five columns in Table 5, we find broad agreement in the individual coefficient estimates regardless of the choices of initial values. In particular, we see evidence in support of the "2.5-lemma" pattern. First, a fixed nominal exchange rate without capital control offers no monetary policy autonomy (as suggested by $\beta_{1}=0.50$ to 0.52). Second, a flexible exchange rate regime without capital controls confers no monetary autonomy when the United States loosens its monetary policy $\left(\beta_{3, n e g}=0.60\right.$ and significant), but it allows somewhat better policy insulation when the United States tightens its monetary policy stance $\left(\beta_{3, p o s}=0.18<0.60=\beta_{3, n e g}\right)$. Finally, capital controls confer monetary policy autonomy to peripheral countries regardless of their nominal exchange rate regimes (statistically, $\beta_{2}=\beta_{4, p o s}=\beta_{4, n e g}=0$ cannot be rejected and numerically these point estimates are also much closer to zero).

Note that the coefficient on $\Delta V I X_{t}$ is now statistically significant, which is different from the baseline estimates in Table 3. This might suggest that the notion of a global financial cycle works more strongly during the QE episodes (2009-2012). Note also that the coefficients on log money supply and log output have the right signs. For example, a negative sign on log money supply means that an increase in money supply implies a reduction in the latent interest rate. However, due to large standard errors, these point 
estimates are not statistically significant. Finally, Wu and Xia (2016 and Krippner (2014) provided their estimates of the shadow US interest rate during the US QE period. Because we jointly estimate the latent interest rate during the $\mathrm{QE}$ episode and the international monetary policy transmissions, our approach is more efficient than pursuing a two-step approach of estimating the shadow interest rate first and estimating the international transmissions second. Nonetheless, as a robustness check, we also feed the shadow US interest rate estimates from Wu and Xia (2016 into Equations (5)-(6) and obtain similar results as those reported in Table 5 .

\section{Extensions and Robustness Checks}

We conduct a series of robustness checks and extensions. In each exercise, we make one change to the specification as specified below while maintaining other features of the baseline case.

\section{$\underline{\text { Re-defining capital controls }}$}

Instead of defining capital controls as a dichotomous variable, we now define it continuously as 1-(Chinn-Ito index). In this case, a greater value means stricter capital controls. The results are reported in Columns 1 and 2 of Table 6 , for short-term and longterm interest rates, respectively.

The pattern of "2.5-lemma" can be seen from the results. First, there is no monetary policy autonomy by peripheral countries if they have a combination of a fixed exchange rate and no capital controls. This can be seen from the fact that $\beta_{1}=0.487$ and is statistically significant.

Second, for a country with a flexible exchange rate regime but without capital controls, it follows the US policy moves (i.e., no policy autonomy) when the latter loosens monetary policy (as can be seen by the coefficient on the triple interaction term among a dummy for a flexible exchange rate, a dummy for US loosening monetary policy, and the change in the US policy rate to be 0.369 and statistically significant). On the other hand, it appears to not follow US interest rate moves when the US raises its interest rate. 
Third, capital controls generally confer monetary policy autonomy to peripheral countries. For example, for countries on a fixed exchange rate regime, an increase in the value of the capital controls index from the $25^{\text {th }}$ percentile (or 0.31 ) to the $75^{\text {th }}$ percentile (or 0.84, approximately the value for the PRC during 1999-2001) would almost eliminate the impact from changes in the US interest rate (because $0.487-0.727 \times(0.84-0.31)=0.101)$ ). However, the coefficient on the interaction term between a fixed rate and the (continuously valued) capital control index is not statistically significant because the standard error is large.

Finally, different from Obstfeld (2015), we find no substantive difference between the result for the long-term interest rate (in Column 2) and that for the short-term interest rate (in Column 1).

\section{$\underline{\text { Re-classifying exchange rate regimes }}$}

As an alternative to the Reinhart and Rogoff classification, we use the exchange rate regime classifications in the IMF's AREAER. We label lack of a separate legal tender, currency board, and a conventional peg as a fixed exchange rate regime for short. All other categories are flexible exchange rate regimes. Since we focus on the influence of US monetary policy changes, the euro zone is represented by one country (Germany) and classified as a flexible exchange rate regime. More details can be found in Table A1 of the Appendix.

Regression results with the alternative classifications of nominal exchange rate regimes are reported in columns (3) and (4) of Table 6. We obtain essentially the same qualitative conclusions as in the baseline case presented in Table 4. In particular, the "2.5-lemma" patterns are confirmed in the data.

\section{Alternative specification of the Taylor rule}

Instead of estimating the coefficients on output and inflation gaps in the Taylor rule, we pre-assign 0.5 for the output gap and 1.5 for the inflation gap as suggested by Taylor (1993) and Hofmann and Bogdanova (2012). Transforming by first difference, we have

$$
\Delta r_{i, t}^{P *}=1.5 \Delta \pi+0.5 \Delta y,
$$


Rewriting the specification, we have

$$
\begin{aligned}
& \Delta i_{i, t}^{p}=\lambda i_{i, t-1}^{p}+\gamma_{1} \widetilde{\Delta r_{l, t}^{P *}}+\beta_{1} D_{\text {fixed.NC }} \Delta r_{i, t}^{U S}+\beta_{2} D_{\text {fixed.C }} \Delta r_{i, t}^{U S}+\beta_{3} D_{\text {flex.NC}} \Delta r_{i, t}^{U S} \\
& +\beta_{4} D_{\text {flex. } .} \Delta r_{i, t}^{U S}+\delta \Delta V I X_{t}+e_{i, t},
\end{aligned}
$$

where $\widetilde{\Delta r_{l, t}^{P *}}$ is calculated by taking the first difference of $r_{i, t}^{P *}$ based on equation (9).

For the short-term policy rate, the estimated value of $\gamma_{1}$ is 0.105 . To translate it into the

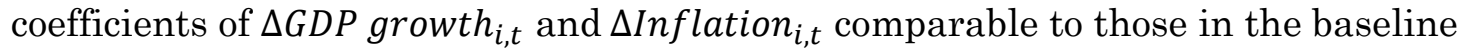
specification, we multiply the imposed coefficients with the estimated $\gamma_{1}$, as shown in columns (5) and (6) in Table $6 .{ }^{16}$ It turns out that the coefficient for $\Delta$ Inflation $_{i, t}$ is very close to the results in column (3) of Table 4 while the coefficient for $\Delta G D P$ growth $_{i, t}$ is more different. However, for the long-term interest rate, both the coefficients for $\Delta$ Inflation $_{i, t}$ (0.21) and $\triangle G D P$ growth $_{i, t}(0.07)$ are significant but smaller than the baseline estimations. With the pre-assigned Taylor rule, both the estimates for inflation gap and real exchange rate stability became insignificant and much smaller.

Most important for our purpose, we note that the main features of the " 2.5 -lemma" continue to hold. For example, under a flexible exchange rate regime, peripheral countries still follow the United States when the latter loosens its monetary policy (i.e., no autonomy) but the peripheral countries appear to be able to not follow the United States when the latter tightens monetary policy. In other words, there is fear of appreciation but not so much with depreciation. In addition, capital controls appear to offer peripheral countries monetary policy independence. Also, the difference between the short-term and long-term interest rates appears minor. So the "2.5-lemma" description also applies to long-term interest rates.

16 Using the imposed parameters of 0.5 for output gap and 1.5 for inflation gap, we approximate that the coefficient of $\triangle G D P$ growt $_{i, t}$ is $0.053\left(0.5^{*} 0.105\right)$ and $\Delta$ Inflation $_{i, t}$ is $0.158\left(1.5^{*} 0.105\right)$. 


\section{Seemingly unrelated regressions}

The error terms in the four different regimes might be correlated with each other even after controlling for the global financial cycle and the Taylor rules. In order to account for this possibility, we use seemingly unrelated regressions (SUR).

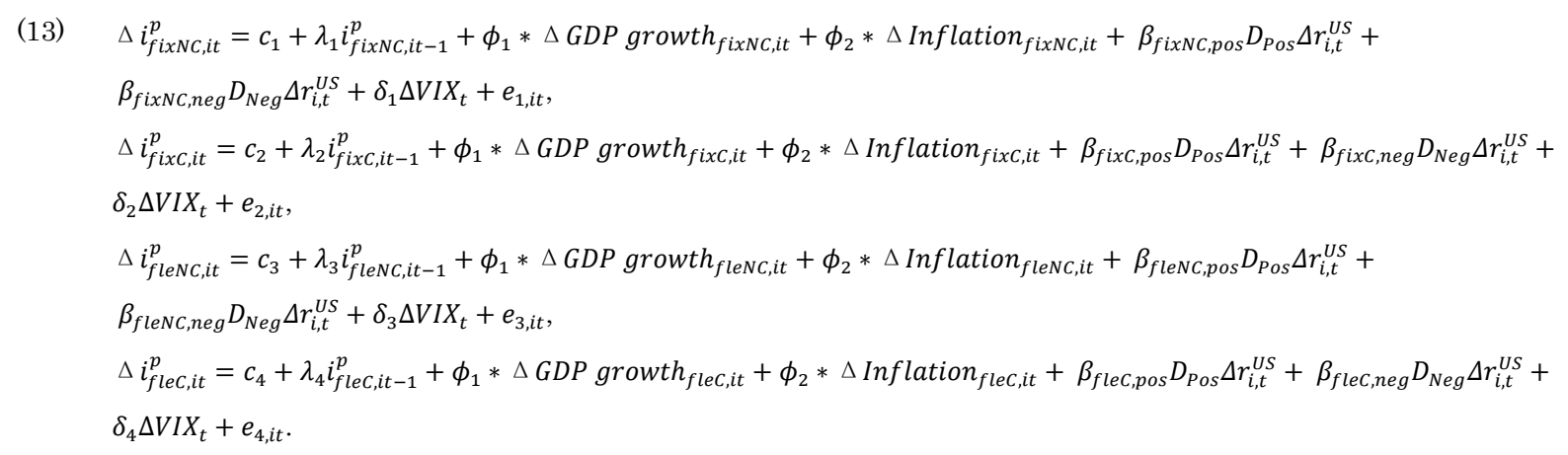

In a standard SUR specification, one usually has the same number of observations for each regime. We use a bootstrap approach to create a balanced sample (to obtain 307 observations in each regime, the same as the regime with the most observations). We repeat the sampling 500 times in Monte Carlo simulations to generate the means and the associated standard errors. We allow the $\lambda$ s and $\beta$ s to vary while keeping $\phi_{1}$ and $\phi_{2}$ constant across regimes.

The results are reported in Table 7. In this estimation, we allow for potentially different parameters in the four regimes (a regime is a combination of nominal exchange rate arrangement and capital control arrangement). Strikingly, we still get something between a trilemma and a dilemma: no monetary policy autonomy for peripheral countries with a fixed exchange rate and no capital controls; partial monetary policy autonomy for countries with a flexible exchange rate and no capital controls; and monetary policy autonomy for countries with capital controls.

\section{Another look at the global financial cycle effect}

One interesting result from our baseline estimation is that the variable representing the global financial cycle $-\Delta V I X_{t}$ is not statistically significant, in contrast to Rey (2015) and Obstfeld (2015). Because Obstfeld (2015) includes all individual euro area countries as separate observations whereas we group all euro countries into a single observation, the difference in the samples could be responsible for the difference in the result. To examine 
this possibility, we bring the euro zone economies back and re-run the regression. As column (1) in Table 8 shows, once we replicate the sample of Obstfeld (2015), $\Delta V I X_{t}$ becomes significantly positive in our specification too. In column (2), we exclude the episodes between 1990 and 1998 but still obtain similar results, This suggests that the "global financial cycle effects" are mostly driven by treating euro zone economies as separate observations. There is no robust support for a global financial cycle that is independent from changes in the center country monetary policy.

The coefficient estimate for the regime with a flexible exchange rate but no capital controls is 0.24 , which is much lower than 0.45 , the value of the same coefficient in the baseline case. This suggests that the euro zone economies collectively are more influenced by a common global financial cycle but less affected by US monetary policy changes.

It has also been argued that a valuation channel also allows a flexible exchange rate regime to augment monetary policy effectiveness (see Georgiadis and Mehl, 2015, and Meier, 2013). According to this hypothesis, when a country has positive net foreign currency assets, an appreciation of the domestic currency in response to a tightening in local monetary policy reduces the value of their net foreign currency assets in the local currency (and so too their total wealth). This leads to a contraction of domestic consumption and investment, augmenting monetary policy effectiveness. Meanwhile, they suggest that a global financial cycle can weaken the effectiveness of domestic monetary policy by allowing consumption smoothing through borrowing from abroad.

We would point out that the valuation channel is precisely one of the reasons why a flexible exchange rate regime without capital controls tends to follow the US when the US decreases its interest rate. When the US expands its monetary policy, if the periphery country does not follow suit, an appreciation of its currency could lead to a contraction of domestic investment and consumption. The periphery country, even if it has a flexible exchange rate, chooses to follow the US policy move precisely to nullify the valuation effect. While if the country has capital controls, the capital controls can effectively help avoid the "forced" appreciation of the local currency even if the periphery interest rate does not follow the US interest rate's movement. 
In our baseline framework, the global financial cycle effect is captured by $\Delta V I X_{t}$. Symmetrically, we add a net foreign asset variable - the share of foreign exchange reserves to GDP interacting with changes in the US rate. As shown in column (3) of Table 8, this interaction term has an insignificant estimate, in contrast to Georgiadis and Mehl (2015) and Meier (2013).

\section{Exchange rate responses to US interest rate changes}

Previous discussions suggest that, even for countries with a flexible exchange rate regime, presence or absence of capital controls makes a difference for the transmission of monetary policy shocks. Another way to investigate this possibility is to look at exchange rate responses to changes in the US interest rate. More precisely, we now look at the difference in the log exchange rate between two WEO reporting times (six months apart) as the dependent variable (where the exchange rate is defined as units of local currency per US dollar). The specification on the right hand side is similar to those in Table 3.

The results are reported in Table 9. The key coefficients of interest are the two associated with the policy regimes. For countries with a flexible exchange rate but no capital controls, the local currency tends to depreciate by about $2 \%$ following a US interest rate increase by one percentage point, according to Columns 1 or 3 . However, for countries with a flexible exchange rate but with capital controls, the extent of depreciation is much less at only $0.6 \%$, according to the same two columns. Thus, capital controls appear to blunt the exchange rate response even for countries with a flexible exchange rate system.

If we use a Talor rule with pre-assigned parameter values (similar to the last two columns of Table 6), then, following the US interest rate increase, the periphery country's currency would depreciate by about $1 \%$ if it does not have capital controls, and the exchange rate appears unresponsive to the US interest rate if the country has capital controls.

Note that the exchange rate response presumably has already taken into account the tendency for a periphery country's interest rate to respond to changes in the US interest rate. The fact that the observed exchange rate depreciation is bigger for countries without 
capital controls than for those with capital controls is consistent with the finding in earlier tables that the periphery country's interest rate response tends to be less than one for one.

\section{Conclusions}

In an increasingly inter-connected world, foreign monetary shocks are often a key risk for emerging market economies and other developing countries. This paper re-examines the roles of the nominal exchange rate regime and capital flow management in the transmission of international monetary shocks.

Relative to the existing literature, we introduce several methodological innovations/improvements. First, we introduce a measure of a country's desired change in the interest rate based on a Taylor rule and use the surprise components in inflation forecasts and growth forecasts by the IMF's World Economic Outlook to gauge the terms in the Taylor rule. We also incorporate exchange rate stability as a potential goal of monetary policy as suggested by Engel (2011). This modification allows us to effectively decompose comovements between a country's and the US interest rates into two parts, that which is caused by common shocks to fundamentals in the US and the peripheral country, and that which reflects the dependence of the peripheral country on US monetary policy, or "fear of deviations." Second, since quantitative easing has become a non-trivial part of the recent US monetary policy history, and little change in the US interest rate is observed during this period, we also develop a methodology that allows this part of the time series to be incorporated in the estimation. Third, we examine monetary autonomy both in terms of long-term and short-term interest rates.

The paper reaches different conclusions from some of the well-known papers in the literature. In particular, neither a dilemma nor a trilemma characterizes the patterns in the data completely. Instead, something in between seems to be the norm: for peripheral countries without capital controls, a flexible nominal exchange rate allows them to have some policy autonomy when the center country tightens its monetary policy. On the other hand, when the center country loosens its monetary policy, their "fear of appreciation" takes over and they often pursue similarly looser monetary policy even if the domestic Taylor rule suggests otherwise. In this sense, a flexible exchange rate offers asymmetric or incomplete insulation from foreign monetary policy shocks. In comparison, capital controls 
do offer insulation from foreign monetary policy shocks for peripheral countries on either a fixed or a flexible exchange rate regime.

Separately, we do not find robust support for the notion of a global financial cycle that is separate from the spillover of center country monetary policy shocks.

\section{References}

Aizenman, J., M. D. Chinn, and H. Ito. 2016. "Monetary Policy Spillovers and the Trilemma in the New Normal: Periphery Country Sensitivity to Core Country Conditions.” Journal of International Money and Finance 68: 298-330.

Boivin, J., and M. P. Giannoni. 2006. "Has Monetary Policy Become More Effective?” The Review of Economics and Statistics 88(3): 445-462.

Bruno, V., and H. S. Shin. 2015. "Capital flows and the risk-taking channel of monetary policy." Journal of Monetary Economics 71 (C): 119-132.

Calvo, G., and C. M. Reinhart. 2002. "Fear of Floating," Quarterly Journal of Economics 117 (2): 379-408.

Chinn, M. D., and H. Ito. 2008. "A New Measure of Financial Openness.” Journal of Comparative Policy Analysis 10(3): 309-322.

Coibion, O., and Y. Gorodnichenko. 2011. "Monetary Policy, Trend Inflation, and the Great Moderation: An Alternative Interpretation.” American Economic Review 101(1): $341-370$.

Dahlquist, M., and H. Hasseltoft. 2013. "International Bond Risk Premia.” Journal of International Economics 90(1): 17-32.

Di Giovanni, J., and J. Shambaugh. 2008. "The Impact of Foreign Interest Rates on the Economy: The Role of the Exchange Rate Regime." Journal of International Economics 74(2): 341-361. 
Edwards, S. 2012. "The Federal Reserve, the Emerging Markets, and Capital Controls: A High-Frequency Empirical Investigation.” Journal of Money, Credit and Banking 44(s2): 151-184.

Engel, C. 2011. "Currency Misalignment and Optimal Monetary Policy: A Reexamination." American Economic Review 101(6): 2796-2822.

Farhi, E., and I. Werning. 2014. "Dilemma not Trilemma? Capital Controls and Exchange Rates with Volatile Capital Flows.” IMF Economic Review 62(4): 569-605.

Georgiadis, G., and A. Mehl. 2015. "Trilemma, not Dilemma: Financial Globalization and Monetary Policy Effectiveness.” Working Paper No. 222. Globalization and Monetary Policy Institute. Federal Reserve Bank of Dallas.

Han, X., and S.-J. Wei. 2014. "Policy Choices and Resilience to International Monetary Shocks.” Global Economic Review 43(4): 319-337.

Hellerstein, R. 2011. "Global Bond Risk Premiums.” Staff Report No. 499. Federal Reserve Bank of New York.

Hofmann, B., and B. Bogdanova. 2012. "Taylor Rules and Monetary Policy: A Global 'Great Deviation'?" BIS Quarterly Review 37-49.

Ilzetzki, E., C. M. Reinhart, and K. S. Rogoff. 2011. "The Country Chronologies and Background Material to Exchange Rate Arrangements into the 21st Century: Will the Anchor Currency Hold?" Mimeo. Available at: http://personal.lse.ac.uk/ilzetzki/data/ERA-Country Chronologies 2011.pdf.

Kawai M., and L. Liu. 2015. "Trilemma Challenges for the People's Republic of China.” Asian Development Review 32(1): 49-89.

Klein, M., and J. Shambaugh. 2015. "Rounding the Corners of the Policy Trilemma: Sources of Monetary Policy Autonomy." American Economic Journal: Macroeconomics 7(4): $33-66$.

Krippner, L. 2014. "Measures of the Stance of United States Monetary Policy." Reserve Bank of New Zealand. Available at: http://www.rbnz.govt.nz/research-and- 
publications/research-programme/additional-research/measures-of-the-stance-ofunited-states-monetary-policy.

Meier, S. 2013. "Financial Globalization and Monetary Transmission." Working Paper No. 145. Globalization and Monetary Policy Institute. Federal Reserve Bank of Dallas.

Obstfeld, M. 2015. "Trilemma and Tradeoffs: Living with Financial Globalization.” BIS Working Paper Series No. 480. Bank for International Settlements. Basel.

Rey, H. 2015. "Dilemma Not Trilemma: The Global Financial Cycle and Monetary Policy Independence.” NBER Working Paper No. 21162. National Bureau of Economic Research. Cambridge, MA.

Taylor, J. 1993. "Discretion versus Policy Rules in Practice." Carnegie-Rochester Conference Series on Public Policy 39: 195-214.

Tong, H., and S.-J. Wei. 2011. "The Composition Matters: Capital Inflows and Liquidity Crunch During a Global Economic Crisis." Review of Financial Studies 24(6): 20232052 .

Wu, J. C., and F. D. Xia. 2016. "Measuring the Macroeconomic Impact of Monetary Policy at the Zero Lower Bound." Journal of Money, Credit and Banking 48(2-3): 253-291. 
Table 1: Coefficients for different combinations of regimes

\begin{tabular}{l|c|c}
\hline & Without Capital Controls & With Capital Controls \\
\hline Fixed Exchange Rate Regime & $\beta_{1}$ & $\beta_{2}$ \\
\hline Flexible Exchange Rate Regime & $\beta_{3}$ & $\beta_{4}$ \\
\hline
\end{tabular}

Table 2: Country classifications in the baseline case

\begin{tabular}{|c|c|c|}
\hline & Without Capital Controls & With Capital Controls \\
\hline $\begin{array}{l}\text { Fixed Exchange Rate } \\
\text { Regime }\end{array}$ & $\begin{array}{l}\text { Hong Kong, China, (199905- } \\
\text { 200904) } \\
\text { Ecuador, (200704-200810) } \\
\text { Israel, (200604-200904) }\end{array}$ & $\begin{array}{l}\text { Argentina, (199905-200109) } \\
\text { China, People's Rep. of, (199905- } \\
\text { 200109) } \\
\text { Ecuador, (200109-200604;200904) } \\
\text { Israel, (200404-200509) } \\
\text { Korea, Republic of, (200404-200904) } \\
\text { Pakistan, (200404-200904) }\end{array}$ \\
\hline $\begin{array}{l}\text { Flexible Exchange } \\
\text { Rate Regime }\end{array}$ & \begin{tabular}{|l} 
Canada, (199905-200904) \\
Chile, (200504-200710) \\
Germany, (199905-200904) \\
Japan, (200005-200904) \\
New Zealand, (199909- \\
200904) \\
Peru, (199909-200904) \\
Singapore, (200204-200904) \\
United Kingdom, (199905- \\
200904)
\end{tabular} & $\begin{array}{l}\text { Argentina, (200309-200904) } \\
\text { Australia, (199905-200904) } \\
\text { Belarus, (200109-200904) } \\
\text { Bolivia, (199905-200904) } \\
\text { Brazil, (200005-200904) } \\
\text { Chile, (199905-200904) } \\
\text { China, People's Rep. of, (200204- } \\
\text { 200904) } \\
\text { Colombia, (199905-200904) } \\
\text { Costa Rica, (199905-200904) } \\
\text { India, (199905-200904) } \\
\text { Indonesia, (199909-200904) } \\
\text { Israel, (199905-200309) } \\
\text { Japan, (199905-199909) } \\
\text { Korea, Republic of, (199905-200309) } \\
\text { Mexico, (200810-200904) } \\
\text { Pakistan, (199905-200309) } \\
\text { Philippines, (199905-200904) } \\
\text { South Africa, (199905-200904) } \\
\text { Thailand, (200009-200904) } \\
\text { Turkey, (199909-200904) }\end{array}$ \\
\hline
\end{tabular}

Note: The classifications are based on de facto exchange rate regime classification as coded by Ilzetzki et al. (2010) and financial openness by Chinn-Ito (2008). 
Table 3: Baseline model for both short-term policy rates and long-term government bond yields

\begin{tabular}{|c|c|c|c|c|c|c|}
\hline & & $\begin{array}{c}\text { Short-term } \\
\text { 1990-2009 } \\
\text { (1) }\end{array}$ & $\begin{array}{c}\text { Short-term } \\
1990-1998^{1} \\
\text { (2) }\end{array}$ & $\begin{array}{c}\text { Short-term } \\
\text { 1999-2009 } \\
\text { (3) }\end{array}$ & $\begin{array}{c}\text { Short-term } \\
\text { Without Argentina } \\
\text { 2001/April } \\
(4) \\
\end{array}$ & $\begin{array}{c}\text { Long-term } \\
\text { 1999-2009 } \\
\text { (5) }\end{array}$ \\
\hline$i_{i, t-1}^{p}$ & $\lambda$ & $\begin{array}{c}-\mathbf{0 . 0 4 8 *} \\
(0.008)\end{array}$ & $\begin{array}{l}-0.007 \\
(0.015)\end{array}$ & $\begin{array}{c}-\mathbf{0 . 1 1 0} * \\
(0.01)\end{array}$ & $\begin{array}{r}-\mathbf{0 . 1 1 *} \\
(0.01)\end{array}$ & $\begin{array}{c}-\mathbf{0 . 0 6 8 *} \\
(0.02)\end{array}$ \\
\hline$\Delta G D P$ growth $_{i, t}$ & $\phi_{1}$ & $\begin{array}{l}0.096 \\
(0.06)\end{array}$ & $\begin{array}{c}0.237 \\
(0.144)\end{array}$ & $\begin{array}{c}0.041 \\
(0.054)\end{array}$ & $\begin{array}{l}0.044 \\
(0.053)\end{array}$ & $\begin{array}{c}\mathbf{0 . 0 6 4} * \\
(0.03)\end{array}$ \\
\hline$\Delta$ Inflation $_{i, t}$ & $\phi_{2}$ & $\begin{array}{l}0.329 * \\
(0.048)\end{array}$ & $\begin{array}{c}0.134 \\
(0.096)\end{array}$ & $\begin{array}{l}\mathbf{0 . 4 1 3 *} \\
(0.049)\end{array}$ & $\begin{array}{l}\mathbf{0 . 4 1 3 *} \\
(0.049)\end{array}$ & $\begin{array}{c}\mathbf{0 . 1 6 2} * \\
(0.05)\end{array}$ \\
\hline$D_{\text {fixed.NC }} \Delta r_{i, t}^{U S}$ & $\beta_{1}$ & $\begin{array}{c}0.649 * \\
(0.39)\end{array}$ & $\begin{array}{l}0.402 \\
(2.09)\end{array}$ & $\begin{array}{c}\mathbf{0 . 6 5 4} * \\
(0.3)\end{array}$ & $\begin{array}{l}\mathbf{0 . 6 4 8 *} \\
(0.297)\end{array}$ & $\begin{array}{c}\mathbf{0 . 6 8 0 *} \\
(0.31)\end{array}$ \\
\hline$D_{\text {fixed.c }} \Delta r_{i, t}^{U S}$ & $\beta_{2}$ & $\begin{array}{c}0.034 \\
(0.325)\end{array}$ & $\begin{array}{c}1.998 \\
(1.286)\end{array}$ & $\begin{array}{l}-0.249 \\
(0.258)\end{array}$ & $\begin{array}{r}-0.047 \\
(0.262)\end{array}$ & $\begin{array}{c}0.34 \\
(0.52)\end{array}$ \\
\hline$D_{\text {flex.NC }} \Delta r_{i, t}^{U S}$ & $\beta_{3}$ & $\begin{array}{l}\mathbf{0 . 4 5 0 *} \\
(0.176)\end{array}$ & $\begin{array}{c}0.492 \\
(0.438)\end{array}$ & $\begin{array}{l}\mathbf{0 . 4 9 7 *} \\
(0.154)\end{array}$ & $\begin{array}{c}\mathbf{0 . 4 9 3 *} \\
(0.153)\end{array}$ & $\begin{array}{c}\mathbf{0 . 4 0 7 *} \\
(0.13)\end{array}$ \\
\hline$D_{\text {flex.c }} \Delta r_{i, t}^{U S}$ & $\beta_{4}$ & $\begin{array}{c}0.029 \\
(0.127)\end{array}$ & $\begin{array}{c}0.008 \\
(0.334)\end{array}$ & $\begin{array}{l}0.063 \\
(0.11)\end{array}$ & $\begin{array}{l}0.059 \\
(0.109)\end{array}$ & $\begin{array}{c}0.12 \\
(0.13)\end{array}$ \\
\hline$\Delta V I X_{t}$ & $\delta$ & $\begin{array}{c}0.23 \\
(0.199) \\
\end{array}$ & $\begin{array}{c}0.086 \\
(0.584) \\
\end{array}$ & $\begin{array}{c}0.176 \\
(0.169) \\
\end{array}$ & $\begin{array}{l}0.172 \\
(0.168) \\
\end{array}$ & $\begin{array}{c}0.14 \\
(0.10) \\
\end{array}$ \\
\hline $\begin{array}{l}\text { F test: }{ }^{2} \beta_{2}=\beta_{4} \\
\text { F test: } \beta_{4}=\beta_{3}\end{array}$ & & $\begin{array}{c}1.33 \\
\mathbf{4 . 0 7 *}\end{array}$ & $\begin{array}{l}1.26 \\
0.82\end{array}$ & $\begin{array}{l}0.23 * \\
5.79 *\end{array}$ & $\begin{array}{c}0.23 \\
5.96 *\end{array}$ & $\begin{array}{l}0.00 \\
2.62\end{array}$ \\
\hline $\begin{array}{l}\text { Adjusted R-squared } \\
\text { No. of Obs. }\end{array}$ & & $\begin{array}{l}0.09 \\
827\end{array}$ & $\begin{array}{c}0.000^{3} \\
295\end{array}$ & $\begin{array}{l}0.30 \\
532 \\
\end{array}$ & $\begin{array}{l}0.30 \\
531 \\
\end{array}$ & $\begin{array}{l}0.20 \\
301\end{array}$ \\
\hline
\end{tabular}

1 For 1990-1998, there is only one country/quarter observed for the regime of fixed exchange rate and no capital controls (HKG 1998 Oct).

$2 \quad \mathrm{~F}=\frac{\left(\mathrm{R}_{\mathrm{UR}}^{2}-\mathrm{R}_{\mathrm{R}}^{2}\right)}{\text { no }} / \frac{\left(1-\mathrm{R}_{\mathrm{UR}}^{2}\right)}{\text { restrictions }}$

3 The unadjusted R-squared is 0.0272. 
Table 4: Asymmetric responses under flexible exchange rate regimes plus an alternative Taylor rule specification

\begin{tabular}{|c|c|c|c|c|c|c|}
\hline & & $\begin{array}{c}(1) \\
\text { Asymmetric } \\
\text { responses } \\
\text { under } \\
\text { flexible } \\
\text { exchange } \\
\text { rates }\end{array}$ & $\begin{array}{c}(2) \\
\text { Country } \\
\text { specific } \\
\text { Taylor } \\
\text { rules }\end{array}$ & $\begin{array}{c}\text { (3) } \\
\text { Adding } \\
\text { exchange } \\
\text { rate } \\
\text { stability to } \\
\text { Taylor rule }\end{array}$ & $\begin{array}{l}\text { Combining } \\
\text { (2) and (3) }\end{array}$ & $\begin{array}{c}\text { (5) } \\
\text { Long-term } \\
\text { bond yield } \\
\text { as } \\
\text { dependent } \\
\text { variable }\end{array}$ \\
\hline$i_{i, t-1}^{p}$ & $\lambda$ & $\begin{array}{c}-\mathbf{0 . 1 1 4} * \\
(0.01)\end{array}$ & $\begin{array}{c}-\mathbf{0 . 1 0 6} * \\
(0.01)\end{array}$ & $\begin{array}{c}-\mathbf{0 . 1 1 7} * \\
(0.01)\end{array}$ & $\begin{array}{c}-\mathbf{0 . 1 1 1} * \\
(0.01)\end{array}$ & $\begin{array}{c}-\mathbf{0 . 0 6 7} * \\
(0.017)\end{array}$ \\
\hline$\Delta G D P$ growt $_{i, t}$ & $\phi_{1}$ & $\begin{array}{c}0.04 \\
(0.053)\end{array}$ & $\begin{array}{c}\text { not } \\
\text { reported }\end{array}$ & $\begin{array}{c}0.064 \\
(0.055)\end{array}$ & $\begin{array}{c}\text { not } \\
\text { reported }\end{array}$ & $\begin{array}{l}\mathbf{0 . 0 7 5 *} \\
(0.032)\end{array}$ \\
\hline$\Delta$ Inflation $_{i, t}$ & $\phi_{2}$ & $\begin{array}{l}\mathbf{0 . 4 1 3} * \\
(0.049)\end{array}$ & $\begin{array}{c}\text { not } \\
\text { reported }\end{array}$ & $\begin{array}{l}\text { 2.442* } \\
(1.137)\end{array}$ & $\begin{array}{c}\text { not } \\
\text { reported }\end{array}$ & $\begin{array}{l}1.207 * \\
(0.674)\end{array}$ \\
\hline$\Delta$ Real ExchangeRate $_{i, t}$ & $\phi_{3}$ & $\begin{array}{l}- \\
-\end{array}$ & $\begin{array}{l}- \\
-\end{array}$ & $\begin{array}{c}\mathbf{2 . 0 3 *} \\
(1.136)\end{array}$ & $\begin{array}{c}\text { not } \\
\text { reported }\end{array}$ & $\begin{array}{c}1.053 \\
(0.677)\end{array}$ \\
\hline$D_{\text {fixed.NC }} \Delta r_{i, t}^{U S}$ & $\beta_{1}$ & $\begin{array}{l}\mathbf{0 . 6 5 6 *} \\
(0.298)\end{array}$ & $\begin{array}{l}\mathbf{0 . 7 6 5 *} \\
(0.322)\end{array}$ & $\begin{array}{l}\mathbf{0 . 6 1 7} \text { * } \\
(0.298)\end{array}$ & $\begin{array}{l}\mathbf{0 . 7 2 6} \text { * } \\
(0.321)\end{array}$ & $\begin{array}{l}\mathbf{0 . 6 7 4 *} \\
(0.313)\end{array}$ \\
\hline$D_{\text {fixed.C }} \Delta r_{i, t}^{U S}$ & $\beta_{2}$ & $\begin{array}{l}-0.048 \\
(0.262)\end{array}$ & $\begin{array}{l}-0.041 \\
(0.258)\end{array}$ & $\begin{array}{l}-0.039 \\
(0.261)\end{array}$ & $\begin{array}{l}-0.014 \\
(0.257)\end{array}$ & $\begin{array}{c}0.4 \\
(0.524)\end{array}$ \\
\hline$D_{\text {flex.NC}}$ Pos $\Delta r_{i, t}^{U S}$ & $\beta_{3, p o s}$ & $\begin{array}{c}0.152 \\
(0.314)\end{array}$ & $\begin{array}{c}0.172 \\
(0.302)\end{array}$ & $\begin{array}{c}0.114 \\
(0.314)\end{array}$ & $\begin{array}{c}0.117 \\
(0.302)\end{array}$ & $\begin{array}{c}0.348 \\
(0.262)\end{array}$ \\
\hline$D_{f l e x . N C} N e g \Delta r_{i, t}^{U S}$ & $\beta_{3, \text { neg }}$ & $\begin{array}{c}\mathbf{0 . 6 3 *} \\
(0.196)\end{array}$ & $\begin{array}{c}\mathbf{0 . 4 9 6 *} \\
(0.22)\end{array}$ & $\begin{array}{l}\mathbf{0 . 6 1 6} \\
(0.196)\end{array}$ & $\begin{array}{c}\mathbf{0 . 4 7 *} \\
(0.219)\end{array}$ & $\begin{array}{c}\mathbf{0 . 3 9 6 *} \\
(0.19)\end{array}$ \\
\hline$D_{\text {flex.C }}$ Pos $\Delta r_{i, t}^{U S}$ & $\beta_{4, p o s}$ & $\begin{array}{c}0.215 \\
(0.244)\end{array}$ & $\begin{array}{c}0.224 \\
(0.244)\end{array}$ & $\begin{array}{c}0.192 \\
(0.244)\end{array}$ & $\begin{array}{c}0.185 \\
(0.243)\end{array}$ & $\begin{array}{l}-0.084 \\
(0.252)\end{array}$ \\
\hline$D_{\text {flex.C }} N e g \Delta r_{i, t}^{U S}$ & $\beta_{4, \text { neg }}$ & $\begin{array}{c}0.013 \\
(0.146)\end{array}$ & $\begin{array}{c}0.037 \\
(0.149)\end{array}$ & $\begin{array}{c}0.025 \\
(0.145)\end{array}$ & $\begin{array}{c}0.042 \\
(0.148)\end{array}$ & $\begin{array}{c}0.213 \\
(0.185)\end{array}$ \\
\hline$\Delta V I X_{t}$ & $\delta$ & $\begin{array}{c}0.172 \\
(0.169) \\
\end{array}$ & $\begin{array}{c}\text { 0.329* } \\
(0.17)\end{array}$ & $\begin{array}{c}0.047 \\
(0.183) \\
\end{array}$ & $\begin{array}{c}0.175 \\
(0.182) \\
\end{array}$ & $\begin{array}{c}0.069 \\
(0.107) \\
\end{array}$ \\
\hline Adjusted R-squared & & 0.30 & 0.38 & 0.31 & 0.39 & 0.20 \\
\hline No. of Obs. & & 531 & 531 & 531 & 531 & 301 \\
\hline
\end{tabular}

Note: Country specific coefficients for the Taylor rule variables are incorporated in Specifications (2) and (4) but not reported to save space. 
Table 5: Including the lower-bound episode (1999-2012); Sensitivity analysis with different initial values

\begin{tabular}{|c|c|c|c|c|c|c|c|}
\hline & & $\begin{array}{l}\text { Using OLS } \\
\text { est. as the } \\
\text { initial values } \\
\text { (1) }\end{array}$ & $\begin{array}{c}\text { Initial values in } \\
(1)+\text { Standard } \\
\text { Error (SE) } \\
(2)\end{array}$ & $\begin{array}{l}\text { Initial } \\
\text { values in } \\
(1)+ \\
2 * \mathrm{SE} \\
(3)\end{array}$ & $\begin{array}{l}\text { Initial } \\
\text { values in } \\
(1)- \\
\text { SE } \\
(4)\end{array}$ & $\begin{array}{l}\text { Initial } \\
\text { values in } \\
(1)- \\
2 * \mathrm{SE} \\
(5)\end{array}$ & $\begin{array}{l}\text { Initial values (OLS } \\
\text { estimate) from the } \\
\text { baseline } \\
\text { optimization } \\
\text { (6) }\end{array}$ \\
\hline$i_{i, t-1}^{p}$ & $\lambda$ & $-0.11 *$ & $-0.11 *$ & $-0.11 *$ & $-0.11 *$ & $-0.11^{*}$ & $-0.11^{*}$ \\
\hline$\triangle G D P$ growth $_{i, t}$ & $\phi_{1}$ & $0.06 *$ & $0.06 *$ & $0.06 *$ & $0.06 *$ & $0.06 *$ & 0.06 \\
\hline$\Delta$ Inflation $_{i, t}$ & $\phi_{2}$ & $2.60 *$ & $2.39 *$ & $2.45 *$ & $2.38 *$ & $2.42^{*}$ & $2.48 *$ \\
\hline$\Delta{\text { Real Exchange } \text { Rate }_{i, t}}$ & $\phi_{3}$ & $2.23 *$ & $2.02 *$ & $2.08 *$ & $2.01 *$ & $2.05 *$ & $2.11^{*}$ \\
\hline$D_{\text {fixed.NC }} \Delta r_{i, t}^{U S}$ & $\beta_{1}$ & $0.52 *$ & $0.50 \%$ & $0.51 *$ & $0.51 *$ & $0.51 *$ & $0.57 *$ \\
\hline$D_{\text {fixed.c }} \Delta r_{i, t}^{U S}$ & $\beta_{2}$ & -0.05 & -0.07 & -0.05 & -0.06 & -0.06 & -0.11 \\
\hline$D_{\text {flex.NC}} \operatorname{Pos} \Delta r_{i, t}^{U S}$ & $\beta_{3, p o s}$ & $0.18 *$ & $0.20 *$ & $0.18 *$ & $0.20 *$ & $0.19 *$ & 0.25 \\
\hline$D_{f l e x . N C} N e g \Delta r_{i, t}^{U S}$ & $\beta_{3, \text { neg }}$ & $0.60 *$ & $0.58 *$ & $0.60 *$ & $0.57 *$ & $0.59 *$ & $0.54 *$ \\
\hline$D_{\text {flex } . C} P o s \Delta r_{i, t}^{U S}$ & $\beta_{4, p o s}$ & 0.22 & 0.23 & 0.21 & 0.23 & 0.22 & 0.26 \\
\hline$D_{\text {flex.C }} N e g \Delta r_{i, t}^{U S}$ & $\beta_{4, n e g}$ & 0.04 & 0.02 & 0.05 & 0.02 & 0.04 & 0.002 \\
\hline$\Delta V I X_{t}$ & $\delta$ & $0.16 *$ & $0.19 *$ & $0.16 *$ & $0.19 *$ & $0.17 *$ & 0.16 \\
\hline$\sigma_{\varepsilon}$ & & 2.51 & 2.81 & 2.60 & 2.66 & 2.68 & 1.07 \\
\hline $\log M_{t}$ & $\theta_{2}$ & -0.17 & -10.60 & -0.15 & -12.18 & -5.67 & 0 \\
\hline $\log Y_{t}$ & $\theta_{3}$ & 0.16 & 9.97 & 0.14 & 11.45 & 5.33 & 0 \\
\hline$\sigma_{\epsilon_{\mathrm{t}}}$ & & 0.005 & 0.32 & 0.004 & 0.37 & 0.17 & 1.07 \\
\hline Log L at optimal & & -1505.719 & -1505.997 & -1505.700 & -1506.070 & -1505.814 & - \\
\hline Obs. & & 736 & 736 & 736 & 736 & 736 & \\
\hline
\end{tabular}

Note: Columns (1)-(5) are results using different initial values for the optimization. More specifically, Column (1) uses the OLS estimate as the initial values. Columns (2) and (3) use the coefficients in Column (1) plus 1 and 2 standard errors as the initial values, respectively, while Columns (4) and (5) use the coefficients in Column (1) minus 1 and 2 standard errors as the initial values. Column (6) presents the OLS estimates for the monetary policy equation (baseline estimates as in Table 3) and for the money supply equation using the above-lower-bound data. 
Table 6: Additional robustness checks (M1 1999 to M3 2009)

\begin{tabular}{|c|c|c|c|c|c|c|c|}
\hline & \multicolumn{2}{|c|}{$\begin{array}{c}\text { Re-defining capital } \\
\text { controls as continuous } \\
\text { variable as }(0,1]\end{array}$} & & \multicolumn{2}{|c|}{$\begin{array}{c}\text { Re-defining nominal } \\
\text { exchange rate regime by } \\
\text { AREAER }\end{array}$} & \multicolumn{2}{|c|}{$\begin{array}{c}\text { Using pre-assigned Taylor } \\
\text { Rule }\end{array}$} \\
\hline & $\begin{array}{c}\text { Short-term } \\
\text { (1) }\end{array}$ & $\begin{array}{l}\text { Long-term } \\
\text { (2) }\end{array}$ & & $\begin{array}{l}\text { Short-term } \\
\text { (3) }\end{array}$ & $\begin{array}{l}\text { Long-term } \\
\text { (4) }\end{array}$ & $\begin{array}{l}\text { Short-term } \\
\text { (5) }\end{array}$ & $\begin{array}{l}\text { Long-term } \\
\text { (6) }\end{array}$ \\
\hline$i_{i, t-1}^{p}$ & $\begin{array}{c}-\mathbf{0 . 1 1 4} * \\
(0.01)\end{array}$ & $\begin{array}{l}-\mathbf{0 . 0 6 *} \\
(0.017)\end{array}$ & $i_{i, t-1}^{p}$ & $\begin{array}{c}-\mathbf{0 . 1 1 6 *} \\
(0.01)\end{array}$ & $\begin{array}{c}-\mathbf{0 . 0 6 6 *} \\
(0.017)\end{array}$ & $\begin{array}{c}-\mathbf{0 . 1 1 3 *} \\
(0.01)\end{array}$ & $\begin{array}{l}-\mathbf{0 . 0 6 2 *} \\
(0.016)\end{array}$ \\
\hline$\triangle G D P$ growth $_{i, t}$ & $\begin{array}{c}0.065 \\
(0.056)\end{array}$ & $\begin{array}{l}\mathbf{0 . 0 7 8 *} \\
(0.032)\end{array}$ & $\triangle G D P$ growth $_{i, t}$ & $\begin{array}{r}0.065 \\
(0.055)\end{array}$ & $\begin{array}{l}\mathbf{0 . 0 7 6 *} \\
(0.032)\end{array}$ & $\begin{array}{c}0.053 \\
-\end{array}$ & $\begin{array}{c}0.070 * \\
-\end{array}$ \\
\hline$\Delta$ Inflation $_{i, t}$ & $\begin{array}{l}\mathbf{2 . 5 2 2 *} \\
(1.147)\end{array}$ & $\begin{array}{l}1.176^{*} \\
(0.671)\end{array}$ & $\Delta$ Inflation $_{i, t}$ & $\begin{array}{l}\mathbf{2 . 5 3 6 *} \\
(1.139)\end{array}$ & $\begin{array}{l}1.183^{*} \\
(0.672)\end{array}$ & $\begin{array}{c}0.158 \\
-\end{array}$ & $\begin{array}{c}0.209 * \\
-\end{array}$ \\
\hline$\Delta$ Real Exchange Rate $_{i, t}$ & $\begin{array}{l}2.102 * \\
(1.146)\end{array}$ & $\begin{array}{c}1.03 \\
(0.674)\end{array}$ & $\Delta{\text { Real Exchange } \text { Rate }_{i, t}}$ & $\begin{array}{l}\mathbf{2 . 1 2 2 *} \\
(1.138)\end{array}$ & $\begin{array}{c}1.028 \\
(0.676)\end{array}$ & $\begin{array}{c}-0.25 \\
(0.175)\end{array}$ & $\begin{array}{c}0.054 \\
(0.116)\end{array}$ \\
\hline$D_{\text {fixed. }} \Delta r_{i, t}^{U S}$ & $\begin{array}{l}\mathbf{0 . 4 8 7 *} \\
(0.271)\end{array}$ & $\begin{array}{c}\mathbf{0 . 6 6 3 *} \\
(0.31)\end{array}$ & $D_{\text {fixed.NC }} \Delta r_{i, t}^{U S}$ & $\begin{array}{l}\mathbf{0 . 5 8 2 *} \\
(0.346)\end{array}$ & $\begin{array}{l}\mathbf{0 . 6 7 1 *} \\
(0.313)\end{array}$ & $\begin{array}{l}\mathbf{0 . 6 4 5 *} \\
(0.299)\end{array}$ & $\begin{array}{l}\mathbf{0 . 6 8 5 *} \\
(0.313)\end{array}$ \\
\hline$D_{\text {fixed }} \Delta r_{i, t}^{U S} * C$ & $\begin{array}{l}-0.727 \\
(0.546)\end{array}$ & $\begin{array}{l}-0.454 \\
(1.139)\end{array}$ & $D_{\text {fixed.C }} \Delta r_{i, t}^{U S}$ & $\begin{array}{l}-0.131 \\
(0.271)\end{array}$ & $\begin{array}{l}-0.307 \\
(0.645)\end{array}$ & $\begin{array}{c}-0.06 \\
(0.262)\end{array}$ & $\begin{array}{c}0.353 \\
(0.525)\end{array}$ \\
\hline$D_{\text {flex }}$ Pos $\Delta r_{i, t}^{U S}$ & $\begin{array}{c}0.098 \\
(0.285)\end{array}$ & $\begin{array}{c}0.392 \\
(0.241)\end{array}$ & $D_{\text {flex.NC}} \operatorname{Pos} \Delta r_{i, t}^{U S}$ & $\begin{array}{c}0.116 \\
(0.309)\end{array}$ & $\begin{array}{c}0.363 \\
(0.263)\end{array}$ & $\begin{array}{c}0.154 \\
(0.314)\end{array}$ & $\begin{array}{l}0.395 \\
(0.26)\end{array}$ \\
\hline$D_{f l e x} N e g \Delta r_{i, t}^{U S}$ & $\begin{array}{l}\mathbf{0 . 3 6 9 *} \\
(0.173)\end{array}$ & $\begin{array}{l}\mathbf{0 . 3 6 5 *} \\
(0.177)\end{array}$ & $D_{\text {flex.NC }} N e g \Delta r_{i, t}^{U S}$ & $\begin{array}{l}\mathbf{0 . 6 3 7 *} \\
(0.191)\end{array}$ & $\begin{array}{l}\mathbf{0 . 3 8 5 *} \\
(0.191)\end{array}$ & $\begin{array}{l}\mathbf{0 . 6 1 8 *} \\
(0.196)\end{array}$ & $\begin{array}{c}\mathbf{0 . 4 1 5 *} \\
(0.19)\end{array}$ \\
\hline$D_{\text {flex }}$ Pos $\Delta r_{i, t}^{U S} * C$ & $\begin{array}{c}0.218 \\
(0.504)\end{array}$ & $\begin{array}{l}-\mathbf{0 . 9 5} * \\
(0.493)\end{array}$ & $D_{\text {flex.C }} \operatorname{Pos} \Delta r_{i, t}^{U S}$ & $\begin{array}{c}0.125 \\
(0.246)\end{array}$ & $\begin{array}{l}-0.032 \\
(0.248)\end{array}$ & $\begin{array}{c}0.212 \\
(0.244)\end{array}$ & $\begin{array}{l}-0.084 \\
(0.253)\end{array}$ \\
\hline$D_{\text {flex }} N e g \Delta r_{i, t}^{U S} * C$ & -0.451 & -0.205 & $D_{\text {flex.C }} N e g \Delta r_{i, t}^{U S}$ & 0.074 & 0.232 & -0.001 & 0.233 \\
\hline
\end{tabular}




\begin{tabular}{l|cc|l|cc|cc}
\hline & $(0.303)$ & $(0.346)$ & & $(0.146)$ & $(0.188)$ & $(0.145)$ & $(0.185)$ \\
$\Delta V I X_{t}$ & 0.036 & 0.073 & $\Delta V I X_{t}$ & 0.035 & 0.077 & 0.183 & 0.139 \\
& $(0.184)$ & $(0.106)$ & & $(0.182)$ & $(0.107)$ & $(0.171)$ & $(0.096)$ \\
\hline Adjusted R-squared & 0.30 & 0.20 & Adjusted R-squared & 0.31 & 0.20 & 0.30 & 0.20 \\
No. of Obs. & 531 & 301 & No. of Obs. & 531 & 301 & 531 & 301 \\
\hline Notes: &
\end{tabular}

(1) * denotes "statistically significant at 10\%."

(2) The coefficient estimate for changes in desired policy rate in the case of short-term policy rate (Column 5) is 0.105 with a standard error of 0.110 ; The coefficients for the output gap and inflation gaps are $0.105 \times 0.5=0.053$ and $0.105 \times 1.5=0.158$, respectively. The coefficient estimates in the case of long-term interest rate (Column 6) is 0.139 with a standard error of 0.060 . The corresponding coefficients for the output and inflation gaps are $0.139 \times 0.5=0.070$ and $0.139 \times 1.5=0.209$, respectively. 
Table 7: Seemingly Unrelated Regressions

\begin{tabular}{|c|c|c|c|c|c|}
\hline & & $\begin{array}{c}\text { Fixed exchange rate } \\
\text { without capital } \\
\text { controls } \\
\end{array}$ & $\begin{array}{l}\text { Fixed exchange rate } \\
\text { with capital controls }\end{array}$ & $\begin{array}{c}\text { Flexible exchange } \\
\text { rate without capital } \\
\text { controls }\end{array}$ & $\begin{array}{c}\text { Flexible exchange } \\
\text { rate with capital } \\
\text { controls } \\
\end{array}$ \\
\hline \multirow[t]{2}{*}{$i_{i, t-1}^{p}$} & $\lambda$ & 0.02 & $-0.046 *$ & $-0.115^{*}$ & $-0.112 *$ \\
\hline & & $(0.02)$ & $(0.015)$ & $(0.067)$ & $(0.034)$ \\
\hline \multirow[t]{2}{*}{$\triangle G D P$ growth $_{i, t}$} & $\phi_{1}$ & $0.114^{*}$ & 0.028 & 0.107 & 0.042 \\
\hline & & $(0.037)$ & $(0.039)$ & $(0.087)$ & $(0.115)$ \\
\hline \multirow[t]{2}{*}{$\Delta$ Inflation $_{i, t}$} & $\phi_{2}$ & $0.099 *$ & $0.385 *$ & $0.35 *$ & $0.431 *$ \\
\hline & & $(0.028)$ & $(0.05)$ & $(0.113)$ & $(0.138)$ \\
\hline \multirow[t]{2}{*}{$D_{P o s} \Delta r_{i, t}^{U S}$} & $\beta_{\text {pos }}$ & $1.034^{*}$ & -0.032 & 0.243 & 0.304 \\
\hline & & $(0.058)$ & $(0.122)$ & $(0.16)$ & $(0.25)$ \\
\hline \multirow[t]{2}{*}{$D_{N e g} \Delta r_{i, t}^{U S}$} & $\beta_{\text {neg }}$ & $0.527 *$ & 0.056 & $0.497 *$ & -0.026 \\
\hline & & $(0.07)$ & $(0.093)$ & $(0.134)$ & $(0.168)$ \\
\hline \multirow[t]{2}{*}{$\Delta V I X_{t}$} & $\delta$ & $-0.259 *$ & 0.08 & -0.029 & 0.427 \\
\hline & & $(0.13)$ & $(0.163)$ & $(0.101)$ & $(0.293)$ \\
\hline
\end{tabular}


Table 8: Comparisons with Obstfeld (2015) and Georgiadis and Mehl (2015)

\begin{tabular}{|c|c|c|c|c|}
\hline & & $\begin{array}{c}\text { Compared with } \\
\text { Obstfeld (2015): } \\
\text { including Euro } \\
\text { Economies: 1990-2009 } \\
\text { (1) }\end{array}$ & $\begin{array}{c}\text { Compared with } \\
\text { Obstfeld (2015): } \\
\text { including Euro } \\
\text { Economies: 1999-2009 } \\
(2) \\
\end{array}$ & $\begin{array}{c}\text { Compared with } \\
\text { Georgiadis and Mehl } \\
\text { (2015): including Euro } \\
\text { Economies: } 1999-2009 \\
\text { (3) } \\
\end{array}$ \\
\hline$i_{i, t-1}^{p}$ & $\lambda$ & $\begin{array}{c}-\mathbf{0 . 0 5 1 *} \\
(0.01)\end{array}$ & $\begin{array}{c}-\mathbf{0 . 1 0 5 *} \\
(0.01)\end{array}$ & $\begin{array}{c}\mathbf{0 . 1 0 5 *} \\
(0.01)\end{array}$ \\
\hline$\triangle G D P$ growth $_{i, t}$ & $\phi_{1}$ & $\begin{array}{l}\mathbf{0 . 1 2 2 *} \\
(0.04)\end{array}$ & $\begin{array}{c}0.05 \\
(0.04)\end{array}$ & $\begin{array}{c}0.05 \\
(0.04)\end{array}$ \\
\hline$\Delta$ Inflation $_{i, t}$ & $\phi_{2}$ & $\begin{array}{c}\mathbf{0 . 2 9 3} * \\
(0.03)\end{array}$ & $\begin{array}{c}\mathbf{0 . 3 8 5 *} \\
(0.04)\end{array}$ & $\begin{array}{l}\mathbf{0 . 3 8 4} * \\
(0.04)\end{array}$ \\
\hline$D_{\text {fixed.NC }} \Delta r_{i, t}^{U S}$ & $\beta_{1}$ & $\begin{array}{c}\mathbf{0 . 6 1 4} * \\
(0.32)\end{array}$ & $\begin{array}{c}\mathbf{0 . 6 4 1 *} \\
(0.26)\end{array}$ & $\begin{array}{c}\mathbf{0 . 6 7 5} * \\
(0.30)\end{array}$ \\
\hline$D_{\text {fixed.C }} \Delta r_{i, t}^{U S}$ & $\beta_{2}$ & $\begin{array}{l}-0.03 \\
(0.26)\end{array}$ & $\begin{array}{l}-0.23 \\
(0.21)\end{array}$ & $\begin{array}{l}-0.21 \\
(0.23)\end{array}$ \\
\hline$D_{\text {flex.NC }} \Delta r_{i, t}^{U S}$ & $\beta_{3}$ & $\begin{array}{l}\mathbf{0 . 2 3 6 *} \\
(0.11)\end{array}$ & $\begin{array}{l}\mathbf{0 . 2 8 8 *} \\
(0.10)\end{array}$ & $\begin{array}{c}\mathbf{0 . 3 0 7 *} \\
(0.13)\end{array}$ \\
\hline$D_{\text {flex.C }} \Delta r_{i, t}^{U S}$ & $\beta_{4}$ & $\begin{array}{l}-0.04 \\
(0.08)\end{array}$ & $\begin{array}{c}0.01 \\
(0.08)\end{array}$ & $\begin{array}{c}0.03 \\
(0.10)\end{array}$ \\
\hline$\Delta V I X_{t}$ & $\delta$ & $\begin{array}{l}\mathbf{0 . 2 3 1}^{*} \\
(0.13)\end{array}$ & $\begin{array}{l}\text { 0.218* } \\
(0.12)\end{array}$ & $\begin{array}{l}\mathbf{0 . 2 1 8 *} \\
(0.12)\end{array}$ \\
\hline$F X$ reserve $* \Delta r_{i, t}^{U S}$ & & & & $\begin{array}{l}-0.06 \\
(0.23)\end{array}$ \\
\hline $\begin{array}{l}\text { Adjusted R-squared } \\
\text { No. of Obs. }\end{array}$ & & $\begin{array}{l}0.10 \\
1403 \\
\end{array}$ & $\begin{array}{l}0.28 \\
844 \\
\end{array}$ & $\begin{array}{l}0.28 \\
844 \\
\end{array}$ \\
\hline
\end{tabular}


Table 9: Exchange Rate Changes as the Dependent Variable

\begin{tabular}{|c|c|c|c|c|c|}
\hline & & $\begin{array}{c}\text { (1) } \\
\text { With estimated Taylor } \\
\text { Rule } \\
\end{array}$ & $\begin{array}{l}\quad(2) \\
\text { With pre-assigned } \\
\text { Taylor Rule } \\
\end{array}$ & $\begin{array}{c}(3) \\
\text { With estimated } \\
\text { Taylor Rule } \\
\end{array}$ & $\begin{array}{c}\quad(4) \\
\text { With pre-assigned } \\
\text { Taylor Rule } \\
\end{array}$ \\
\hline \multirow[t]{2}{*}{$\Delta \log E_{x c h a n g e R} e_{\mathrm{i}, \mathrm{t}-1}$} & $\lambda$ & - & - & $0.127 *$ & $0.2 *$ \\
\hline & & - & - & $(0.036)$ & $(0.036)$ \\
\hline$\triangle G D P$ growth $_{i, t}$ & $\phi_{1}$ & $\begin{array}{c}-\mathbf{0 . 0 1 6}^{*} \\
(0.002)\end{array}$ & $-0.01^{4}$ & $\begin{array}{c}-\mathbf{0 . 0 1 4} \\
(0.002)\end{array}$ & $0.00^{5}$ \\
\hline$\Delta$ Inflation $_{i, t}$ & $\phi_{2}$ & $\begin{array}{l}\mathbf{0 . 0 0 5 *} \\
(0.002)\end{array}$ & -0.03 & $\begin{array}{l}\mathbf{0 . 0 0 5 *} \\
(0.002)\end{array}$ & 0.00 \\
\hline$D_{\text {flex.NC }} \Delta r_{i, t}^{U S}$ & $\beta_{3}$ & $\begin{array}{l}\mathbf{0 . 0 1 9 *} \\
(0.005)\end{array}$ & $\begin{array}{l}\mathbf{0 . 0 0 8 *} \\
(0.005)\end{array}$ & $\begin{array}{l}\mathbf{0 . 0 1 8 *} \\
(0.005)\end{array}$ & $\begin{array}{l}\mathbf{0 . 0 0 9 *} \\
(0.005)\end{array}$ \\
\hline$D_{\text {flex.C }} \Delta r_{i, t}^{U S}$ & $\beta_{4}$ & $\begin{array}{l}\mathbf{0 . 0 0 6}^{*} \\
(0.004)\end{array}$ & $\begin{array}{l}-0.003 \\
(0.004)\end{array}$ & $\begin{array}{l}\mathbf{0 . 0 0 6}^{*} \\
(0.004)\end{array}$ & $\begin{array}{l}-0.001 \\
(0.004)\end{array}$ \\
\hline$\Delta V I X_{t}$ & $\delta$ & $\begin{array}{l}\mathbf{0 . 0 6 4 *} \\
(0.006)\end{array}$ & $\begin{array}{l}\mathbf{0 . 0 5 9 *} \\
(0.006) \\
\end{array}$ & $\begin{array}{l}\mathbf{0 . 0 6 6}^{*} \\
(0.006) \\
\end{array}$ & $\begin{array}{l}\mathbf{0 . 0 6 4} \text { * } \\
(0.006) \\
\end{array}$ \\
\hline Adjusted R-squared & & 0.19 & 0.11 & 0.20 & 0.15 \\
\hline No. of Obs. & & 712 & 712 & 712 & 712 \\
\hline
\end{tabular}

4 The estimated coefficient is -0.02 .

5 The estimated coefficient is -0.001 . 
Figure 1a Plot of peripheral countries' policy rate changes vs. US policy rate changes

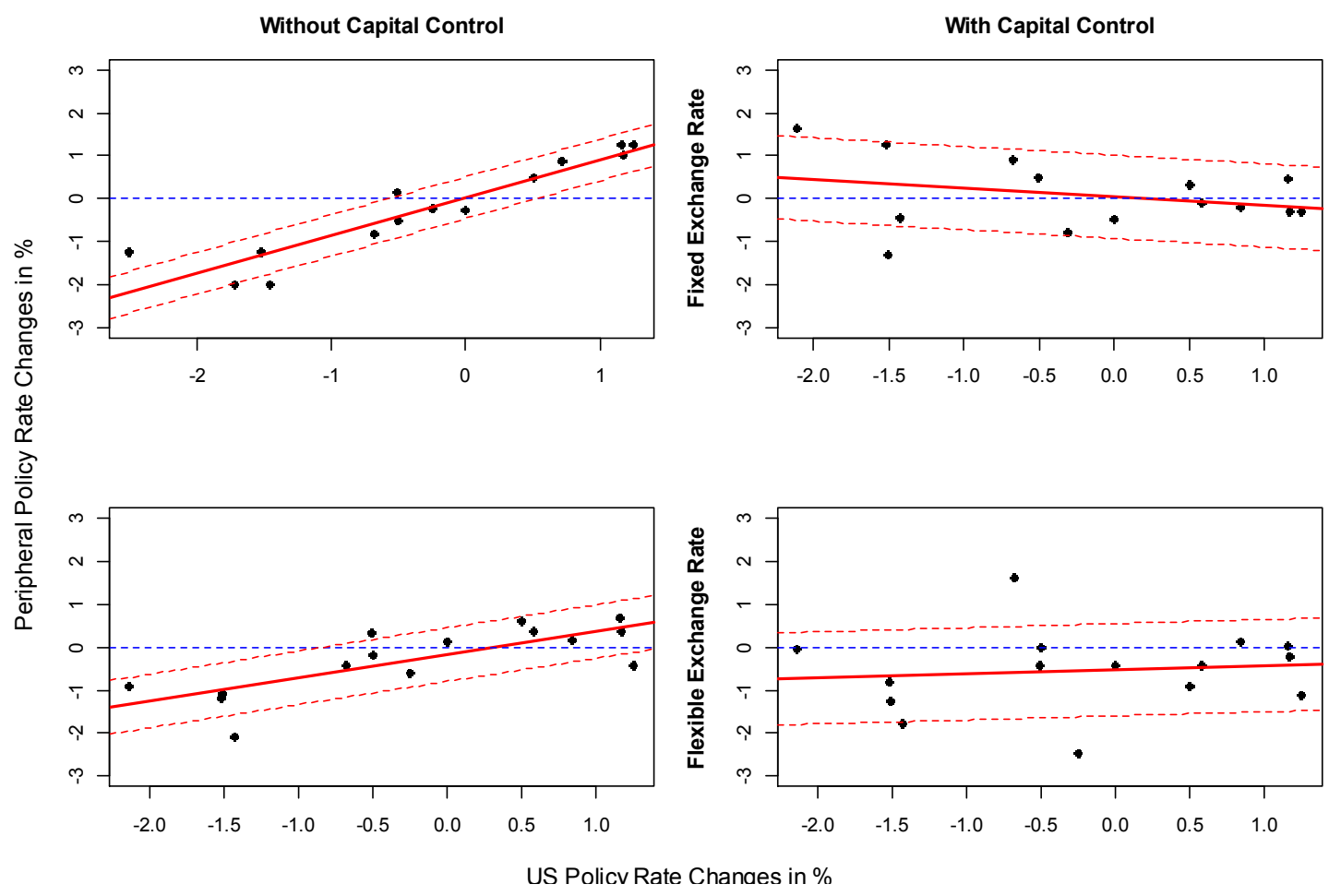

Figure 1b Simulated asymmetric peripheral countries' policy rate responses to US policy rate changes for countries with flexible exchange rate and without capital control based on estimates in column (3) in Table 4

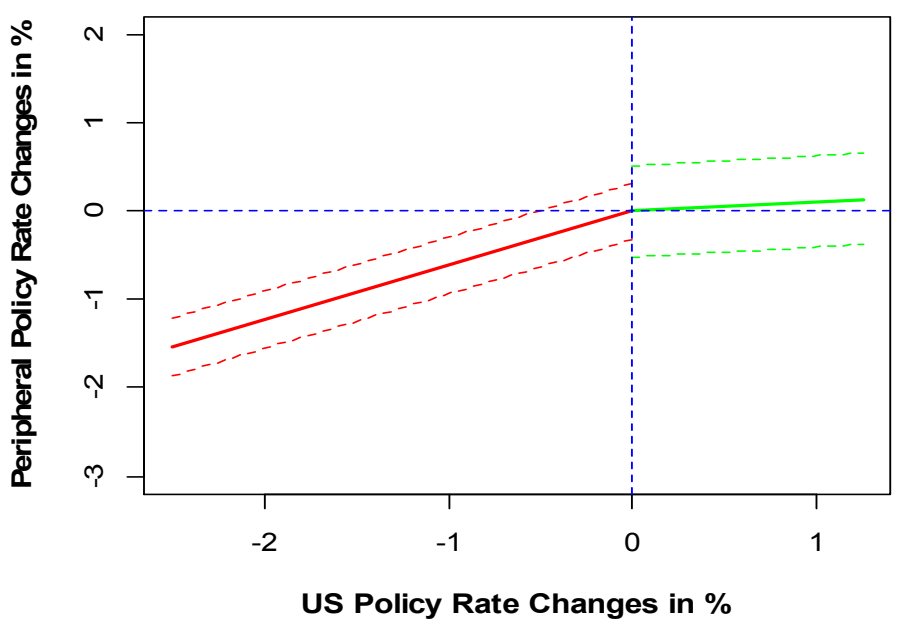




\section{Appendix (online posting only)}

\section{Table A1 Countries included in the analysis and their basic information6}

\begin{tabular}{|c|c|c|c|c|}
\hline Economy & $\begin{array}{l}\text { Emerging } \\
\text { Markets }\end{array}$ & $\begin{array}{l}\text { Euro } \\
\text { Area }^{7}\end{array}$ & $\begin{array}{c}\text { Exchange Rate Structure Classification } \\
\text { indicated in online yearly AREAER } \\
\text { Data }^{8}\end{array}$ & Other Information \\
\hline Argentina & EM & 0 & Managed floating & \\
\hline Australia & No & 0 & Independently floating & \\
\hline Austria & No & 1 & $\begin{array}{l}\text { Exchange arrangement with no separate } \\
\text { legal tender with the euro }\end{array}$ & Joined the euro zone on Jan 1, 1999 \\
\hline Belarus & No & 0 & Crawling band & $\begin{array}{l}\text { While pegged to the Russian ruble } \\
\text { de jure, the National Bank of } \\
\text { Belarus maintains a de facto } \\
\text { crawling band system vis-à-vis the } \\
\text { USD }\end{array}$ \\
\hline Belgium & No & 1 & No separate legal tender with the euro & Joined the euro zone on Jan 1, 1999 \\
\hline Bolivia & No & 0 & Crawling peg & USD is the legal tender \\
\hline Brazil & EM & 0 & Independently floating & \\
\hline Bulgaria & No & 0 & Currency board arrangement & The peg currency is the euro \\
\hline Canada & No & 0 & Independently floating & \\
\hline Chile & EM & 0 & Independently floating & \\
\hline $\begin{array}{l}\text { China, People's } \\
\text { Rep. of }\end{array}$ & $\mathrm{EM}$ & 0 & Conventional pegged arrangement & A benchmark rate for USD \\
\hline
\end{tabular}

6 Effective January 1, 2007, the exchange arrangement of the EMU countries has been reclassified as 'independently floating' from 'exchange

arrangement with no separate legal tender.' The new classification was based on the behavior of the common currency, whereas the previous classification was based on the lack of a separate legal tender.

7 Countries that joined the euro area before 2014 Q2. Lithuania joined on Jan $1{ }^{\text {st }}, 2015$ and is thus not listed as a euro zone country in our dataset.

8 http://www.elibrary.-areaer.imf.org/Areaer/Pages/YearlyReports.aspx, sampled year is 2004. 


\begin{tabular}{|c|c|c|c|c|}
\hline Economy & $\begin{array}{c}\text { Emerging } \\
\text { Markets }\end{array}$ & $\begin{array}{l}\text { Euro } \\
\text { Area }^{7}\end{array}$ & $\begin{array}{c}\text { Exchange Rate Structure Classification } \\
\text { indicated in online yearly AREAER } \\
\text { Data }^{8}\end{array}$ & Other Information \\
\hline Colombia & EM & 0 & Independently floating & \\
\hline Costa Rica & No & 0 & Crawling peg & $\begin{array}{l}\text { Anchoring currency not specified, } \\
\text { but nearly all payments for } \\
\text { exchange transactions are made in } \\
\text { USD }\end{array}$ \\
\hline Croatia & No & 0 & $\begin{array}{l}\text { Managed floating with no pre-determined } \\
\text { path for the exchange rate }\end{array}$ & \\
\hline Cyprus & No & 1 & $\begin{array}{l}\text { Pegged exchange rate within horizontal band } \\
\text { to the euro }\end{array}$ & Joined the euro zone on Jan 1, 2008 \\
\hline Czech Republic & EM & 0 & $\begin{array}{l}\text { Managed floating with no pre-determined } \\
\text { path for the exchange rate }\end{array}$ & $\begin{array}{l}\text { With the euro as the reference } \\
\text { currency }\end{array}$ \\
\hline Denmark & No & 0 & $\begin{array}{l}\text { Pegged exchange rate within horizontal band } \\
\text { to the euro }\end{array}$ & \\
\hline Ecuador & No & 0 & $\begin{array}{l}\text { Exchange arrangement with no separate } \\
\text { legal tender }\end{array}$ & Pegged to the USD \\
\hline Egypt & EM & 0 & $\begin{array}{l}\text { Managed floating with no pre-determined } \\
\text { path for the exchange rate }\end{array}$ & \\
\hline Finland & No & 1 & $\begin{array}{l}\text { Exchange arrangement with no separate } \\
\text { legal tender with the euro }\end{array}$ & Joined the euro zone on Jan 1,1999 \\
\hline France & No & 1 & $\begin{array}{l}\text { Exchange arrangement with no separate } \\
\text { legal tender with the euro }\end{array}$ & Joined the euro zone on Jan 1, 1999 \\
\hline Germany & No & 1 & $\begin{array}{l}\text { Exchange arrangement with no separate } \\
\text { legal tender with the euro }\end{array}$ & Joined the euro zone on Jan 1, 1999 \\
\hline Greece & No & 1 & $\begin{array}{l}\text { Exchange arrangement with no separate } \\
\text { legal tender with the euro }\end{array}$ & Joined the euro zone on Jan 1,2001 \\
\hline Hong Kong, China & $\mathrm{EM}$ & 0 & $\begin{array}{l}\text { Currency board arrangement pegged to the } \\
\text { USD }\end{array}$ & \\
\hline Hungary & EM & 0 & $\begin{array}{l}\text { Pegged exchange rate within horizontal band } \\
\text { to the euro }\end{array}$ & Pegged to the euro \\
\hline Iceland & No & 0 & Independently floating & \\
\hline India & EM & 0 & Managed floating with no pre-determined & With reference to the USD \\
\hline
\end{tabular}




\begin{tabular}{|c|c|c|c|c|}
\hline Economy & $\begin{array}{c}\text { Emerging } \\
\text { Markets }\end{array}$ & $\begin{array}{l}\text { Euro } \\
\text { Area }^{7}\end{array}$ & $\begin{array}{c}\text { Exchange Rate Structure Classification } \\
\text { indicated in online yearly AREAER } \\
\text { Data }^{8}\end{array}$ & Other Information \\
\hline & & & path for the exchange rate & \\
\hline Indonesia & EM & 0 & $\begin{array}{l}\text { Managed floating with no pre-determined } \\
\text { path for the exchange rate }\end{array}$ & \\
\hline Ireland & No & 1 & $\begin{array}{l}\text { Exchange arrangement with no separate } \\
\text { legal tender with the euro }\end{array}$ & Joined the euro zone on Jan 1, 1999 \\
\hline Israel & EM & 0 & Independently floating & \\
\hline Italy & No & 1 & $\begin{array}{l}\text { Exchange arrangement with no separate } \\
\text { legal tender with the euro }\end{array}$ & Joined the euro zone on Jan 1, 1999 \\
\hline Japan & No & 0 & Independently floating & \\
\hline Korea, Republic of & EM & 0 & Independently floating & \\
\hline Latvia & No & 1 & $\begin{array}{l}\text { Conventional pegged arrangement, pegged to } \\
\text { the euro }\end{array}$ & Joined the euro zone on Jan 1, 2014 \\
\hline Lithuania & No & 0 & $\begin{array}{l}\text { Currency board arrangement, pegged to the } \\
\text { euro }\end{array}$ & Joined the euro zone on Jan 1, 2015 \\
\hline Luxembourg & No & 1 & $\begin{array}{l}\text { Exchange arrangement with no separate } \\
\text { legal tender with the euro }\end{array}$ & Joined the euro zone on Jan 1, 1999 \\
\hline Malaysia & EM & 0 & $\begin{array}{l}\text { Conventional pegged arrangement, pegged to } \\
\text { the USD }\end{array}$ & \\
\hline Malta & No & 1 & $\begin{array}{l}\text { Conventional pegged arrangement, pegged to } \\
\text { a basket consisting of USD (10\%), the euro } \\
(70 \%) \text {, and the pound sterling }(20 \%)\end{array}$ & Joined the euro zone on Jan 1, 2008 \\
\hline Mexico & EM & 0 & Independently floating & \\
\hline Netherlands & No & 1 & $\begin{array}{l}\text { Exchange arrangement with no separate } \\
\text { legal tender with the euro }\end{array}$ & Joined the euro zone on Jan 1, 1999 \\
\hline New Zealand & No & 0 & Independently floating & \\
\hline Norway & No & 0 & Independently floating & \\
\hline Pakistan & EM & 0 & $\begin{array}{l}\text { Managed floating with no pre-determined } \\
\text { path for the exchange rate, no anchoring } \\
\text { currency }\end{array}$ & \\
\hline Peru & EM & 0 & $\begin{array}{l}\text { Managed floating with no pre-determined } \\
\text { path for the exchange rate, with the USD as }\end{array}$ & \\
\hline
\end{tabular}




\begin{tabular}{|c|c|c|c|c|}
\hline Economy & $\begin{array}{l}\text { Emerging } \\
\text { Markets }\end{array}$ & $\begin{array}{l}\text { Euro } \\
\text { Area }^{7}\end{array}$ & $\begin{array}{c}\text { Exchange Rate Structure Classification } \\
\text { indicated in online yearly AREAER } \\
\text { Data }^{8}\end{array}$ & Other Information \\
\hline & & & the reference & \\
\hline Philippines & EM & 0 & Independently floating & \\
\hline Poland & EM & 0 & Independently floating & \\
\hline Portugal & No & 1 & $\begin{array}{l}\text { Exchange arrangement with no separate } \\
\text { legal tender with the euro }\end{array}$ & Joined the euro zone on Jan 1, 1999 \\
\hline Romania & No & 0 & $\begin{array}{l}\text { Managed floating with no pre-determined } \\
\text { path for the exchange rate, with the euro as } \\
\text { the reference currency }\end{array}$ & \\
\hline $\begin{array}{l}\text { Russian } \\
\text { Federation }\end{array}$ & EM & 0 & $\begin{array}{l}\text { Managed floating with no pre-determined } \\
\text { path for the exchange rate, with the USD as } \\
\text { the reference currency }\end{array}$ & \\
\hline Serbia, Republic of & No & 0 & $\begin{array}{l}\text { Managed floating with no pre-determined } \\
\text { path for the exchange rate, with the euro as } \\
\text { the reference currency }\end{array}$ & \\
\hline Singapore & EM & 0 & $\begin{array}{l}\text { Managed floating with no pre-determined } \\
\text { path for the exchange rate, with the USD as } \\
\text { the intervention currency }\end{array}$ & \\
\hline Slovak Republic & No & 1 & $\begin{array}{l}\text { Managed floating with no pre-determined } \\
\text { path for the exchange rate }\end{array}$ & Joined the euro zone on Jan 1, 2009 \\
\hline Slovenia & No & 1 & $\begin{array}{l}\text { Pegged exchange rate within horizontal band, } \\
\text { with the euro as the reference currency }\end{array}$ & Joined the euro zone on Jan 1,2007 \\
\hline South Africa & EM & 0 & Independently floating & \\
\hline Spain & No & 1 & $\begin{array}{l}\text { Exchange arrangement with no separate } \\
\text { legal tender with the euro }\end{array}$ & Joined the euro zone on Jan 1, 1999 \\
\hline Sweden & No & 0 & Independently floating & \\
\hline Switzerland & No & 0 & Independently floating & \\
\hline Thailand & EM & 0 & $\begin{array}{l}\text { Managed floating with no pre-determined } \\
\text { path for the exchange rate, with the USD as } \\
\text { the reference currency }\end{array}$ & \\
\hline Turkey & EM & 0 & Independently floating & \\
\hline United Kingdom & No & 0 & Independently floating & \\
\hline
\end{tabular}


Table A2 Short-term policy interest rates and long-term bond yields used for each country

\begin{tabular}{|c|c|c|c|c|}
\hline Country & $\begin{array}{c}\text { Short-term Policy Rate } \\
\text { (All from IFS) }\end{array}$ & $\begin{array}{l}\text { Long-term Bond } \\
\text { (LTB) Yield }\end{array}$ & $\begin{array}{l}\text { Source } \\
\text { of LTB }\end{array}$ & $\begin{array}{c}\text { Coverage } \\
\text { of LTB }\end{array}$ \\
\hline Argentina & $\begin{array}{l}\text { Average rate on peso loans of up to } 15 \\
\text { days between domestic financial } \\
\text { institutions. }\end{array}$ & - & - & - \\
\hline Australia & $\begin{array}{l}\text { Central Bank Policy Rate (End of } \\
\text { Period): Rediscount rate offered by the } \\
\text { RBA to holders of treasury notes. }\end{array}$ & $\begin{array}{l}\text { Government Bond } \\
\text { Yield: } 10 \text { Years }\end{array}$ & CEIC & $\begin{array}{l}\text { Jan } 1970- \\
\text { May } 2015\end{array}$ \\
\hline Austria & See Euro area. & $\begin{array}{l}\text { Government Bond } \\
\text { Yield: Long Term }\end{array}$ & CEIC & $\begin{array}{l}\text { Jan } 1971- \\
\text { Mar } 2015 \\
\end{array}$ \\
\hline Belarus & $\begin{array}{l}\text { Announced rate at which the NBRB } \\
\text { lends to banks. }\end{array}$ & - & - & - \\
\hline Belgium & See Euro area. & $\begin{array}{l}\text { Long-term } \\
\text { Government Bond } \\
\text { Yield }\end{array}$ & Haver & $\begin{array}{l}\text { Jan } 1980- \\
\text { May } 2015\end{array}$ \\
\hline Bolivia & $\begin{array}{l}\text { Rate charged by the CBB on loans in } \\
\text { national currency to financial } \\
\text { corporations collateralized by public } \\
\text { (Treasury or CBB) securities. }\end{array}$ & - & - & - \\
\hline Brazil & $\begin{array}{l}\text { Target rate for overnight interbank } \\
\text { loans collateralized by government } \\
\text { bonds, registered with and traded on } \\
\text { the Sistema Especial de Liquidacao e } \\
\text { Custodia (SELIC). }\end{array}$ & 10-year bond yield & $\begin{array}{l}\text { Investing. } \\
\text { com }\end{array}$ & $\begin{array}{l}\text { Jan } 2007- \\
\text { May } 2015\end{array}$ \\
\hline Bulgaria & $\begin{array}{l}\text { Data refer to Basic Interest Rate } \\
\text { (BIR). BIR is the official reference rate } \\
\text { announced by the Bulgarian National } \\
\text { Bank (BNB) and published in the } \\
\text { State Gazette. }\end{array}$ & $\begin{array}{l}\text { Government Bond } \\
\text { Yield: Long Term }\end{array}$ & CEIC & $\begin{array}{l}\text { July } 1993- \\
\text { Apr } 2015\end{array}$ \\
\hline Canada & $\begin{array}{l}\text { Refers to the overnight money market } \\
\text { (financing) rate, which is a measure or } \\
\text { estimate of the collateralized } \\
\text { overnight rate compiled at the end of } \\
\text { the day by the Bank of Canada } \\
\text { through a survey of major participants } \\
\text { in the overnight market. }\end{array}$ & $\begin{array}{c}\text { Government } \\
\text { Benchmark Bonds } \\
\text { Yield: Month End: } \\
10 \text { Years }\end{array}$ & CEIC & $\begin{array}{l}\text { Jan } 1993- \\
\text { May } 2015\end{array}$ \\
\hline Chile & $\begin{array}{l}\text { Refers to the Monetary Policy Rate } \\
\text { (MPR) which is the target interest } \\
\text { rate for the interbank money market. }\end{array}$ & $\begin{array}{c}\text { Bond Yield: in CLP } \\
10 \text { Years }\end{array}$ & CEIC & $\begin{array}{l}\text { Sep } 2002- \\
\text { May } 2015\end{array}$ \\
\hline $\begin{array}{l}\text { China, } \\
\text { People's } \\
\text { Rep. }\end{array}$ & $\begin{array}{l}\text { Rate charged by the People's Bank of } \\
\text { China on } 20 \text {-day loans to financial } \\
\text { institutions. }\end{array}$ & 10-year bond yield & $\begin{array}{l}\text { Investing. } \\
\text { com }\end{array}$ & $\begin{array}{l}\text { Jan } 1999- \\
\text { May } 2015\end{array}$ \\
\hline Colombia & $\begin{array}{l}\text { Intervention rate determined by the } \\
\text { BR to either increase or decrease } \\
\text { liquidity in the economy. }\end{array}$ & $\begin{array}{c}10 \text { Year Fixed } \\
\text { Treasury Bond Mid } \\
\text { Yield (\% p.a.) } \\
\end{array}$ & Haver & $\begin{array}{l}\text { Jan } 2008- \\
\text { May } 2015\end{array}$ \\
\hline Costa Rica & $\begin{array}{l}\text { Monetary Policy Rate on 30-day } \\
\text { investments. Between Mar 15/2006- } \\
\text { May 28/2008, rate on overnight } \\
\text { deposits on the CBCR's financial } \\
\text { services website. After May } 29,2008 \text {, }\end{array}$ & - & - & - \\
\hline
\end{tabular}




\begin{tabular}{|c|c|c|c|c|}
\hline Country & $\begin{array}{c}\text { Short-term Policy Rate } \\
\text { (All from IFS) }\end{array}$ & $\begin{array}{l}\text { Long-term Bond } \\
\text { (LTB) Yield }\end{array}$ & $\begin{array}{l}\text { Source } \\
\text { of LTB }\end{array}$ & $\begin{array}{l}\text { Coverage } \\
\text { of LTB }\end{array}$ \\
\hline & $\begin{array}{l}\text { rate charged by the CBCR on one-day } \\
\text { loans in the Interbank Money Market } \\
\text { or Integrated Liquidity Market. } \\
\text { Beginning June } 3,2011 \text {, target rate } \\
\text { used by the CBCR as a reference for } \\
\text { one-day operations within a band in } \\
\text { the Integrated Liquidity Market. }\end{array}$ & & & \\
\hline Croatia & $\begin{array}{l}\text { Basic rate at which the CNB lends to } \\
\text { commercial banks. }\end{array}$ & $\begin{array}{c}\text { Long-term } \\
\text { Government Bond } \\
\text { Yield: Average (\%) }\end{array}$ & Haver & $\begin{array}{l}\text { Dec } 2005- \\
\text { May } 2015\end{array}$ \\
\hline Cyprus & $\begin{array}{l}\text { Rate charged by the CBC for the } \\
\text { discount of treasury bills. }\end{array}$ & $\begin{array}{l}\text { Government Bond } \\
\text { Yield: Long Term }\end{array}$ & CEIC & $\begin{array}{l}\text { Nov } 1997- \\
\text { Apr } 2015 \\
\end{array}$ \\
\hline $\begin{array}{l}\text { Czech } \\
\text { Republic }\end{array}$ & $\begin{array}{l}\text { Repo rate (14-day) between the Czech } \\
\text { National Bank and commercial banks. }\end{array}$ & $\begin{array}{c}\text { Long-term } \\
\text { Government Bond } \\
\text { Yield: Average (\%) }\end{array}$ & Haver & $\begin{array}{c}\text { Apr } 2000- \\
\text { May } 2015\end{array}$ \\
\hline Denmark & $\begin{array}{l}\text { Denmark National bank's shor term } \\
\text { interest rate. }\end{array}$ & $\begin{array}{l}\text { Government Bond } \\
\text { Yield: Long Term }\end{array}$ & CEIC & $\begin{array}{l}\text { Jan } 1970- \\
\text { Apr } 2015 \\
\end{array}$ \\
\hline Ecuador & $\begin{array}{l}\text { Legal rate charged by the CBE to } \\
\text { discount eligible commercial papers } \\
\text { offered by commercial banks }\end{array}$ & - & - & - \\
\hline Egypt & $\begin{array}{l}\text { The rate at which the CBE discounts } \\
\text { eligible commercial papers to } \\
\text { commercial banks. }\end{array}$ & - & - & - \\
\hline Euro area & $\begin{array}{l}\text { Eurosystem Main Refinancing } \\
\text { Operations Rate, which is the rate for } \\
\text { the main open-market operations in } \\
\text { the form of regular liquidity-providing } \\
\text { reverse transactions with a frequency } \\
\text { and maturity of one week. Reverse } \\
\text { transactions refer to repurchase } \\
\text { agreements or collateralized loans. }\end{array}$ & - & - & - \\
\hline Finland & See Euro area. & $\begin{array}{c}\text { Benchmark } \\
\text { Government Bond } \\
\text { Yield: Average: } 10 \\
\text { Years } \\
\end{array}$ & CEIC & $\begin{array}{l}\text { Jan } 1992- \\
\text { May } 2015\end{array}$ \\
\hline France & See Euro area. & $\begin{array}{l}\text { Government Bond } \\
\text { Yield: Monthly } \\
\text { Average: } 10 \text { Years } \\
\end{array}$ & CEIC & $\begin{array}{c}\text { Jan } 1999- \\
\text { May } 2015\end{array}$ \\
\hline Germany & See Euro area. & $\begin{array}{c}\text { Long-term } \\
\text { Government Bond } \\
\text { Yield: Average (\%) } \\
\end{array}$ & Haver & $\begin{array}{l}\text { Jan } 1980- \\
\text { May } 2015\end{array}$ \\
\hline Greece & See Euro area. & $\begin{array}{l}\text { Government Bond } \\
\text { Yield: Average: } 10 \\
\text { Years } \\
\end{array}$ & CEIC & $\begin{array}{l}\text { Jan } 1993- \\
\text { May } 2015\end{array}$ \\
\hline $\begin{array}{l}\text { Hong Kong, } \\
\text { China }\end{array}$ & $\begin{array}{l}\text { Exchange Fund's overnight liquidity } \\
\text { adjustment facility offer rate. }\end{array}$ & - & - & - \\
\hline Hungary & $\begin{array}{l}\text { Basic rate at which NBH offers loans } \\
\text { with maturity of more than one year to } \\
\text { other MFIs. }\end{array}$ & $\begin{array}{l}\text { Long-term } \\
\text { Government Bond } \\
\text { Yield: Average (\%) }\end{array}$ & Haver & $\begin{array}{c}\text { Jan } 2001- \\
\text { May } 2015\end{array}$ \\
\hline Iceland & Rate on overdrafts of other depository & Government Bond & Haver & Jan $1992-$ \\
\hline
\end{tabular}




\begin{tabular}{|c|c|c|c|c|}
\hline Country & $\begin{array}{c}\text { Short-term Policy Rate } \\
\text { (All from IFS) }\end{array}$ & $\begin{array}{l}\text { Long-term Bond } \\
\text { (LTB) Yield }\end{array}$ & $\begin{array}{l}\text { Source } \\
\text { of LTB }\end{array}$ & $\begin{array}{l}\text { Coverage } \\
\text { of LTB }\end{array}$ \\
\hline & corporations. & $\begin{array}{l}\text { Yield: } 10 \text { years (\% } \\
\text { per annum) }\end{array}$ & & May 2015 \\
\hline India & $\begin{array}{l}\text { Standard rate at which the Reserve } \\
\text { Bank makes advances to scheduled } \\
\text { banks against commercial paper and } \\
\text { government securities. }\end{array}$ & 10-year bond yield & $\begin{array}{l}\text { Investing. } \\
\text { com }\end{array}$ & $\begin{array}{l}\text { May } 1998- \\
\text { May } 2015\end{array}$ \\
\hline Indonesia & $\begin{array}{l}\text { Bank Indonesia rate, the policy rate } \\
\text { reflecting the monetary policy stance } \\
\text { announced to the public. }\end{array}$ & 10-year bond yield & $\begin{array}{l}\text { Investing. } \\
\text { com }\end{array}$ & $\begin{array}{l}\text { Jan } 2006- \\
\text { May } 2015\end{array}$ \\
\hline Ireland & See Euro area. & $\begin{array}{c}\text { Government Bonds } \\
\text { Yield: } 10 \text { Years to } \\
\text { Maturity } \\
\end{array}$ & CEIC & $\begin{array}{c}\text { Dec } 1992- \\
\text { Apr } 2015\end{array}$ \\
\hline Israel & $\begin{array}{l}\text { Rate on monetary loans offered by } \\
\text { tender by the Bank of Israel to } \\
\text { commercial banks. }\end{array}$ & $\begin{array}{c}\text { Yield on 10-Year } \\
\text { Indexed Government } \\
\text { Bonds (AVG, \% p.a.) }\end{array}$ & Haver & $\begin{array}{l}\text { Jan } 1992- \\
\text { Dec } 2014\end{array}$ \\
\hline Italy & See Euro area. & $\begin{array}{c}\text { Government } \\
\text { Treasury Bonds } \\
\text { Yield: } 10 \text { Year } \\
\end{array}$ & CEIC & $\begin{array}{c}\text { Mar } 1991- \\
\text { May } 2015\end{array}$ \\
\hline Japan & $\begin{array}{l}\text { Rate at which the BOJ discounts } \\
\text { eligible commercial bills and loans } \\
\text { secured by government bonds, } \\
\text { specially designed securities, and } \\
\text { eligible commercial bills. }\end{array}$ & $\begin{array}{l}\text { 10-Year Benchmark } \\
\text { Government Bond } \\
\text { Yield (AVG, \% p.a.) }\end{array}$ & Haver & $\begin{array}{l}\text { July } 1986- \\
\text { May } 2015\end{array}$ \\
\hline $\begin{array}{l}\text { Korea, } \\
\text { Republic of }\end{array}$ & $\begin{array}{l}\text { The Base Rate is the reference rate set } \\
\text { by the Monetary Policy Committee } \\
\text { and applied to transactions between } \\
\text { the BOK and financial institutions. }\end{array}$ & $\begin{array}{l}\text { Government Bond } \\
\text { Yield: Long Term }\end{array}$ & CEIC & $\begin{array}{l}\text { May } 1973- \\
\text { Mar } 2015\end{array}$ \\
\hline Latvia & $\begin{array}{l}\text { Beginning in January 2014, Euro Area } \\
\text { policy rates became applicable, and } \\
\text { national policy rates were } \\
\text { discontinued. }\end{array}$ & $\begin{array}{c}\text { Long-term } \\
\text { Government Bond } \\
\text { Yield: Average (\%) }\end{array}$ & Haver & $\begin{array}{l}\text { Jan } 2001- \\
\text { May } 2015\end{array}$ \\
\hline Lithuania & $\begin{array}{l}\text { Repurchase Agreement Rate (End of } \\
\text { Period): Bank of Lithuania rate on } \\
\text { overnight repurchase agreements. }\end{array}$ & $\begin{array}{c}\text { Long-term } \\
\text { Government Bond } \\
\text { Yield: Average (\%) }\end{array}$ & Haver & $\begin{array}{l}\text { Jan } 2001- \\
\text { May } 2015\end{array}$ \\
\hline $\begin{array}{l}\text { Luxembour } \\
\mathrm{g}\end{array}$ & See Euro area. & $\begin{array}{l}\text { Government Bond } \\
\text { Yield: Long Term }\end{array}$ & CEIC & $\begin{array}{l}\text { Jan } 1970- \\
\text { Mar } 2015 \\
\end{array}$ \\
\hline Malaysia & $\begin{array}{l}\text { The overnight policy rate, set by BNM } \\
\text { for monetary policy direction. }\end{array}$ & - & - & - \\
\hline Malta & $\begin{array}{l}\text { Rate at which the CBM lends to credit } \\
\text { institutions. }\end{array}$ & $\begin{array}{l}\text { Government Bond } \\
\text { Rate: Long Term: } 10 \\
\text { Years } \\
\end{array}$ & CEIC & $\begin{array}{l}\text { Jan } 1999- \\
\text { Apr } 2015\end{array}$ \\
\hline Mexico & Refers to the target rate. & $\begin{array}{l}\text { Government Bond } \\
\text { Yield: Long Term }\end{array}$ & CEIC & $\begin{array}{l}\text { Jan } 1995- \\
\text { May } 2015 \\
\end{array}$ \\
\hline $\begin{array}{l}\text { Netherland } \\
\mathrm{s}\end{array}$ & See Euro area. & $\begin{array}{l}\text { Government Bond } \\
\text { Yield: Long Term }\end{array}$ & CEIC & $\begin{array}{l}\text { Jan } 1970- \\
\text { Apr } 2015 \\
\end{array}$ \\
\hline $\begin{array}{l}\text { New } \\
\text { Zealand }\end{array}$ & $\begin{array}{l}\text { Official Cash Rate (OCR) around } \\
\text { which the Reserve Bank transacts } \\
\text { with the market. Reviewed eight } \\
\text { times a year (every six and a half } \\
\text { weeks). }\end{array}$ & $\begin{array}{l}\text { Government Bond } \\
\text { Yield: } 10 \text { Years }\end{array}$ & CEIC & $\begin{array}{c}\text { Jan } 1985- \\
\text { May } 2015\end{array}$ \\
\hline
\end{tabular}




\begin{tabular}{|c|c|c|c|c|}
\hline Country & $\begin{array}{c}\text { Short-term Policy Rate } \\
\text { (All from IFS) }\end{array}$ & $\begin{array}{l}\text { Long-term Bond } \\
\text { (LTB) Yield }\end{array}$ & $\begin{array}{l}\text { Source } \\
\text { of LTB }\end{array}$ & $\begin{array}{l}\text { Coverage } \\
\text { of LTB }\end{array}$ \\
\hline Norway & $\begin{array}{l}\text { Marginal lending rate of the Bank of } \\
\text { Norway. }\end{array}$ & $\begin{array}{l}\text { Government Bonds } \\
\text { Yield: Monthly Avg: } \\
10 \text { Years } \\
\end{array}$ & CEIC & $\begin{array}{c}\text { Jan } 1985- \\
\text { May } 2015\end{array}$ \\
\hline Pakistan & $\begin{array}{l}\text { The State Bank of Pakistan rate on its } \\
\text { repurchase facility. }\end{array}$ & $\begin{array}{c}\text { Investment Bonds: } \\
\text { Wtd Avg Yield: } \\
\text { 10-years } \\
\end{array}$ & Haver & $\begin{array}{l}\text { Dec } 2000- \\
\text { May } 2015\end{array}$ \\
\hline Peru & $\begin{array}{l}\text { Reference rate determined by CRBP to } \\
\text { establish a benchmark interest rate } \\
\text { for interbank transactions, impacting } \\
\text { operations of the financial institutions } \\
\text { with the public. }\end{array}$ & - & - & - \\
\hline Philippines & $\begin{array}{l}\text { Rediscount rate for loans for } \\
\text { traditional exports, which account for } \\
\text { a large part of total rediscount credits. }\end{array}$ & 10-year bond yield & $\begin{array}{l}\text { Investing. } \\
\text { com }\end{array}$ & $\begin{array}{l}\text { Jul } 2000- \\
\text { May } 2015\end{array}$ \\
\hline Poland & $\begin{array}{l}\text { Repo Rate (End of Period): Reference } \\
\text { rate (minimum money market } \\
\text { intervention rate) quoted by the NBP } \\
\text { on } 28 \text {-day open market operations } \\
\text { (reverse repo rate). }\end{array}$ & $\begin{array}{l}\text { Long-term } \\
\text { Government Bond } \\
\text { Yield: Average (\%) }\end{array}$ & Haver & $\begin{array}{l}\text { Jan } 2001- \\
\text { May } 2015\end{array}$ \\
\hline Portugal & See Euro area. & $\begin{array}{l}\text { Treasury Bond } \\
\text { Yield: } 10 \text { Years }\end{array}$ & CEIC & $\begin{array}{l}\text { Jul } 1993- \\
\text { Apr } 2015 \\
\end{array}$ \\
\hline Romania & $\begin{array}{l}\text { Monetary policy rate is the rate on } \\
\text { one-week deposit-taking operations } \\
\text { starting on May } 7,2008 \text {, the rate on } \\
\text { two-week deposit-taking operations } \\
\text { from August } 1,2007 \text { until May } 6,2008 \\
\text { and the rate on one-month } \\
\text { deposit-taking operations before } \\
\text { August } 1,2007 \text {. }\end{array}$ & $\begin{array}{l}\text { Government Bond } \\
\text { Yield: Long Term }\end{array}$ & CEIC & $\begin{array}{c}\text { Apr } 2005- \\
\text { Apr } 2015\end{array}$ \\
\hline $\begin{array}{l}\text { Russian } \\
\text { Federation }\end{array}$ & $\begin{array}{l}\text { Minimum bid rate for one-day } \\
\text { repurchase agreements auction of } \\
\text { CBR with credit institutions. }\end{array}$ & $\begin{array}{l}\text { Government Bonds } \\
\text { Yield: Period End: } \\
\text { GKO-OFZ: } \\
\text { Redemption Term } 10 \\
\text { Years } \\
\end{array}$ & CEIC & $\begin{array}{l}\text { Jan } 2003- \\
\text { May } 2015\end{array}$ \\
\hline Serbia & $\begin{array}{l}\text { Monthly average rate on the NBS bills } \\
\text { of all maturities weighted by volume. }\end{array}$ & - & - & - \\
\hline Singapore & $\begin{array}{l}\text { Rate charged by the MAS on overnight } \\
\text { repurchase agreements using } \\
\text { government securities. }\end{array}$ & $\begin{array}{l}\text { Average Buying } \\
\text { Rates of Govt } \\
\text { Securities Dealers } \\
\text { 10-Year Bond Yield }\end{array}$ & $\begin{array}{c}\text { Singapore } \\
\text { Governme } \\
\text { nt } \\
\text { Securities } \\
\text { and } \\
\text { Monetary } \\
\text { Authority } \\
\text { of } \\
\text { Singapore }\end{array}$ & $\begin{array}{l}\text { Jun } 1998- \\
\text { May } 2015\end{array}$ \\
\hline $\begin{array}{l}\text { Slovak } \\
\text { Republic }\end{array}$ & $\begin{array}{l}\text { Beginning January 2009, Euro Area } \\
\text { policy rates. For periods prior to } \\
\text { January 2009, Central Bank Policy } \\
\text { Rate (End of Period): National Bank of } \\
\text { Slovakia's main policy rate. Rate on }\end{array}$ & $\begin{array}{l}\text { 10-year Government } \\
\text { Bond Yield (\% per } \\
\text { annum) }\end{array}$ & Haver & $\begin{array}{l}\text { Sep } 2000- \\
\text { Mar } 2015\end{array}$ \\
\hline
\end{tabular}




\begin{tabular}{|c|c|c|c|c|}
\hline Country & $\begin{array}{c}\text { Short-term Policy Rate } \\
\text { (All from IFS) }\end{array}$ & $\begin{array}{l}\text { Long-term Bond } \\
\text { (LTB) Yield }\end{array}$ & $\begin{array}{l}\text { Source } \\
\text { of LTB }\end{array}$ & $\begin{array}{c}\text { Coverage } \\
\text { of LTB }\end{array}$ \\
\hline & $\begin{array}{l}\text { two-week repurchase agreements with } \\
\text { commercial banks. }\end{array}$ & & & \\
\hline Slovenia & See Euro area. & $\begin{array}{l}\text { Government Bond } \\
\text { Yield: Long Term }\end{array}$ & CEIC & $\begin{array}{l}\text { Mar } 2002- \\
\text { Apr } 2015 \\
\end{array}$ \\
\hline $\begin{array}{l}\text { South } \\
\text { Africa }\end{array}$ & $\begin{array}{l}\text { Rate determined by the SARB on } \\
\text { repurchase agreements in national } \\
\text { currency between the SARB and } \\
\text { private sector banks. The repo rate } \\
\text { was introduced on March } 9,1998 \text {. }\end{array}$ & $\begin{array}{l}\text { Government Bond } \\
\text { Yield: Monthly } \\
\text { Average: } 10 \text { Years } \\
\text { and Over }\end{array}$ & CEIC & $\begin{array}{c}\text { Jan } 1970- \\
\text { Apr } 2015\end{array}$ \\
\hline Spain & See Euro area. & $\begin{array}{c}\text { Long-term } \\
\text { Government Bond } \\
\text { Yield: Average (\%) }\end{array}$ & Haver & $\begin{array}{l}\text { Jan } 1980- \\
\text { May } 2015\end{array}$ \\
\hline Sweden & $\begin{array}{l}\text { Data refer to the reference rate set by } \\
\text { the Riksbank at six-monthly intervals, } \\
\text { and is based on the repurchase } \\
\text { agreement rate applying at the end of } \\
\text { the previous six-month period, } \\
\text { rounded up to the nearest whole or } \\
\text { half percentage point. }\end{array}$ & $\begin{array}{l}\text { Government Bond } \\
\text { Yield: Riksbank: } \\
\text { Average: } 10 \text { Years }\end{array}$ & CEIC & $\begin{array}{l}\text { Jan } 1987- \\
\text { May } 2015\end{array}$ \\
\hline Switzerland & $\begin{array}{l}\text { Data refer to official discount rates. } \\
\text { Beginning in January } 2000 \text {, data refer } \\
\text { to the upper limit of the target range } \\
\text { for three-month Swiss franc interbank } \\
\text { market for unsecured loans set by the } \\
\text { SNB. }\end{array}$ & Bond Yield: 10 Years & CEIC & $\begin{array}{l}\text { Jan } 1988- \\
\text { May } 2015\end{array}$ \\
\hline Thailand & $\begin{array}{l}\text { Policy rate is the rate announced by } \\
\text { the Monetary Policy Committee in } \\
\text { conducting monetary policy under the } \\
\text { inflation-targeting framework. }\end{array}$ & $\begin{array}{c}\text { Treasury Bill \& } \\
\text { Government Bond } \\
\text { Yield: Average: BOT: } \\
\text { 10 Year }\end{array}$ & CEIC & $\begin{array}{l}\text { Jan } 2005- \\
\text { May } 2015\end{array}$ \\
\hline Turkey & $\begin{array}{l}\text { Interbank rate at which funds can be } \\
\text { lent and borrowed for one day } \\
\text { (overnight). The CBRT uses this base } \\
\text { rate for monetary policy purposes. }\end{array}$ & 10-year bond yield & $\begin{array}{l}\text { Investing. } \\
\text { com }\end{array}$ & $\begin{array}{l}\text { Feb } 2010- \\
\text { May } 2015\end{array}$ \\
\hline $\begin{array}{l}\text { United } \\
\text { Kingdom }\end{array}$ & $\begin{array}{l}\text { Refers to the official bank rate, also } \\
\text { called the Bank of England base rate } \\
\text { or BOEBR, which is the rate that the } \\
\text { Bank of England charges banks on } \\
\text { secured overnight loans. It is the } \\
\text { British government's key interest rate } \\
\text { for enacting monetary policy. }\end{array}$ & $\begin{array}{l}\text { Government Bond } \\
\text { Yield: Zero Coupon: } \\
\text { Monthly Avg: } 10 \\
\text { Years }\end{array}$ & CEIC & $\begin{array}{l}\text { Jan } 1982- \\
\text { May } 2015\end{array}$ \\
\hline $\begin{array}{l}\text { United } \\
\text { States }\end{array}$ & $\begin{array}{l}\text { Refers to the federal funds rate, which } \\
\text { is the rate at which private depository } \\
\text { institutions (mostly banks) lend } \\
\text { balances (federal funds) at the Federal } \\
\text { Reserve to other depository } \\
\text { institutions, usually overnight. }\end{array}$ & $\begin{array}{l}\text { Government Bond } \\
\text { Yield: Long Term }\end{array}$ & CEIC & $\begin{array}{l}\text { Jan } 1970- \\
\text { Apr } 2015\end{array}$ \\
\hline
\end{tabular}


Table A3 Exchange rate arrangements 1990-2010 from Ilzetzki et al. (2010)

\begin{tabular}{|c|c|c|c|}
\hline Country & Date & $\begin{array}{l}\text { Classification: } \\
\text { Primary/Secondary/Tertiary }\end{array}$ & Comments \\
\hline \multirow[t]{9}{*}{ Argentina } & April 1986-December 20, 1990 & $\begin{array}{l}\text { Freely falling/Freely floating/Dual } \\
\text { Market/Multiple rates }\end{array}$ & $\begin{array}{l}\text { The Austral Plan's second phase was a } \\
\text { crawling peg which lasted until September } \\
1986 \text { but by then, there was a dual market. } \\
\text { For May 1989-March } 1990 \text { the regime is a } \\
\text { "hyperfloat." }\end{array}$ \\
\hline & $\begin{array}{l}\text { December 20, 1990-January 29, } \\
1991\end{array}$ & Freely falling/Freely floating & \\
\hline & January 29, 1991-March 1991 & Freely falling/Freely floating & $\begin{array}{l}\text { A "Target zone"-broad band is } \\
\text { introduced. }\end{array}$ \\
\hline & April 1991-February 1992 & $\begin{array}{l}\text { Currency Board/Peg to the US } \\
\text { dollar/Freely falling }\end{array}$ & $\begin{array}{l}\text { The Convertibility Plan, no adjustments to } \\
\text { central parity. }\end{array}$ \\
\hline & March 1992-December 1, 2001 & Currency Board/Peg to the US dollar & \\
\hline & December 1, 2001-June 2002 & Freely falling/De facto Dual Market & $\begin{array}{l}\text { Capital controls are introduced. There are } \\
\text { multiple exchange rates through most of } \\
2001 \text {. }\end{array}$ \\
\hline & February 2003-January 2007 & $\begin{array}{l}\text { De facto crawling band around the } \\
\text { US dollar }\end{array}$ & $\begin{array}{l}+/-5 \% \text { band. Workers from INDEC, the } \\
\text { state statistical agency, released their own } \\
\text { unofficial inflation estimates that far } \\
\text { outstripped the government's estimate of } \\
\text { an } 8.5 \% \text { y-o-y CPI increase for } 2007 \text {. They } \\
\text { reported that } 2007 \text { inflation had in fact } \\
\text { been between } 22.3 \% \text { and } 26.2 \% \text {. }\end{array}$ \\
\hline & February 2007-June 2009 & $\begin{array}{l}\text { De facto crawling band around the } \\
\text { US dollar }\end{array}$ & $+/-2 \%$ band. \\
\hline & July 2009-December 2010 & $\begin{array}{l}\text { De facto crawling peg to the US } \\
\text { dollar }\end{array}$ & \\
\hline Australia & $\begin{array}{l}\text { December 12, 1983-December } \\
2010\end{array}$ & Freely floating & \\
\hline \multirow[t]{2}{*}{ Austria } & & De facto peg to the DM & $\begin{array}{l}\text { March } 1991 \text { registers as a currency crash } \\
\text { versus the US dollar-none versus the } \\
\text { DM. }\end{array}$ \\
\hline & January 1, 1999-December 2010 & Currency union & Euro. \\
\hline
\end{tabular}




\begin{tabular}{|c|c|c|c|}
\hline Country & Date & $\begin{array}{l}\text { Classification: } \\
\text { Primary/Secondary/Tertiary }\end{array}$ & Comments \\
\hline \multirow[t]{6}{*}{ Belarus } & August 25, 1991-February 3, 1997 & $\begin{array}{l}\text { Freely falling/Freely floating/Multiple } \\
\text { rates }\end{array}$ & There is no price data before this date. \\
\hline & February 3, 1997-March 31, 1998 & Freely falling/Freely floating & \\
\hline & March 31, 1998-December 2002 & Freely falling/Freely floating & There are multiple rates. \\
\hline & 2003 & $\begin{array}{l}\text { De facto crawling band around the } \\
\text { US dollar }\end{array}$ & $\begin{array}{l}+/-2 \% \text { band. Officially a crawling band } \\
\text { around a basket of currencies. }\end{array}$ \\
\hline & January 2003-March 2010 & De facto peg to the US dollar & $\begin{array}{l}\text { Officially a crawling band around a basket } \\
\text { of currencies. Official band widened to }+/- \\
15 \% \text { in } 2008 \text {. }\end{array}$ \\
\hline & April 2010-December 2010 & $\begin{array}{l}\text { De facto crawling band around the } \\
\text { US dollar }\end{array}$ & $+/-5 \%$ band \\
\hline \multirow[t]{3}{*}{ Belgium } & November 1971-March 5, 1990 & De facto peg to the DM/Dual Market & \\
\hline & March 5, 1990-December 31, 1998 & De facto peg to the DM & \\
\hline & January 1, 1999-December 2010 & Currency union & Euro. \\
\hline \multirow[t]{2}{*}{ Bolivia } & January 1990-October 2008 & $\begin{array}{l}\text { De facto crawling peg to the US } \\
\text { dollar/Multiple rates/parallel market }\end{array}$ & Parallel market premium is trivial. \\
\hline & November 2008-December 2010 & De facto peg to the US dollar & \\
\hline \multirow[t]{6}{*}{ Brazil } & April 1989-July 1, 1994 & $\begin{array}{l}\text { Freely falling/Freely floating/Multiple } \\
\text { rates }\end{array}$ & $\begin{array}{l}\text { On December } 1989 \text {, the parallel market } \\
\text { premium rises to } 235 \% \text {. December } 1989- \\
\text { March } 1990 \text { regime is a "hyperfloat." }\end{array}$ \\
\hline & July 1, 1994-May 1995 & Pre-announced crawling band to the & The Real Plan has a narrow band width. \\
\hline & & US dollar/Freely falling/Dual Market & $\begin{array}{l}\text { The real replaces the cruzado. There is a } \\
\text { dual market but parallel premium during } \\
\text { this period is trivial. }\end{array}$ \\
\hline & June 1995-January 18, 1999 & $\begin{array}{l}\text { Pre-announced crawling band to the } \\
\text { US dollar/Dual Market }\end{array}$ & \\
\hline & February 1, 1999-August 1999 & Freely falling/Managed floating & $\begin{array}{l}\text { On January } 18,1999 \text {, the two rates were } \\
\text { unified. }\end{array}$ \\
\hline & September 1999-December 2010 & Managed floating & \\
\hline \multirow[t]{2}{*}{ Bulgaria } & May 2, 1990-December 1993 & Freely falling/Freely floating & There is no price data before this date. \\
\hline & January 1994-January 1, 1997 & Freely falling/Managed floating & \\
\hline
\end{tabular}




\begin{tabular}{|c|c|c|c|}
\hline Country & Date & $\begin{array}{l}\text { Classification: } \\
\text { Primary/Secondary/Tertiary }\end{array}$ & Comments \\
\hline & January 1, 1997-January 1998 & $\begin{array}{l}\text { Peg to the DM/Currency board/Freely } \\
\text { falling }\end{array}$ & \\
\hline & January 1998-January 1, 1999 & Currency board/Peg to the DM & \\
\hline & January 1, 1999-December, 2010 & Currency board/Peg to the euro & \\
\hline \multirow[t]{2}{*}{ Canada } & May 31, 1970-May 2002 & $\begin{array}{l}\text { De facto moving band around the US } \\
\text { dollar }\end{array}$ & $+/-2 \%$ band. \\
\hline & June 2002-December 2010 & $\begin{array}{l}\text { De facto moving band around the US } \\
\text { dollar/Managed floating }\end{array}$ & $+/-5 \%$ band. \\
\hline \multirow[t]{7}{*}{ Chile } & June 1, 1989-January 22, 1992 & $\begin{array}{l}\text { Pre-announced crawling band around } \\
\text { the US dollar/Dual Market }\end{array}$ & $\begin{array}{l}\text { PPP rule. Official pre-announced }+/-5 \% \\
\text { band. }\end{array}$ \\
\hline & January 22, 1992-January 20, 1997 & $\begin{array}{l}\text { De facto crawling band around the } \\
\text { US dollar/Dual Market }\end{array}$ & $\begin{array}{l}\text { PPP rule. }+/-5 \% \text { band. Official } \\
\text { pre-announced crawling }+/-10 \% \text { band to } \\
\text { the US dollar. Parallel premium declines to } \\
\text { below } 15 \% \text { and into single digits. }\end{array}$ \\
\hline & January 20, 1997-June 25, 1998 & $\begin{array}{l}\text { De facto crawling band to the US } \\
\text { dollar/Dual Market }\end{array}$ & $\begin{array}{l}\text { Official pre-announced }+/-12.5 \% \text { crawling } \\
\text { band to the US dollar. De facto band is }+/- \\
5 \% \text { for the official rate. }\end{array}$ \\
\hline & June 25, 1998-September 16, 1998 & $\begin{array}{l}\text { Pre-announced crawling band to the } \\
\text { US dollar/Dual Market }\end{array}$ & $\begin{array}{l}+-2.75 \% \text { band. Rates are virtually the } \\
\text { same in official and informal markets. }\end{array}$ \\
\hline & $\begin{array}{l}\text { September 16, 1998-December 22, } \\
1998\end{array}$ & $\begin{array}{l}\text { Pre-announced crawling band to the } \\
\text { US dollar/Dual Market }\end{array}$ & $+/-3.5 \%$ band \\
\hline & $\begin{array}{l}\text { December 22, 1998-September 2, } \\
1999\end{array}$ & $\begin{array}{l}\text { Pre-announced crawling band to the } \\
\text { US dollar/Dual Market }\end{array}$ & $+/-8 \%$ band. \\
\hline & September 2, 1999-December 2010 & De facto band around the US dollar & Markets are unified. $+/-5 \%$ band. \\
\hline $\begin{array}{l}\text { Hong Kong, } \\
\text { China }\end{array}$ & October 17, 1983-December 2010 & Currency board/Peg to the US dollar & \\
\hline \multirow{4}{*}{$\begin{array}{l}\text { China, People's } \\
\text { Rep. of }\end{array}$} & March 1981-July 1992 & Managed floating/Multiple rates & \\
\hline & August 1992-January 1, 1994 & $\begin{array}{l}\text { De facto crawling band around the } \\
\text { US dollar/Multiple rates }\end{array}$ & $\begin{array}{l}+/-2 \% \text { band. Premium peaks at } 124 \% \text { on } \\
\text { June } 1991 .\end{array}$ \\
\hline & January 1, 1994-July 2005 & De facto peg to the US dollar & $\begin{array}{l}\text { Unification of markets. There is a parallel } \\
\text { market where the premium is in single } \\
\text { digits. }\end{array}$ \\
\hline & August 2005-September 2009 & De facto moving band to the US & $+/-2 \%$ band. \\
\hline
\end{tabular}




\begin{tabular}{|c|c|c|c|}
\hline Country & Date & $\begin{array}{l}\text { Classification: } \\
\text { Primary/Secondary/Tertiary }\end{array}$ & Comments \\
\hline & & dollar & \\
\hline & October 2009-December 2010 & De facto peg to the US dollar & \\
\hline \multirow[t]{4}{*}{ Colombia } & December 1984-January 24, 1994 & $\begin{array}{l}\text { De facto band around the US } \\
\text { dollar/Multiple rates }\end{array}$ & $+/-5 \%$ band. \\
\hline & January 24, 1994-June 28, 1999 & $\begin{array}{l}\text { De facto crawling band around the } \\
\text { US dollar }\end{array}$ & $\begin{array}{l}+/-5 \% \text { band. Official pre-announced } \\
\text { crawling band around the US dollar, width } \\
\text { is }+/-7.5 \% \text {. }\end{array}$ \\
\hline & June 28, 1999-September 25, 1999 & $\begin{array}{l}\text { De facto crawling band around the } \\
\text { US dollar }\end{array}$ & $\begin{array}{l}+/-5 \% \text { band. There is an official } \\
\text { pre-announced crawling band around the } \\
\text { US dollar, which is }+/-10 \% \text {. Parallel }\end{array}$ \\
\hline & $\begin{array}{l}\text { September 25, 1999-December } \\
2010\end{array}$ & De facto band around the US dollar & $\begin{array}{l}\text { market premium remains below } 20 \% \text {. } \\
+/-5 \% \text { band. }\end{array}$ \\
\hline \multirow[t]{4}{*}{ Costa Rica } & $\begin{array}{l}\text { November 11, 1983-December } \\
1990\end{array}$ & $\begin{array}{l}\text { De facto crawling band around the } \\
\text { US dollar/Dual Market }\end{array}$ & $\begin{array}{l}\text { De facto }+/-5 \% \text { band, much narrower band } \\
\text { if official rate is used. }\end{array}$ \\
\hline & January 1991-December 2001 & $\begin{array}{l}\text { De facto crawling band around the } \\
\text { US dollar }\end{array}$ & $\begin{array}{l}\text { De facto }+/-2 \% \text { band. Parallel market } \\
\text { premium is in low single digits. De facto } \\
\text { crawling peg to US dollar since } 1995 \text { if } \\
\text { official rate is used. }\end{array}$ \\
\hline & January 2002-September 2006 & Crawling peg to the US dollar & \\
\hline & October 2006-April 2010 & De facto peg to the US dollar & \\
\hline \multirow[t]{3}{*}{ Croatia } & October 22, 1993-September 1994 & $\begin{array}{l}\text { Freely falling/Freely floating/Dual } \\
\text { Market }\end{array}$ & There is no price data before this date. \\
\hline & October 1994-January 1, 1999 & De facto band around the DM & $+/-2 \%$ band. \\
\hline & January 1, 1999-December 2010 & De facto band around the euro & $+/-2 \%$ band. \\
\hline \multirow[t]{4}{*}{ Cyprus } & July 9, 1973-March 1992 & $\begin{array}{l}\text { De facto crawling band around the } \\
\text { DM }\end{array}$ & $+/-2 \%$ band. \\
\hline & April 1992-January 1, 1999 & De facto peg to the DM & Officially there is a $+/-2.25 \%$ band. \\
\hline & January 1, 1999-December 2010 & De facto peg to the euro & $\begin{array}{l}\text { In January } 2001 \text {, it was announced that the } \\
\text { band would be widened to }+/-15 \% \text { to } \\
\text { become effective in August } 2001 \text {. Joined } \\
\text { the ERM II on May 2, 2005. Joined the } \\
\text { euro zone on January } 1,2008 \text {. }\end{array}$ \\
\hline & January 2008-December 2010 & Currency union & Euro. \\
\hline
\end{tabular}




\begin{tabular}{|c|c|c|c|}
\hline Country & Date & $\begin{array}{l}\text { Classification: } \\
\text { Primary/Secondary/Tertiary }\end{array}$ & Comments \\
\hline \multirow[t]{5}{*}{ Czech Republic } & September 1990-February 28, 1996 & $\begin{array}{l}\text { De facto crawling band around the } \\
\text { DM }\end{array}$ & $\begin{array}{l}+-2 \% \text { band. Officially tied to a currency } \\
\text { basket and then changed to the ECU. }\end{array}$ \\
\hline & February 28, 1996-May 27, 1997 & $\begin{array}{l}\text { De facto crawling band around the } \\
\text { DM }\end{array}$ & $\begin{array}{l}+/ 5-\% \text { band. Official pre-announced } \\
\text { crawling band around the DM is }+/-7.5 \% \text {. }\end{array}$ \\
\hline & May 27, 1997-December 1998 & $\begin{array}{l}\text { De facto crawling band around the } \\
\text { DM }\end{array}$ & $+/-2 \%$ band. \\
\hline & January 1999-December 2001 & De facto peg to the euro & \\
\hline & January 2002-December 2010 & $\begin{array}{l}\text { De facto crawling band around the } \\
\text { euro }\end{array}$ & $+/-5 \%$ band. \\
\hline \multirow[t]{2}{*}{ Denmark } & December 1978-January 1, 1999 & De Facto moving peg to the DM & \\
\hline & January 1, 1999-December 2010 & De facto peg to the euro & $\begin{array}{l}\text { Participant of ERM II. There is an official } \\
+/-2.25 \% \text { band. }\end{array}$ \\
\hline \multirow[t]{7}{*}{ Ecuador } & April 1987-September 1993 & Freely falling/Managed floating & $\begin{array}{l}\text { Parallel market premium hits } 150 \% \text { in } \\
1988 .\end{array}$ \\
\hline & October 1993-March 3, 1997 & $\begin{array}{l}\text { De facto crawling band around the } \\
\text { US dollar/Dual Market }\end{array}$ & $\begin{array}{l}+/-5 \% \text { band. Parallel market premium } \\
\text { declines into single digits during this } \\
\text { period. }\end{array}$ \\
\hline & March 3, 1997-September 1997 & $\begin{array}{l}\text { De facto crawling band around the } \\
\text { US dollar/Dual Market }\end{array}$ & $\begin{array}{l}\text { Pre-announced crawling band around the } \\
\text { US dollar, official band is }+/-5 \% \text {, the de } \\
\text { facto band is }+/-2 \% \text {. }\end{array}$ \\
\hline & October 1997- February 12, 1999 & $\begin{array}{l}\text { Freely falling/Pre-announced } \\
\text { crawling band around the US dollar. }\end{array}$ & $\begin{array}{l}\text { The official band is widened to }+/-10 \% \text { on } \\
\text { March } 25,1998 \text { and }+/-15 \% \text { on September } \\
14,1998 \text {. }\end{array}$ \\
\hline & February 12, 1999-March 13, 2000 & Freely falling/Freely floating & Markets are unified. \\
\hline & March 13, 2000-April 2001 & $\begin{array}{l}\text { Exchange rate arrangement with no } \\
\text { separate legal tender/Freely falling }\end{array}$ & US dollar. \\
\hline & May 2001-December 2010 & $\begin{array}{l}\text { Exchange rate arrangement with no } \\
\text { separate legal tender }\end{array}$ & US dollar. \\
\hline \multirow[t]{2}{*}{ Egypt } & July $25,1971-$ October 8,1991 & $\begin{array}{l}\text { De facto crawling band around the } \\
\text { US dollar/Multiple rates }\end{array}$ & $+/-5 \%$ band. \\
\hline & October 8, 1991-July 2010 & $\begin{array}{l}\text { De facto moving peg to the US } \\
\text { dollar/Multiple rates }\end{array}$ & $\begin{array}{l}\text { Parallel market premium is in single digits } \\
\text { through December } 1998 \text {, when the data } \\
\text { ends. Increased exchange rate variability }\end{array}$ \\
\hline
\end{tabular}




\begin{tabular}{|c|c|c|c|}
\hline Country & Date & $\begin{array}{l}\text { Classification: } \\
\text { Primary/Secondary/Tertiary }\end{array}$ & Comments \\
\hline & & & during May-November 2008. \\
\hline \multirow[t]{5}{*}{ Finland } & January 1973-September 8, 1992 & De facto band around the DM & $\begin{array}{l}+/-2 \% \text { band. Officially pegged to a basket } \\
\text { of currencies or the ECU during this } \\
\text { period. }\end{array}$ \\
\hline & September 8, 1992-March 1993 & Freely falling/Managed floating & ERM crisis. \\
\hline & April 1993-December 1994 & De facto moving band around the DM & $+/-2 \%$ band. \\
\hline & January 1995-January 1, 1999 & De facto peg to the DM & \\
\hline & January 1, 1999-December 2010 & Currency union & Euro. \\
\hline France & $\begin{array}{l}\text { January 1987-January 1, } 1999 \\
\text { January 1, 1999-December } 2010\end{array}$ & $\begin{array}{l}\text { De facto peg to the DM } \\
\text { Currency union }\end{array}$ & $\begin{array}{l}\text { Officially pegged to the ECU. } \\
\text { Euro. }\end{array}$ \\
\hline \multirow[t]{2}{*}{ Germany } & January 1973-January 1, 1999 & Float & \\
\hline & January 1, 1999-December 2010 & Currency Union & Euro. \\
\hline \multirow[t]{2}{*}{ Greece } & September 1989-January 1, 1999 & De facto peg to the DM & $\begin{array}{l}\text { On March } 15,1998, \text { the drachma entered } \\
\text { the ERM. }\end{array}$ \\
\hline & January 1, 1999-December 2010 & Currency union & Euro. \\
\hline \multirow[t]{5}{*}{ Hungary } & April 1, 1957-July 1, 1992 & $\begin{array}{l}\text { De Facto crawling band around the } \\
\text { DM/Multiple rates }\end{array}$ & $\begin{array}{l}+/-5 \% \text { band. Officially pegged to a basket } \\
\text { of currencies. On December } 1,1991 \text {, the } \\
\text { basket was changed to comprise the ECU } \\
\text { and the US dollar with equal weights. }\end{array}$ \\
\hline & July 1, 1992-May 16, 1994 & $\begin{array}{l}\text { De facto crawling band around the } \\
\text { DM }\end{array}$ & $\begin{array}{l}+/-5 \% \text { band. On August 2, 1993, the DM } \\
\text { replaced the ECU. }\end{array}$ \\
\hline & May 16, 1994-January 1, 1999 & $\begin{array}{l}\text { De facto crawling band around the } \\
\text { DM }\end{array}$ & $\begin{array}{l}+/-2 \% \text { band. At this time, the weight of the } \\
\text { DM in the basket was increased to } 70 \% \text {. }\end{array}$ \\
\hline & January 1, 1999-June 4, 2003 & $\begin{array}{l}\text { Pre-announced crawling band around } \\
\text { the euro }\end{array}$ & $+/-2.25 \%$ band \\
\hline & June 4, 2003-December 2010 & $\begin{array}{l}\text { Pre-announced crawling band around } \\
\text { the euro }\end{array}$ & $\begin{array}{l}+/-15 \% \text { band - the de facto band is }+/-5 \% \text {. } \\
\text { De facto peg to the euro during September } \\
2009-\text { February } 2010 \text {. }\end{array}$ \\
\hline Iceland & September 1986-October 2000 & $\begin{array}{l}\text { De facto crawling band around the } \\
\text { DM. }\end{array}$ & $\begin{array}{l}+/-2 \% \text { band. Officially pegged to a basket } \\
\text { of currencies. During this period, the } \\
\text { weight attached to the US dollar is } \\
\text { declining. On January 3,1992, the ECU } \\
\text { had a weight of } 76 \% \text {. }\end{array}$ \\
\hline
\end{tabular}




\begin{tabular}{|c|c|c|c|}
\hline Country & Date & $\begin{array}{l}\text { Classification: } \\
\text { Primary/Secondary/Tertiary }\end{array}$ & Comments \\
\hline & October 2000-March 28, 2001 & $\begin{array}{l}\text { De facto crawling band around the } \\
\text { DM/euro. }\end{array}$ & $\begin{array}{l}+/-5 \% \text { band. Officially pegged to a basket } \\
\text { of currencies. }\end{array}$ \\
\hline & March 28, 2001-March 2009 & $\begin{array}{l}\text { De facto crawling band around the } \\
\text { euro. }\end{array}$ & $+/-5 \%$ band. Officially inflation targeting. \\
\hline & March 2009-December 2010 & Managed floating. & \\
\hline \multirow[t]{4}{*}{ India } & August 1989-July 1991 & $\begin{array}{l}\text { De facto crawling peg to the US } \\
\text { dollar }\end{array}$ & \\
\hline & August 1991-June 1995 & De facto peg to the US dollar & $\begin{array}{l}\text { One devaluation in March } 1993 \text {-parallel } \\
\text { market premium rose to } 27 \% \text { in February. }\end{array}$ \\
\hline & July 1995-July 2005 & $\begin{array}{l}\text { De facto crawling peg to the US } \\
\text { dollar }\end{array}$ & $\begin{array}{l}\text { During this period, the parallel market } \\
\text { premium has been consistently in single } \\
\text { digits. }\end{array}$ \\
\hline & August 2005-December 2010 & $\begin{array}{l}\text { De facto crawling band around the } \\
\text { US dollar }\end{array}$ & $+/-2 \%$ band. \\
\hline \multirow[t]{3}{*}{ Indonesia } & November 16, 1978-July 1997 & $\begin{array}{l}\text { De facto crawling peg to the US } \\
\text { dollar }\end{array}$ & $\begin{array}{l}\text { Officially pegged to a basket of } \\
\text { undisclosed currencies. Premium } \\
\text { consistently below } 20 \% \text { and mostly in } \\
\text { single digits. }\end{array}$ \\
\hline & August 1997-March 1999 & Freely falling/Freely floating & $\begin{array}{l}\text { A dual rate comes into effect briefly in } \\
\text { February 1998, when a subsidized rate was } \\
\text { applied to certain food imports. }\end{array}$ \\
\hline & April 1999-December 2010 & $\begin{array}{l}\text { Managed floating/crawling band } \\
\text { around the US dollar }\end{array}$ & $+/-5 \%$ band. \\
\hline \multirow[t]{3}{*}{ Ireland } & March 30, 1979-October 1996 & De facto moving band around the DM & $+/-2 \%$ band. \\
\hline & November 1996-January 1, 1999 & De facto peg to the DM & \\
\hline & January 1, 1999-December 2010 & Currency union & Euro. \\
\hline \multirow[t]{3}{*}{ Israel } & January 3, 1989-March 1, 1990 & $\begin{array}{l}\text { Pre-announced crawling band around } \\
\text { the US dollar }\end{array}$ & $\begin{array}{l}\text { Official band is }+/-3 \% \text { but there is a de } \\
\text { facto band that is narrower, at }+/-2 \% \text {. }\end{array}$ \\
\hline & March 1, 1990-January 1991 & $\begin{array}{l}\text { De facto crawling band around the } \\
\text { US dollar }\end{array}$ & $\begin{array}{l}\text { Official band width is }+/-5 \% \text {, but de facto } \\
\text { band remains at }+/-2 \% \text {. }\end{array}$ \\
\hline & February 1991-December 2010 & $\begin{array}{l}\text { De facto crawling band around the } \\
\text { US dollar }\end{array}$ & $\begin{array}{l}\text { Officially, there is a pre-announced } \\
\text { crawling band around the US dollar. Since } \\
\text { July } 26,1993 \text {, the upper limit is } 6 \% \text {, and }\end{array}$ \\
\hline
\end{tabular}




\begin{tabular}{|c|c|c|c|}
\hline Country & Date & $\begin{array}{l}\text { Classification: } \\
\text { Primary/Secondary/Tertiary }\end{array}$ & Comments \\
\hline & & & $\begin{array}{l}\text { the lower limit is } 2 \% \text { since August } 6,1998 \text {. } \\
\text { Hence it is an ever widening band, which } \\
\text { was } 39.2 \% \text { as of December } 30,2000 \text {. } \\
\text { There is a de facto }+/-5 \% \text { band. }\end{array}$ \\
\hline \multirow[t]{6}{*}{ Italy } & January 1983-September 13,1992 & $\begin{array}{l}\text { De facto crawling band around the } \\
\text { DM }\end{array}$ & $+/-2 \%$ band. \\
\hline & September 13, 1992-March 1993 & Freely falling & \\
\hline & April 1993-July 1995 & $\begin{array}{l}\text { De facto crawling band around the } \\
\text { DM }\end{array}$ & $+/-2 \%$ band. \\
\hline & August 1995-November 1996 & De facto crawling peg to the DM & \\
\hline & December 1996-January 1, 1999 & De facto peg to the DM & \\
\hline & January 1, 1999-December 2010 & Currency union & Euro. \\
\hline Japan & December 1977-December 2010 & Freely floating & \\
\hline \multirow[t]{8}{*}{ Korea, Rep. of } & March 2, 1990-September 2, 1991 & $\begin{array}{l}\text { Pre-announced crawling band around } \\
\text { the US dollar }\end{array}$ & $\begin{array}{l}+/-0.4 \% \text { band. This fits into our definition } \\
\text { of crawling peg. }\end{array}$ \\
\hline & September 2, 1991-July 1, 1992 & $\begin{array}{l}\text { Pre-announced crawling band around } \\
\text { the US dollar }\end{array}$ & $\begin{array}{l}+/-0.6 \% \text { band. This fits into our definition } \\
\text { of crawling peg. }\end{array}$ \\
\hline & July 1, 1992-October 1, 1993 & $\begin{array}{l}\text { Pre-announced crawling band around } \\
\text { the US dollar }\end{array}$ & $\begin{array}{l}+/-0.8 \% \text { band. This fits into our definition } \\
\text { of crawling peg. }\end{array}$ \\
\hline & October 1, 1993-November 1, 1994 & $\begin{array}{l}\text { Pre-announced crawling band around } \\
\text { the US dollar }\end{array}$ & $\begin{array}{l}+/-1 \% \text { band. This fits into our definition of } \\
\text { crawling peg. }\end{array}$ \\
\hline & $\begin{array}{l}\text { November 1, 1994-December 1, } \\
1995\end{array}$ & $\begin{array}{l}\text { De facto crawling peg to the US } \\
\text { dollar }\end{array}$ & Pre-announced band is $+/-1.5 \%$ \\
\hline & December 1, 1995-November 1997 & $\begin{array}{l}\text { De facto crawling peg to the US } \\
\text { dollar }\end{array}$ & $\begin{array}{l}\text { Officially, the pre-announced band is }+/- \\
2.25 \% \text {. }\end{array}$ \\
\hline & December 17, 1997-June 1998 & Freely falling & The won was allowed to float. \\
\hline & July 1998-December 2010 & Managed floating & \\
\hline \multirow[t]{3}{*}{ Latvia } & January 1991-January 1994 & Freely falling/Managed floating & $\begin{array}{l}\text { There is no price data before this date. On } \\
\text { July } 20,1992 \text {, the Latvian ruble replaced } \\
\text { the Russian ruble. On October } 19,1993 \text {, } \\
\text { the Latvian lats became sole legal tender. }\end{array}$ \\
\hline & February 1994-August 1994 & Peg to SDR/Freely falling & \\
\hline & September 1994-August 2001 & De facto crawling band around the & $+/-5 \%$ band. Official peg to SDR. \\
\hline
\end{tabular}




\begin{tabular}{|c|c|c|c|}
\hline Country & Date & $\begin{array}{l}\text { Classification: } \\
\text { Primary/Secondary/Tertiary }\end{array}$ & Comments \\
\hline & & US dollar & \\
\hline & $\begin{array}{l}\text { September 2001-December 29, } \\
2004\end{array}$ & $\begin{array}{l}\text { De facto crawling band around the } \\
\text { euro }\end{array}$ & $+/-2 \%$ band. \\
\hline & December 30, 2004-December & De jure peg to the euro & Joined the ERM II on May 2, 2005. \\
\hline & 2010 & & $\begin{array}{l}\text { Starting December } 30,2004 \text {, the lats was } \\
\text { pegged to the euro with a }+/-1 \% \text { band. De } \\
\text { facto, the band has been }+/-2 \% \text { until June } \\
2009 \text { when the de facto peg to the euro was } \\
\text { introduced. }\end{array}$ \\
\hline \multirow[t]{5}{*}{ Lithuania } & January 1991-June 25, 1993 & Freely falling/Managed floating & $\begin{array}{l}\text { On May 1, 1992, the talonas was } \\
\text { introduced as legal tender. }\end{array}$ \\
\hline & June 25, 1993-April 1, 1994 & Freely falling/Managed floating & $\begin{array}{l}\text { The litas was introduced to replace the } \\
\text { temporary talonas and on July } 20 \text { became } \\
\text { sole legal tender. }\end{array}$ \\
\hline & April 1, 1994-April 1995 & Peg to the US dollar/Freely falling & Currency board was introduced. \\
\hline & May 1995-February 1, 2002 & Peg to the US dollar & Currency board. \\
\hline & February 2, 2002-December 2010 & De facto band around the euro & $\begin{array}{l}\text { Band is }+/-2 \% \text {. Joined ERM II on June } 28 \text {, } \\
2004 \text {. En route to joining the euro zone in } \\
2010 \text {. }\end{array}$ \\
\hline \multirow[t]{3}{*}{ Luxembourg } & July 18, 1955-March 5, 1990 & De facto peg to the DM/Dual Market & Small parallel market premium. \\
\hline & March 5, 1990-December 31, 1991 & De facto peg to the DM & \\
\hline & January 1, 1999-December 2010 & Currency union & Euro. \\
\hline \multirow[t]{4}{*}{ Malaysia } & September 5, 1975-July 1997 & $\begin{array}{l}\text { De facto moving band around the US } \\
\text { dollar }\end{array}$ & $\begin{array}{l}\text { Band is }+/-2 \% \text {. Officially, the ringgit is } \\
\text { pegged to a basket of currencies. }\end{array}$ \\
\hline & August 1997-September 30, 1998 & Freely floating & \\
\hline & September 30, 1998-June 2005 & Peg to the US dollar & \\
\hline & July 2005-December 2010 & De facto band around the US dollar & $\begin{array}{l}+/-2 \% \text { band. Officially, it is a managed } \\
\text { float against an undisclosed basket of } \\
\text { currencies. }\end{array}$ \\
\hline \multirow[t]{2}{*}{ Malta } & 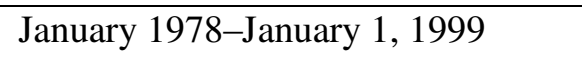 & Moving band around the DM & \\
\hline & January 1, 1999-December 2000 & Moving band around the euro & $+/-2 \%$ band. \\
\hline
\end{tabular}




\begin{tabular}{|c|c|c|c|}
\hline Country & Date & $\begin{array}{l}\text { Classification: } \\
\text { Primary/Secondary/Tertiary }\end{array}$ & Comments \\
\hline & January 2001-December 2010 & De facto crawling peg to the euro & $\begin{array}{l}\text { Joined the ERM II on May 2, 2005. Joined } \\
\text { the euro zone on January 1, } 2008 .\end{array}$ \\
\hline \multirow[t]{6}{*}{ Mexico } & $\begin{array}{l}\text { December 1988-November 11, } \\
1991\end{array}$ & Crawling Peg/Dual Market & \\
\hline & November 11, 1991-April 1992 & $\begin{array}{l}\text { De facto crawling peg to the US } \\
\text { dollar }\end{array}$ & $\begin{array}{l}\text { The rates were unified in November } 1991 \text {. } \\
\text { The official arrangement was an ever } \\
\text { widening crawling band (see below). }\end{array}$ \\
\hline & May 1992-January 1994 & De facto peg to the US dollar & $\begin{array}{l}\text { Officially there is a band. The annualized } \\
\text { rate of crawl of the upper limit of the band } \\
\text { is } 2.4 \% \text { through October } 20,1992 \text {, and } \\
4.7 \% \text { through June } 30,1993 \text {. }\end{array}$ \\
\hline & February 1994-December 22, 1994 & $\begin{array}{l}\text { Pre-announced crawling band around } \\
\text { the US dollar }\end{array}$ & Pre-announced band becomes binding. \\
\hline & December 22, 1994-March 1996 & Freely falling/Freely floating & $\begin{array}{l}\text { In December 1994, the parallel market } \\
\text { premium jumped to } 27 \% \text { from single } \\
\text { digits. }\end{array}$ \\
\hline & April 1996-December 2010 & Managed float/de facto crawling band & $\begin{array}{l}+/-5 \% \text { band }(98 \% \text { of the observations are } \\
\text { within the band). Significant depreciation } \\
\text { in October } 2008 .\end{array}$ \\
\hline \multirow[t]{2}{*}{ Netherlands } & March 1983-January 1, 1999 & De facto peg around the DM & $\begin{array}{l}\text { One currency crash versus the US dollar on } \\
\text { March 1991, none versus the DM. }\end{array}$ \\
\hline & January 1, 1999-December 2010 & Currency union & Euro. \\
\hline New Zealand & March 4, 1985-December 2010 & Managed floating & \\
\hline \multirow[t]{2}{*}{ Norway } & July 1987-December 10, 1992 & Moving band around the DM & $\begin{array}{l}+/-2 \% \text { band. December } 1992 \text { does not } \\
\text { register as a currency crash. }\end{array}$ \\
\hline & $\begin{array}{l}\text { December 10, 1992-December } \\
2010\end{array}$ & $\begin{array}{l}\text { Managed floating/de facto band } \\
\text { around the euro }\end{array}$ & $+/-5 \%$ band \\
\hline \multirow[t]{2}{*}{ Pakistan } & September 1989-April 1991 & De facto crawling peg/Parallel Market & \\
\hline & May 1991-April 1994 & $\begin{array}{l}\text { De facto crawling band around the } \\
\text { US dollar/Parallel Market }\end{array}$ & $\begin{array}{l}\text { Band width is }+/-2 \% \text {. If the parallel rate is } \\
\text { used, the band width is }+/-5 \% \text {. From } \\
\text { August } 1993 \text { through May } 1998 \text {, the } \\
\text { parallel market premium is in single digits. } \\
\text { A more precise description of the }\end{array}$ \\
\hline
\end{tabular}




\begin{tabular}{|c|c|c|c|}
\hline Country & Date & $\begin{array}{l}\text { Classification: } \\
\text { Primary/Secondary/Tertiary }\end{array}$ & Comments \\
\hline & & & $\begin{array}{l}\text { post-November } 1996 \text { period is mini pegs } \\
\text { lasting a few moths interspersed with a } \\
\text { regular devaluation. }\end{array}$ \\
\hline & July 22, 1998-May 19, 1999 & $\begin{array}{l}\text { De facto crawling band/Dual Market/ } \\
\text { Multiple exchange rates }\end{array}$ & $\begin{array}{l}\text { Band width is }+/-2 \% \text { (on the basis of the } \\
\text { parallel market rate). }\end{array}$ \\
\hline & May 19, 1999-February 2008 & $\begin{array}{l}\text { De facto crawling peg to the US } \\
\text { dollar/Parallel Market }\end{array}$ & \\
\hline & August 2008-December 2010 & $\begin{array}{l}\text { De facto crawling band around the } \\
\text { US dollar }\end{array}$ & $\begin{array}{l}\text { Band width is }+/-2 \% \text {, following a freely } \\
\text { falling episode from March-July } 2008 \text {. }\end{array}$ \\
\hline \multirow[t]{4}{*}{ Peru } & December 2, 1986-August 9, 1990 & Freely falling/Freely floating/ & Parallel market premium hits $1,067 \%$ in \\
\hline & & Multiple exchange rates & $\begin{array}{l}\text { August } 1988 \text {-September } 1988 \text { classifies } \\
\text { as a "hyperfloat." The } 12 \text {-month rate of } \\
\text { inflation reaches } 12,378 \% \text {. }\end{array}$ \\
\hline & August 9, 1990-November 1993 & Freely falling/Freely floating & Unification of rates. \\
\hline & November 1993-December 2010 & $\begin{array}{l}\text { De facto crawling band around the } \\
\text { US dollar }\end{array}$ & $\begin{array}{l}+/-2 \% \text { band. Parallel market premium in } \\
\text { single digits. Officially began inflation } \\
\text { targeting on January } 1,2003 \text {. De facto peg } \\
\text { starting in October } 2009 .\end{array}$ \\
\hline \multirow[t]{7}{*}{ Philippines } & March 1985-April 1992 & $\begin{array}{l}\text { De facto crawling peg to the US } \\
\text { dollar }\end{array}$ & \\
\hline & May 1992-April 1993 & De facto band around the US dollar & $+/-2 \%$ band. \\
\hline & May 1993-August 1995 & De facto band around the US dollar & $+/-5 \%$ band. \\
\hline & September 1995-June 1997 & De facto peg to the US dollar & \\
\hline & July 1997-December 1997 & Freely falling/Freely floating & $\begin{array}{l}\text { Parallel market premium peaked at } 17 \% \text { on } \\
\text { July } 1997 .\end{array}$ \\
\hline & December 1997-November 1999 & Managed floating & \\
\hline & December 1999-December 2007 & $\begin{array}{l}\text { De facto crawling band around the } \\
\text { US dollar }\end{array}$ & $\begin{array}{l}+/-2 \% \text { band. Band appears to have } \\
\text { broadened to }+/-5 \% \text { since October } 2007 \text {. }\end{array}$ \\
\hline \multirow[t]{4}{*}{ Poland } & March 15, 1989-January 1, 1990 & $\begin{array}{l}\text { Freely falling/ Freely floating/Dual } \\
\text { Market }\end{array}$ & Parallel market is legalized. \\
\hline & January 1, 1990-May 17, 1991 & Freely falling/Dual Market & Official rate is pegged to the US dollar. \\
\hline & May 17, 1991-April 1993 & Freely falling/Dual Market & $\begin{array}{l}\text { Official rate is set as a pre-announced } \\
\text { crawling peg to the US dollar. }\end{array}$ \\
\hline & May 1993-May 16, 1995 & Dual Market & Official rate is set as a pre-announced \\
\hline
\end{tabular}




\begin{tabular}{|c|c|c|c|}
\hline Country & Date & $\begin{array}{l}\text { Classification: } \\
\text { Primary/Secondary/Tertiary }\end{array}$ & Comments \\
\hline & May 16, 1995-February, 251998 & $\begin{array}{l}\text { De facto crawling band around the } \\
\text { euro }\end{array}$ & $\begin{array}{l}\text { crawling peg to the US dollar. There is no } \\
\text { parallel market data for this period. } \\
+/-5 \% \text { band. There is a pre-announced } \\
\text { crawling band around the DM and US } \\
\text { dollar that is }+/-7 \% \text {. }\end{array}$ \\
\hline & $\begin{array}{l}\text { February 25, 1998-October 29, } \\
1998\end{array}$ & $\begin{array}{l}\text { De facto crawling band around the } \\
\text { euro }\end{array}$ & $\begin{array}{l}+/-5 \% \text { band. There is a pre-announced } \\
\text { crawling band around the DM and US } \\
\text { dollar that is }+/-10 \% \text {. }\end{array}$ \\
\hline & October 29, 1998-March 24, 1999 & $\begin{array}{l}\text { De facto crawling band around the } \\
\text { DM/euro }\end{array}$ & $\begin{array}{l}+/-5 \% \text { band. There is a pre-announced } \\
\text { crawling band around the DM and US } \\
\text { dollar that is }+/-12.5 \% \text {. }\end{array}$ \\
\hline & March 24, 1999-April 12, 2000 & $\begin{array}{l}\text { De facto crawling band around the } \\
\text { euro }\end{array}$ & $\begin{array}{l}+/-5 \% \text { band. There is a pre-announced } \\
\text { crawling band around the DM and US } \\
\text { dollar that is }+/-15 \% \text {. }\end{array}$ \\
\hline & April 12, 2000-December 2010 & $\begin{array}{l}\text { Managed floating/de facto band } \\
\text { around the euro }\end{array}$ & $\begin{array}{l}+-5 \% \text { band. Fluctuations have remained } \\
\text { consistently inside this band at least } 95 \% \\
\text { of the time. Significant depreciation during } \\
2008 \mathrm{Q} 4 \text { to } 2009 \mathrm{Q} 1 \text {. }\end{array}$ \\
\hline \multirow[t]{4}{*}{ Portugal } & March 1981-August 1993 & $\begin{array}{l}\text { De facto crawling band around the } \\
\text { DM }\end{array}$ & $+/-2 \%$ band. \\
\hline & September 1992-June 1993 & De facto crawling peg to the DM & \\
\hline & July 1993-January 1, 1999 & De facto peg to the DM & \\
\hline & January 1, 1999-December 2010 & Currency union & Euro. \\
\hline \multirow[t]{4}{*}{ Romania } & July 1957-January 1990 & Dual Market/Multiple exchange rates & $\begin{array}{l}25 \text { rates were applied to exports alone. On } \\
\text { July } 1,1983 \text { the number of rates was } \\
\text { reduced to two. }\end{array}$ \\
\hline & February 1990-November 11, 1991 & $\begin{array}{l}\text { Freely falling/Freely floating/Dual } \\
\text { Market }\end{array}$ & $\begin{array}{l}\text { CPI data available only from October } \\
1989 .\end{array}$ \\
\hline & November 11, 1991-March 2001 & Freely falling/Freely floating & \\
\hline & April 2001-December 2010 & $\begin{array}{l}\text { Managed float/De facto band around } \\
\text { the euro. }\end{array}$ & $\begin{array}{l}+/-5 \% \text { band. August } 2005 \text { marks the } \\
\text { beginning of inflation targeting. Since } \\
\text { then, the exchange rate has remained } \\
\text { within a } 5 \% \text { band around the euro ( } 90 \% \text { of } \\
\text { the observations). Until adoption of }\end{array}$ \\
\hline
\end{tabular}




\begin{tabular}{|c|c|c|c|}
\hline Country & Date & $\begin{array}{l}\text { Classification: } \\
\text { Primary/Secondary/Tertiary }\end{array}$ & Comments \\
\hline & & & $\begin{array}{l}\text { inflation targeting, currency shadows the } \\
\text { US dollar more closely than the euro. }\end{array}$ \\
\hline \multirow{5}{*}{$\begin{array}{l}\text { Russian } \\
\text { Federation }\end{array}$} & January 1992-June 1, 1995 & Freely falling/Dual Market & There is no price data before this date. \\
\hline & July 6, 1995-July 1996 & Freely falling/Dual Market & $\begin{array}{l}\text { Pre-announced crawling band around the } \\
\text { US dollar for the official rate. }\end{array}$ \\
\hline & August 1996-August 17, 1998 & Dual Market & $\begin{array}{l}\text { Pre-announced crawling band around the } \\
\text { US dollar for the official rate. }\end{array}$ \\
\hline & August 17, 1998-November 1999 & Freely falling/Dual Market & $\begin{array}{l}\text { The band was widened on August } 17 \text { and } \\
\text { eliminated on September } 2 \text {. On June 29, } \\
\text { 1999, the two rates are unified temporarily. }\end{array}$ \\
\hline & December 1999-December 2010 & $\begin{array}{l}\text { De facto crawling band around the } \\
\text { US dollar/Multiple exchange rates }\end{array}$ & $\begin{array}{l}\text { Band width is }+/-2 \% \text {. In principle, it } \\
\text { targets a US dollar-euro basket. Band } \\
\text { appears to widen to }+/-5 \% \text { starting } \\
\text { October } 2009 \text {. }\end{array}$ \\
\hline $\begin{array}{l}\text { Serbia \& } \\
\text { Montenegro }\end{array}$ & November 2001-December 2010 & $\begin{array}{l}\text { Managed float/De facto band around } \\
\text { the euro }\end{array}$ & $\begin{array}{l}+-5 \% \text { band. Montenegro uses the euro as } \\
\text { legal tender. Significant devaluation in } \\
\text { October } 2008-\text { January } 2009 .\end{array}$ \\
\hline Singapore & June 21, 1973-December 2010 & $\begin{array}{l}\text { De facto moving band around the US } \\
\text { dollar }\end{array}$ & $\begin{array}{l}+/-2 \% \text { band. Officially adjusted on the } \\
\text { basis of a basket of currencies. }\end{array}$ \\
\hline \multirow{6}{*}{ Slovak Republic } & February 8, 1993-March 1993 & Freely falling & The Slovak koruna is introduced. \\
\hline & April 1993-July 31,1996 & $\begin{array}{l}\text { De facto crawling band around the } \\
\text { DM }\end{array}$ & Band width is $+/-2 \%$ \\
\hline & July 31, 1996-January 1, 1997 & & $\begin{array}{l}+/-2 \% \text { band. Pre-announced crawling band } \\
\text { is }+/-5 \% \text {. The official basket also includes } \\
\text { the US dollar with a lower weight than the } \\
\text { DM. }\end{array}$ \\
\hline & January 1, 1997-September 1997 & $\begin{array}{l}\text { De facto crawling band around the } \\
\text { DM }\end{array}$ & $\begin{array}{l}+/-2 \% \text { band. Pre-announced crawling band } \\
\text { is }+/-7 \% \text {. }\end{array}$ \\
\hline & September 1997-October 1, 1998 & $\begin{array}{l}\text { De facto crawling band around the } \\
\text { DM }\end{array}$ & $\begin{array}{l}+/-5 \% \text { band. Pre-announced crawling band } \\
\text { is }+/-7 \% \text {. }\end{array}$ \\
\hline & October 1, 1998-December 2008 & $\begin{array}{l}\text { De facto crawling band around the } \\
\text { DM, then the euro }\end{array}$ & $\begin{array}{l}+/-2 \% \text { band. The official band is }+/-15 \% \text {. } \\
\text { Joined the ERM II on November } 25,2005 \text {. }\end{array}$ \\
\hline
\end{tabular}




\begin{tabular}{|c|c|c|c|}
\hline Country & Date & $\begin{array}{l}\text { Classification: } \\
\text { Primary/Secondary/Tertiary }\end{array}$ & Comments \\
\hline & January 2009-December 2010 & Currency union & Euro. \\
\hline \multirow[t]{6}{*}{ Slovenia } & October 1991-February 1992 & Freely falling & $\begin{array}{l}\text { There is no price data before this date. The } \\
\text { tolar is introduced to replace the Yugoslav } \\
\text { dinar. }\end{array}$ \\
\hline & March 1992-March 1993 & $\begin{array}{l}\text { Freely falling/De facto crawling band } \\
\text { around the DM }\end{array}$ & $+/-2 \%$ band. \\
\hline & April 1993-January 1, 1999 & $\begin{array}{l}\text { De facto crawling band around the } \\
\text { DM }\end{array}$ & $+/-2 \%$ band. \\
\hline & January 1, 1999-August 2001 & $\begin{array}{l}\text { De facto crawling band around the } \\
\text { euro }\end{array}$ & $+/-2 \%$ band. \\
\hline & September 2001-December 2006 & Peg to the euro & $\begin{array}{l}\text { Joined ERM II on June } 28,2004 \text {. De facto } \\
\text { crawling band around the euro until } \\
\text { December } 2003 \text {. }\end{array}$ \\
\hline & January 1, 2007-December 2010 & Currency union & Euro. \\
\hline \multirow[t]{2}{*}{ South Africa } & September 2, 1985-March 13, 1995 & Dual Rate/Managed floating & $\begin{array}{l}\text { There are several spikes in the premium } \\
\text { including in } 1985 \text { and } 1987 \text {, when the } \\
\text { premium approached } 40 \% \text {. }\end{array}$ \\
\hline & March 13, 1995-December 2010 & Freely floating & \\
\hline \multirow[t]{3}{*}{ Spain } & January 1981-April 1994 & $\begin{array}{l}\text { De facto crawling band around the } \\
\text { DM }\end{array}$ & $+/-2 \%$ band. \\
\hline & May 1994-January 1, 1999 & De facto peg to the DM & \\
\hline & January 1, 1999-December 2010 & Currency union & Euro. \\
\hline \multirow[t]{3}{*}{ Sweden } & $\begin{array}{l}\text { March 19, 1973-November 19, } \\
1992\end{array}$ & $\begin{array}{l}\text { De facto crawling band around the } \\
\text { DM }\end{array}$ & $+/-2 \%$ band. \\
\hline & November 19, 1992-January 1999 & Managed floating & Inflation targeting begins in 1993. \\
\hline & February 1999-December 2010 & $\begin{array}{l}\text { Managed floating/De facto moving } \\
\text { band around the euro }\end{array}$ & $+/-5 \%$ band \\
\hline \multirow[t]{2}{*}{ Switzerland } & September 1981-December 1998 & De facto moving band around the DM & $+/-2 \%$ band. \\
\hline & January 1999-December 2010 & $\begin{array}{l}\text { De facto moving band around the } \\
\text { euro }\end{array}$ & $+/-2 \%$ band. \\
\hline Thailand & March 8, 1978-July 1997 & De facto peg to the US dollar & $\begin{array}{l}\text { The baht is officially pegged to a basket of } \\
\text { currencies. }\end{array}$ \\
\hline
\end{tabular}




\begin{tabular}{|c|c|c|c|}
\hline Country & Date & $\begin{array}{l}\text { Classification: } \\
\text { Primary/Secondary/Tertiary }\end{array}$ & Comments \\
\hline & July 1997-January 1998 & Freely falling/Freely floating & \\
\hline & January 1998-September 1999 & Managed floating & \\
\hline & October 1999-December 2010 & $\begin{array}{l}\text { De facto moving band around the US } \\
\text { dollar }\end{array}$ & $\begin{array}{l}+/-2 \% \text { band. Inflation targeting since May } \\
2000 \text {. }\end{array}$ \\
\hline \multirow[t]{6}{*}{ Turkey } & May 1984-January 1998 & Freely falling/Managed floating & \\
\hline & February 1998-January 1, 1999 & $\begin{array}{l}\text { Crawling band around the DM/Freely } \\
\text { falling }\end{array}$ & $\begin{array}{l}+-5 \% \text { band. The crawling band is only } \\
\text { detected with the } 24-\text { month window. }\end{array}$ \\
\hline & January 1, 1999-January 2001 & $\begin{array}{l}\text { Crawling band around the euro/Freely } \\
\text { falling }\end{array}$ & $+/-5 \%$ band \\
\hline & February 2001-March 2003 & Freely falling/Freely floating & \\
\hline & April 2003-July 2007 & Freely floating & \\
\hline & August 2007-December 2010 & $\begin{array}{l}\text { Managed floating/De facto band } \\
\text { around the US dollar }\end{array}$ & $\begin{array}{l}\text { Band is }+/-5 \% \text {. Significant depreciation in } \\
\text { October } 2008 \text {, accompanied by annualized } \\
\text { inflation nearing } 40 \% \text {. }\end{array}$ \\
\hline \multirow[t]{5}{*}{$\begin{array}{l}\text { United } \\
\text { Kingdom }\end{array}$} & June 23, 1972-October 8, 1990 & Managed floating & $\begin{array}{l}\text { Until the dissolution of the Sterling Area } \\
\text { on October } 24,1979 \text { and the dismantling } \\
\text { of capital controls, the UK had a dual rate } \\
\text { system. }\end{array}$ \\
\hline & $\begin{array}{l}\text { October 8, 1990-September 12, } \\
1992\end{array}$ & $\begin{array}{l}\text { Pre-announced band around the } \\
\text { ECU/DM }\end{array}$ & $+/-6 \%$ band. \\
\hline & $\begin{array}{l}\text { September 12, 1992-December } \\
2001\end{array}$ & Managed floating & \\
\hline & January 2001-December 2008 & $\begin{array}{l}\text { De facto moving band around the } \\
\text { euro }\end{array}$ & $+/-2 \%$ band. \\
\hline & January 2009-December 2010 & Managed floating & \\
\hline United States & February 13, 1973-December 2010 & Freely floating & $\begin{array}{l}\text { Further devaluation versus gold and other } \\
\text { currencies. On April 1, } 1978 \text { the law that } \\
\text { required the par value of the US dollar in } \\
\text { terms of gold and SDRs is repealed. }\end{array}$ \\
\hline
\end{tabular}


Table A4 Exchange rate arrangements in AREAER pre-2008 and post-2008

\begin{tabular}{cll}
\hline Category & \multicolumn{1}{c}{ Pre-2008 } & \multicolumn{1}{c}{ Post-2008 } \\
\hline 1 & $\begin{array}{l}\text { Exchange arrangement with no separate legal } \\
\text { tender }\end{array}$ & No separate legal tender \\
2 & Currency board arrangements & Currency board \\
3 & Other conventional fixed peg arrangements & $\begin{array}{l}\text { Conventional peg } \\
\text { Stabilized arrangement }\end{array}$ \\
4 & Pegged exchange rates within horizontal & \\
& bands & Crawling peg \\
5 & Crawling pegs & Crawl-like arrangement \\
6 & Crawling bands & Pegged exchange rate within \\
7 & Managed floating with no pre-determined & horizontal bands \\
& path for the exchange rate & Other managed arrangement \\
9 & Independently floating & Floating \\
10 & - & Free floating \\
\hline
\end{tabular}


Table A5: Using long-term government bond yield as dependent variable (M1 1999 to M3 2009)

\begin{tabular}{|c|c|c|}
\hline & $\begin{array}{l}\text { Using long-term } \\
\text { government bond yield as } \\
\text { dependent variable } \\
\text { (1) }\end{array}$ & $\begin{array}{c}\text { Robustness check: Using policy rate } \\
\text { changes as dependent variable with the } \\
\text { same country-episodes as long-term bond } \\
\text { yield } \\
(2)\end{array}$ \\
\hline$i_{i, t-1}^{L}$ & $\begin{array}{c}-\mathbf{0 . 0 6 8 *} \\
(0.02)\end{array}$ & $\begin{array}{c}-\mathbf{0 . 1 1 1 *} \\
(0.02)\end{array}$ \\
\hline$\Delta G D P$ growth $_{i, t}$ & $\begin{array}{c}\mathbf{0 . 0 6 4 *} \\
(0.03)\end{array}$ & $\begin{array}{c}\mathbf{0 . 1 2 2} * \\
(0.04)\end{array}$ \\
\hline$\Delta$ Inflation $_{i, t}$ & $\begin{array}{c}\mathbf{0 . 1 6 2 *} \\
(0.05)\end{array}$ & $\begin{array}{l}\mathbf{0 . 3 7 *} \\
(0.05)\end{array}$ \\
\hline$D_{\text {fixed.NC }} \Delta r_{i, t}^{U S}$ & $\begin{array}{l}\mathbf{0 . 6 8 0 *} \\
(0.31)\end{array}$ & $\begin{array}{l}\mathbf{0 . 6 0 3 *} \\
(0.20)\end{array}$ \\
\hline$D_{\text {fixed.C }} \Delta r_{i, t}^{U S}$ & $\begin{array}{c}0.34 \\
(0.52)\end{array}$ & $\begin{array}{c}0.09 \\
(0.23)\end{array}$ \\
\hline$D_{\text {flex.NC }} \Delta r_{i, t}^{U S}$ & $\begin{array}{c}\mathbf{0 . 4 0 7 *} \\
(0.13)\end{array}$ & $\begin{array}{c}\mathbf{0 . 3 5 2} * \\
(0.08)\end{array}$ \\
\hline$D_{\text {flex.C }} \Delta r_{i, t}^{U S}$ & $\begin{array}{c}0.12 \\
(0.13)\end{array}$ & $\begin{array}{c}0.13 \\
(0.08)\end{array}$ \\
\hline$\Delta V I X_{t}$ & $\begin{array}{c}0.14 \\
(0.10)\end{array}$ & $\begin{array}{c}0.06 \\
(0.11)\end{array}$ \\
\hline $\begin{array}{l}\text { Adjusted R-squared } \\
\text { No. of Obs. }\end{array}$ & $\begin{array}{l}0.20 \\
301\end{array}$ & $\begin{array}{l}0.41 \\
301\end{array}$ \\
\hline
\end{tabular}

Figure A1

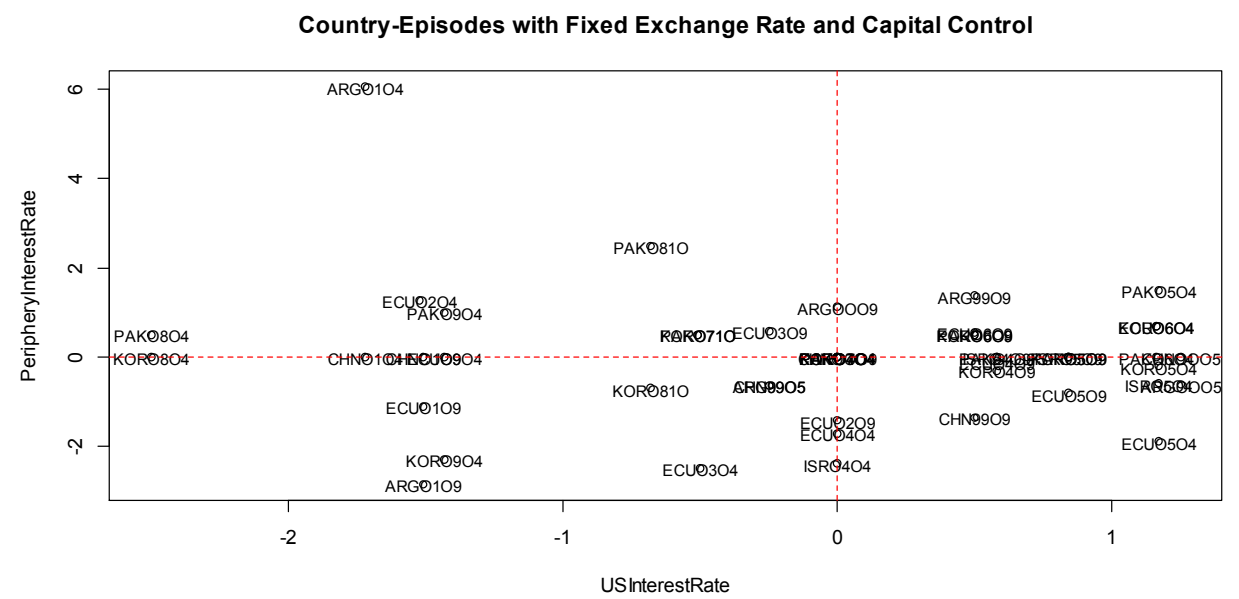

Argentina April 2001 appears to be outlier, and is responsible for the negative coefficient, $\beta_{2}=$ -0.249 in column (3) of Table 3 . In subsequent regressions, we remove this observation. 